FACULTAD DE CIENCIAS VETERINARIAS

UNIVERSIDAD NACIONAL DE LA PLATA

\title{
Estudio de asociación mediante marcadores genéticos de la Queratitis Superficial Crónica en perros de raza Ovejero Alemán
}

\section{Laura Soledad Barrientos}

Trabajo de tesis para ser presentado como requisito parcial para optar al Título de DOCTORA en CIENCIAS VETERINARIAS

\author{
Área Genética de Animales Domésticos \\ PROGRAMA DE POSGRADO EN CIENCIAS VETERINARIAS
}

Director: Guillermo Giovambattista

Codirectora: Pilar Peral Garcia

Miembros del jurado:

-Marcela Juliarena

-Gastón More

-Sebastian Picco 
Dedicado especialmente a mi hermana, Mariel. 


\section{Agradecimientos}

En este apartado, quisiera agradecer a quienes hicieron posible este trabajo de tesis. A todos los miembros de mi querida Facultad de Ciencias Veterinarias de la UNLP, en donde obtuve mi título de grado y viví las mejores etapas de mi vida, por brindarme el lugar de trabajo.

A mi director, Guillermo Giovambattista, por su constante ayuda, preocupación y buen humor en el desarrollo de mi trabajo.

A mi codirectora y directora del IGEVET, Pilar Peral García, por tener siempre tan buena predisposición para atender mis necesidades, tanto laborales como personales.

A todos y cada uno de los miembros del IGEVET.

A Diego Posik por su gran ayuda en la secuenciación de los genes DLA y por estar siempre dispuesto a evacuar cualquier duda.

A Hernan Olivera por el desarrollo del software para asignación de genotipos, por los mates y la buena onda, siempre.

A Juan Pedro Lirón por la ayuda con los análisis de asociación y por las miles de charlas. A Julian Crespi por ser tan buen compañero y ayudarme siempre (Gracias Man).

A Egle Villegas Castagnasso por las risas y por las buenas conversaciones.

A Andres Rogberg Muñoz por siempre tener la buena predisposición para ayudar y aconsejar.

A todos los que en este trayecto se convirtieron en amigos a los que quiero mucho: Agustin Falomir, Claudia Corbi Botto, Daniel Goszczynski, Elisa Cordoba, Hernan Morales, Maria Elena Fernandez, María Eugenia Zappa, Nadia Castillo y Suani Pacheco Marino.

A Veronica It por haberme iniciado en la actividad del laboratorio y en la genética de caninos.

A Gustavo Zapata y Agustina Iaquinandi, por la colaboración en la obtención de muestras y en la realización de la inspección oftalmológica de los pacientes incluidos en el trabajo.

A mi hermana de la vida, Marina Li Rosi por estar siempre y haberme dado una ahijada hermosa.

A mis grandes amigas, Natalia Eguren, Sabrina Micale, Mariana Villalba y Natalia Gonzalez.

A toda mi familia, en especial a mi hermanita, por quererme tanto. 
Al Estado Argentino por la educación pública y por el Consejo Nacional de Investigaciones Científicas y Técnicas (CONICET). 
Publicación parcial del trabajo de tesis

- Barrientos, L; Zapata, G; Crespi, J; Posik, D; Díaz, S; It, V; Peral-García, P; Giovambattista , G. 2013. A study of the association between chronic superficial keratitis and polymorphisms in the upstream regulatory regions of DLA-DRB1, DLA-DQB1 and DLA-DQA1. Veterinary Immunology and Immunopathology. Vol 156. Issues 3-4. p 205-210

\section{$\underline{\text { INDICE }}$}

Sección Página

Agradecimientos

Resumen

Abstract

Glosario

Abreviaturas

Introducción

1. Enfermedades de origen genético en perros

1.1. Tipo y origen de enfermedades genéticas en perros

1.2. Perros como modelo de enfermedades humanas

1.2.1. Origen del perro domestico

1.2.2. El perro como modelo de enfermedad autoinmune

1.3. Enfermedades inmunomediadas

1.3.1. Mecanismos inmunopatológicos

1.4. Genes involucrados en la respuesta inmune

1.4.1. Respuesta inmune

1.4.2. Complejo Principal de Histocompatibilidad (MHC)

1.5. Mapeo de Genes Asociados a Características Fenotípicas 
1.5.2. Diseños experimentales utilizados para mapeo de genes asociados a caracteres fenotípicos.

1.6. Queratitis superficial crónica en ovejero alemán

1.6.1. Incidencia y prevalencia de la enfermedad en la región y en el mundo.

1.6.2. Estado del arte sobre la herencia de la QSC

Hipótesis

Objetivo General y específicos

2.Materiales y Métodos

2.1. Material animal

2.1.1. Datos fenotípicos

2.1.2. Población estudiada

2.2. Obtención de la muestra y extracción de ADN

2.3. Genotipificación

2.3.1. Microsatélites

2.3.2. Secuenciación

2.3.3. Genes de clase II del Complejo Principal de Histocompatibilidad canino (DLA)

2.3.3.a. Regiones reguladoras de los genes de clase II DLA-DRB1,-DQA1 yDQB

2.3.2.b. Regiones presentadoras de antígenos (exón 2) de los genes de clase II DLA-DRB1, -DQA1 y -DQB1.

2.4. Análisis Bioinformáticos

2.5. Análisis poblacional

2.6. Análisis de asociación

3. Resultados 
3.2. Análisis poblacional $\quad 62$

3.2.1. Microsatélites ligados al DLA

3.2.2. Región Reguladora Proximal de las Genes DLA-DRB1, DLA-DQA1 66 y DLA-DQB1

3.2.3. Región Presentadora de Antígenos (exón 2) de las Genes DLA- 75 DRB1, DLA-DQA1 y DLA-DQB1

3.2.4. Análisis de los haplotipos de la región presentadora de antígenos 82

3.3. Análisis de asociación $\quad 82$

3.3.1. Microsatélites

3.3.2. Región Promotora Proximal de los genes DLA-DRB1, DLA-DQA1 y DLA-DQB1

3.3.3. Segundo exón de los genes DLA-DRB1, DLA-DQA1 y DLA-DQB1

4. Discusión

94

$\begin{array}{ll}\text { 5. Conclusiones } & 103\end{array}$

$\begin{array}{ll}\text { 6. Bibliografía } & 106\end{array}$

$\begin{array}{ll}\text { 7. Anexos } & 118\end{array}$ 


\section{$\underline{\text { Índice de tablas }}$}

Tabla 1.1. Número de Enfermedades genéticas en caninos basado en las categorías detalladas en la base de datos de OMIA

Tabla 1.2. Grupos raciales de perros según la clasificación propuesta por la Federación

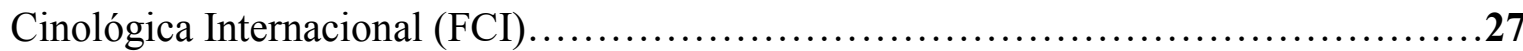

Tabla 1. 3. Comparación de los principales mecanismos inmunopatológicos.............32

Tabla 1.4. Organización molecular del Complejo Mayor de Histocompatibilidad canino.

Tabla 2.1. Características de los microsatélites FH2054, FH2975 y FH2202 utilizados en el presente estudio. 53

Tabla 2.2. Primers utilizado para amplificar las regiones promotoras de los genes de DLADRB1, -DQA1 y-DQB1.

Tabla 2.3. Primers utilizados en la secuenciación del exón 2 de los genes DLA- DRB1, DLA-DQA1 y DLA-DQB1 .58

Tabla 3.1. Frecuencias alélicas del microsatélite FH2054 (tetranucleótido) estimadas en los grupos caso y control.

Tabla 3.2. Valores estimados de heterocigosidad esperada $\left(h_{e}\right)$ y observada $\left(h_{o}\right)$ para el microsatélite FH2054 detectados en los grupos caso y control y la población total.....63 Tabla 3.3. Frecuencias alélicas del microsatélite FH2975 (tetranucleótido) estimadas en los grupos caso y control 64

Tabla 3.4. Valores estimados de heterocigosidad esperada $\left(h_{e}\right)$ y observada $\left(h_{o}\right)$ para el microsatélite FH2975 detectados en los grupos caso y control y la población total.....64

Tabla 3.5. Frecuencias alélicas del microsatélite FH2202 (tetranucleótido) estimadas en los grupos caso y control. 
Tabla 3.6. Valores estimados de heterocigosidad esperada $\left(h_{e}\right)$ y observada $\left(h_{o}\right)$ para el microsatélite FH2202 detectados en los grupos caso y control y la población total..........66 Tabla 3.7. Características de los polimorfismos detectados en la región promotora/exon 1 de los genes de clase II DLA-DRB1, DLA-DQA1 y DLA-DQB1 .67 Tabla 3.8. Frecuencias alélicas, heterocigosidad obsevada $\left(h_{o}\right)$ y esperada $\left(h_{e}\right)$, equilibrio de Hardy-Weinberg (HWE) calculada para cada polimorfismo detectado en los promotores de los genes DLA-DRB1, DLA-DQA1 y DLA-DQB1 en el total de la muestra............71 Tabla 3.9. Heterocigosidad obsevada $\left(h_{o}\right)$ y esperada $\left(h_{e}\right)$, equilibrio de Hardy-Weinberg (HWE) calculada para cada polimorfismo detectado en los promotores de los genes DLADRB1, DLA-DQA1 y DLA-DQB1en los grupos caso y control........................72

Tabla 3.10. Frecuencias haplotípicas de las regiones reguladoras proximales de los genes DLA-DRB1 y DLA-DQB1 en los grupos caso y control...........................75

Tabla 3.11. Código de ambigüedad nucleotídica (IUPAC, International Union of Pure and

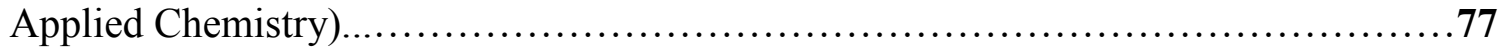

Tabla 3.12. Frecuencias alélicas del exón 2 del gen DLA-DRB1 estimadas en los grupos caso, control y en la población total.... .79

Tabla 3.13. Valores estimados de heterocigosidad esperada $\left(h_{e}\right)$ y observada $\left(h_{o}\right)$ para el exón 2 del gen DLA-DRB1 detectados en los grupos caso y control y la población

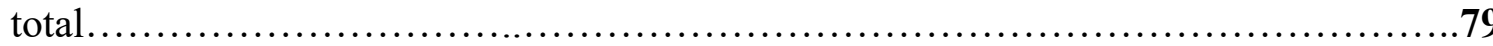

Tabla 3.14. Frecuencias alélicas del exón 2 del gen DLA-DQA1 estimadas en los grupos caso, control y en la población total. .80

Tabla 3.15. Valores estimados de heterocigosidad esperada $\left(h_{e}\right)$ y observada $\left(h_{0}\right)$ para el exón 2 del gen DLA-DQA1 detectados en los grupos caso y control y la población total 
Tabla 3.16. Frecuencias alélicas del exón 2 del gen DLA-DQB1 estimadas en los grupos caso, control y en la población total.

Tabla 3.17. Valores estimados de heterocigosidad esperada $\left(h_{e}\right)$ y observada $\left(h_{0}\right)$ para el exón 2 del gen DLA-DQB 1 detectados en los grupos caso y control y la población total

Tabla 3.18. Haplotipos DRB1/DQA1/DQB1. Frecuencias haplotípicas en el grupo caso, control y población total. .82

Tabla 3.19. Análisis de asociación entre el desarrollo de QSC y los alelos de los microsatélites FH2054, FH2975 y FH2202. .83

Tabla 3.20. Análisis de asociación entre el desarrollo de QSC y la heterocigocidad observada $\left(\mathrm{h}_{\mathrm{o}}\right)$ para los alelos de los microsatélites FH2054, FH2975 y FH 2202 .....84

Tabla 3.21. Frecuencias alélicas estimadas en los grupos caso y control para los promotores de los genes DLA-DRB1, DLA-DQA1 and DLA-DQB1. La frecuencia de cada alelo dentro de cada grupo se comparó utilizando el Test exacto de Fisher y Odds ratio (OR) .85

Tabla 3.22. Frecuencia haplotípica estimada en el grupo caso y control para los promotores de los genes DLA-DRB1 y DLA-DQB1. La frecuencia de cada haplotipo dentro de cada grupo fue comparada usando el test exacto de Fisher y Odds ratio (OR). .85

Tabla 3.23. Análisis del equilibrio de Hardy-Weinberg (HWE) para cada polimorfismo de los promotores de los genes DLA-DRB1, DLA-DQA1 y DLA-DQB1 dentro de los grupos caso y control utilizando el índice $\mathrm{F}_{\mathrm{IS}}$.Las proporciones de homocigotas/heterocigotas entre ambos grupos fueron comparadas mediante el test exacto de Fisher y Odds ratio (OR)...87 Tabla 3.24. Análisis de asociación entre el desarrollo de QSC y los alelos de los exones 2 de los genes DLA-DRB1, -DQA1 y DQB1 
Tabla 3.25. Análisis de asociación entre el desarrollo de QSC y la heterocigocidad observada $\left(h_{0}\right)$ para los alelos de los exones 2 del gen DLA-DRB1, -DQA1, -DQB1......89

Tabla 3.26. Desequilibrio de ligamiento medido en $\mathrm{D}^{\prime}$ entre todos los loci analizados

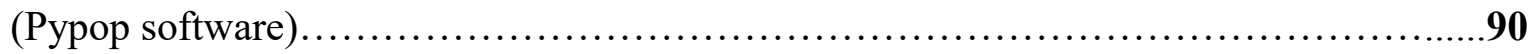

Tabla 3.27. Análisis de asociación entre el desarrollo de QSC y los haplotipos conformados por las regiones presentadoras de antígenos de los genes de clase II DLA-

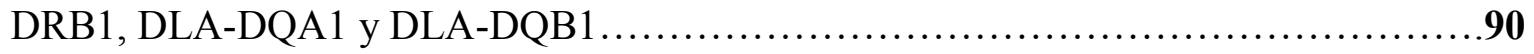

Tabla 3.28. Frecuencias haplotípicas de las regiónes promotoras y presentadoras de antígenos del gen DLA-DQB1 (URR-DQB/exón 2 DQB1) y análisis de asociación

\section{$\underline{\text { Índice de figuras }}$}

Figura 1.1. Representación esquemática del fenómeno de cuello de botella y efecto fundador. 22

Figura 1.2. Árbol filogenético basado en datos de secuenciación masiva. 25

Figura 1.3. Centros de domesticación e historia de la migración y evolución del perro doméstico. .25

Figura 1.4. Factores asociados e interrelacionados al desarrollo de la autoinmunidad. 28

Figura 1.5. Relación entre la inmunidad innata y adaptativa en las tres líneas de defensa del

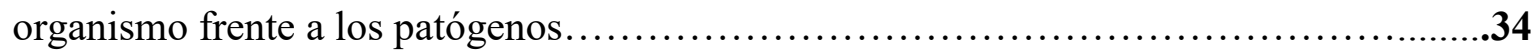

Figura 1.6. Estructura de las moléculas de clase I y II...................................36

Figura 1.7. . Esquema del procesamiento y presentación de antígenos.....................37

Figura1.8. Función de las moléculas de clase II en la presentación de antígenos. .38 
Figura 1.9. Estructura del Complejo Mayor de Histocompatibilidad de mamíferos......40

Figura 1.10 Región donde se ubican los genes DLA de clase II en el Cromosoma 12 canino utilizados en este estudio.

Figura 2.1. Perros de la raza Ovejero Alemán...................................5

Figura 2.2. Signos característicos a la inspección oftalmológica .50

Figura 2.3. Descripción esquemática de la metodología utilizada para la genotipificación de las muestras. .52

Figura 2.4. Localización en la región del DLA de clase II de los microsatélites utilizados en este estudio .54

Figura 2.5. Cromatograma de un fragmento de ADN. .56

Figura 3.1. Alineamiento de la secuencias de las variantes alélicas de las regiones reguladoras proximales de los genes DLA de clase II. 68

Figura 3.2. Haplotipos y desequilibrio de ligamiento (LD) en las regiones reguladoras proximales de los genes DLA-DRB1, DLA-DQA1 y DLA-DQB1 .74 Figura 3.3. Flujo de trabajo del software diseñado para asignar los genotipos de los exones 2 de los genes de clase II. .78

Figura 3.4. Distribución de los haplotipos detectados en los grupos caso y control. Se marcó con una flecha el haplotipo 3, el cual evidenció diferencias significativas (haplotipo protector) 91

\section{$\underline{\text { Índice de anexos }}$}

ANEXO 1. Planilla de examen ocular. 118 ANEXO 2. Modelo de consentimiento informado presentado a los propietarios de los animales muestreados 
ANEXO 3. Kit de purificación de ADN genómico Wizard® (Promega, Madison, WI,

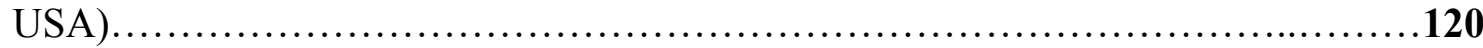

ANEXO 4. Protocolo de extracción orgánica de ADN total de sangre periférica.....121

ANEXO 5.Cuantificación del ADN extraído y productos de PCR purificados.....122

ANEXO 6. Chequeo de productos de PCR en geles de poliacrilamida $6 \%$. 123

ANEXO 7.Purificación de las reacciones de PCR por precipitación con polietilenglicol

(PEG)

.124

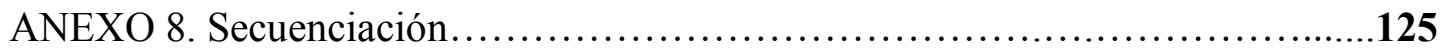

ANEXO 9. Esquema de un proceso de secuenciación............................127

ANEXO 10. Protocolos de amplificación.........................................128

ANEXO 11. a) Geles de poliacrilamida 6\%. Chequeo de productos de PCR

(Microsatélites)

b) Cromatogramas de los microsatélites

ANEXO 12. Alineamiento de las secuencias reportadas para el exón 2 de los genes DLA de clase II. Base de datos IPD-MHC 


\section{Resumen}

La Queratitis Superficial Crónica (QSC) es una enfermedad inflamatoria corneal que puede conducir a la ceguera del animal si no es tratada. La QSC se presenta con mayor frecuencia en el perro Ovejero Alemán (OA). Mientras que la córnea normal tiene una baja expresión de MHC de clase II, en la QSC se produce la sobreexpresión de estas moléculas, asociado con la secreción de interferón gamma por los linfocitos T CD4+ del infiltrado inflamatorio. Numerosas evidencias apoyan la hipótesis de que QSC es una enfermedad inmunomediada. Debido a esto, para investigar los factores genéticos moleculares que pueden estar asociados con el desarrollo de QSC se tipificaron 73 perros (43 animales enfermos y 30 animales control) para los siguiente marcadores genéticos: 3 microsatélites (FH2202, FH2054 y FH2975) ligados a la región de clase II del DLA (Dog Leukocyte Antigen o Antígeno Leucocitario Canino), las regiones reguladores proximales (URR) y las regiones presentadoras de antígenos (exón 2) de los genes DLA de clase II DLA-DRB1, DLADQA1 y DLA-DQB1. Se observó asociación significativa en los tres tipos de marcadores. En cuanto a los microsatélites, los alelos FH2054*172 (valor de p = 0,02) y FH2975*320 (valor de $\mathrm{p}=0,005$ ) se asociaron a un mayor riesgo al desarrollo de QSC. En cuanto a las regiones reguladoras, el haplotipo URR-DQB*TATC se asoció significativamente con la QSC ( $\mathrm{p}=0,006)$, evidenciando una aumento de 3 veces el riesgo de desarrollar esta enfermedad $(\mathrm{OR}=2,87,95 \%, \quad \mathrm{IC}=1,43-81) . \mathrm{El}$ haplotipo de exones 2 DRB1*00101/DQA1*00101/ DQB1*00201 se asoció con un menor riesgo a desarrollar QSC $(p=0,02)(\mathrm{OR}=0,2,95 \%, \mathrm{IC}=0.07-0,81)$. Aunque, el haplotipo conformado por el promotor $y$ el exón 2 de DLA-DQB1/URR-DQB*TATC/*01302 se asoció significativamente con la QSC ( $\mathrm{p}=0,003$ ), aumentando casi 5 veces el riesgo a desarrollar la enfermedad $(\mathrm{OR}=4,56,95 \% \mathrm{IC}=1,74-16,53)$. Este trabajo confirma el rol de $\mathrm{MHC}$ de clase II en el desarrollo de la QSC y proporciona nuevos datos sobre la población local de OA. Esta asociación genética también es compatible con los estudios clínicos, histológicos

y farmacológicos reportados, que indican que la QSC es una enfermedad inmunomediada. Potencialmente estos marcadores podrían ser utilizados para identificar animales susceptibles y para dirigir los cruzamientos en los criaderos.

Palabras claves: Perros, Marcadores genéticos, Enfermedades autoinmunes, Queratitis Superficial Crónica, MHC, Estudio de asociación 


\begin{abstract}
Canine chronic superficial keratitis (CSK) is an inflammatory corneal disease that leads to blindness if not treated. CSK occurs most frequently in the German Shepherd dog (GSDs). While the normal central cornea has little MHC class II expression, aberrant expression occurs in CSK, associated with secretion of gamma interferon by infiltrating CD4 expressing lymphocytes. Several evidences lend support to the hypothesis that CSK is an immune-mediated disease. Accordingly, to investigate the molecular genetic factors that may be associated to CSK development: 3 STRs (short tandem repeats) linked to DLA (Dog Leukocyte Antigen) class II region (FH2202, FH2054 y FH2975, upstream regulatory regions (URR) and ARS (exon 2) of DLA class II DLA-DRB1, DLA-DQA1 and DLADQB1 genes were genotyped in 73 dogs, including 43 CSK animals. Association was observed in all types of markers, allele FH2054*172 (p value $=0.02$ ) and FH2975*320 (p value $=0.005)$ were associated with a higher risk to develop CKS. The URR-DQB*TATC haplotype was significantly associated with CSK $(\mathrm{p}=0.006)$, increasing almost three folds the risk to develop this disease $(\mathrm{OR}=2.87,95 \%, \mathrm{CI}=1.43-81)$. Furthermore, the haplotype DRB1*00101/DQA1*00101/DQB1*00201 was associated with a low risk to develop CSK $(\mathrm{p}=0.02, \mathrm{OR}=0.2,95 \%, \mathrm{CI}=0.07-0.81)$. Although, the haplotype conformed by promoter and exon 2 of DLA-DQB1 URR-DQB*TATC/*01302 was significant associated with CSK $(\mathrm{p}=0.003, \mathrm{OR}=4.56,95 \%, \mathrm{CI}=1.74-16.53)$ increasing five folds the risk to develop the disease. This study confirms the role of MHC class II in the development of CSK and provides new data about the local population of GSD. This genetic association also supports the previous clinical, histological and pharmacological studies of CSK as an immune-mediated disease and could potentially be used to identify susceptibly animals that require monitoring for early pathological changes to reduce blindness and to ameliorate reproductive management.
\end{abstract}

Key words: Dogs, Genetic markers, Autoimmmune diseases, Chronic Superficial Keratitis, MHC, Association study. 


\section{GLOSARIO}

ALELO DE RIESGO: Variante alélica que presenta una frecuencia significativamente mayor en el grupo de animales afectados que en el grupo de animales sanos.

CITOQUINAS: Proteínas que regulan las interacciones de las células del sistema inmune. Su función fundamental en la respuesta inmune, la inflamación y la hematopoyesis de distintos tipos celulares.

ENFERMEDAD AUTOINMUNE: Enfermedad caracterizada por una respuesta inmune patológica (enfermedad inmunomediada) en contra de los tejidos propios. Se clasifican en primarias, cuando no tienen causa subyacente identificada, y secundarias, cuando tienen una causa subyacente (ej. Infecciones, neoplasias).

ENFERMEDAD DE ORIGEN GENÉTICO: Afecciones causada por alteraciones en el genoma. La gran mayoría de ellas son hereditarias.

ENFERMEDAD INMUNOMEDIADA: Enfermedad caracterizada por el daño tisular causado por la activación inapropiada de los efectores del sistema inmune. Esta respuesta inmune patológica puede estar dirigida a agentes infecciosos, a sustancias aparentemente inocuas o a los llamados autoantígenos.

ESTUDIO CASO-CONTROL: Estudio epidemiológico, observacional y analítico, en el cual los individuos se seleccionan en función de que tengan (casos) o no tengan (control) una determinada enfermedad. Una vez seleccionados los individuos en cada grupo, se investiga si estuvieron expuestos o no a una característica de interés y se los compara.

GENOMA: Totalidad de la información genética de un organismo.

GRUPO FUNDADOR: Individuos que dan origen a una población nueva con características propias.

LINFOCITO B: Leucocitos mononucleares (agranulocitos) responsables de la respuesta humoral, transformándose en plasmocitos productores de anticuerpos o inmunoglobulinas (Ig), las cuales se adhieren a un antígeno específico. Interactúan con los linfocitos T con lo que proliferan y cambian el isotipo de inmunoglobulina (IgM, $\operatorname{IgE}, \operatorname{IgG}, \operatorname{IgD}, \operatorname{IgA})$ que secretan, manteniendo la especificidad del antígeno. Pueden actuar como células presentadoras de antígenos. 
LINFOCITOS T: Leucocitos mononucleares (agranulocitos) que detectan antígenos proteicos asociados a moléculas del complejo mayor de histocompatibilidad (MHC). -Linfocitos T colaboradores (en inglés "helper") o linfocitos CD4+. Reconocen antígenos presentados por el MHC de clase II en células dendríticas, linfocitos B, macrófagos y otras células presentadoras de antígenos. Se les denomina colaboradores porque están involucrados en la activación y dirección de otras células del sistema inmune. -Linfocitos T citotóxicos o linfocitos CD8+. Reconocen péptidos presentados por MHC de clase I y tienen capacidad la capacidad de lisis célular.

MICROSATÉLITE: Marcador genético que consiste en secuencias básicas de 2-4 nucleótidos, cuya repetición en tándem origina frecuentemente secuencias de menos de 150 nucleótidos. Son polimorfismos multialélicos en los que la variación está dada por la diferencia en el número de repeticiones.

MONOGÉNICO: Carácter o afección atribuida a la variación de un solo gen.

POLIGÉNICO: Carácter o afección atribuida a la variación de varios genes. QUERATITIS: Inflamación de la córnea (primer medio transparente del ojo) RESPUESTA INMUNE ADAPTATIVA: Reacción del sistema inmune específica, la cual mejora con cada exposición al antígeno, deja memoria y es filogenéticamente más reciente

RESPUESTA INMUNE INNATA: Reacción del sistema inmune inespecífica que se desarrolla cada vez que el organismo se enfrenta al patógeno, no deja memoria y es filogenéticamente más antigua. Está presente desde el nacimiento y actúa en la primera y segunda línea de defensa.

SISTEMA INMUNE: Conjunto de moléculas, células y tejidos especializados en la función de defender al organismo contra la agresión producida por una gran variedad de agentes patógenos y controlar el desarrollo tumoral. 


\section{ABREVIATURAS}

ADN: Ácido desoxirribonucleico.

AKC: American Kennel Club.

CFA: Canine (Canis lupus familiaris) chromosome.

CNK: Células Natural Killer.

CPA: Célula Presentadora de Antígenos.

ddNTPs: didesoxi-dinucleótidos trifosfato.

DLA: Dog Leukocyte Antigen (Antígeno Leucocitario Canino).

dNTPs: dinucleótidos trifosfato.

EDTA: Etilendiaminotetraacético (anticoagulante).

FCI: Federación Cinológica Internacional.

$\mathbf{h}_{\mathrm{e}}$ : Heterocigocidad esperada

$\mathbf{h}_{\mathbf{0}}$ : Heterocigocidad observada.

HWE: Hardy-Weinberg Equilibrium (Equilibrio de Hardy-Weinberg).

IC: Intervalo de confianza.

INDEL: Inserción-Deleción (Tipo de polimorfismo genético).

kb: kilobases (1000 pb).

LD: Linkage Desequilibrium (Desequilibrio de ligamiento).

MHC: Major Histocompatiblity Complex (Complejo Mayor de Histocompatibilidad).

mM: milimolar.

ng: nanogramo.

pb: pares de bases (distancia genética).

PCR: Polymerase Chain Reaction (Reacción en cadena de la polimerasa).

QSC: Queratitis Superficial Crónica (Pannus).

SBT: Tipificación basada en secuenciación.

SNP: Single Nucleotide Polymorphism (Polimorfismo de nucleótido simple)

STR: Short tandem repeat (microsatélites)

TNF: Tumor Necrosis Factor (Factor de necrosis tumoral).

$\boldsymbol{\mu M}$ : micromolar. 
1-INTRODUCCIÓN 


\section{1-INTRODUCCIÓN}

\section{Enfermedades de origen genético en perros}

\subsection{Tipo y origen de enfermedades genéticas en perros}

Se define como enfermedades de origen genético a las afecciones causadas por alteraciones en el genoma. La gran mayoría de ellas son hereditarias y pueden ser descriptas como monogénicas (atribuidas a la variación en un solo gen), poligénicas (atribuidas a la variación en varios genes) o multifactoriales (con base genética y ambiental).

La especie Canis lupus familiaris (perro doméstico), debido a la selección y a la formación de las razas, muestra gran variabilidad fenotípica entre razas. Por ejemplo en la característica del tamaño la diferencia entre la raza más pequeña (Chihuahua) y la más grande (Gran Danes) es de 40 veces (Wayne y Ostrander, 2007). Debido al origen de un reducido grupo fundador y a las restricciones generadas por el modo de cría de las diferentes razas, se observa una estructura poblacional particular en donde cada raza se encuentra aislada genéticamente (Parker y col., 2004). A su vez, cada raza presenta una variabilidad genética reducida y un tamaño efectivo de la población pequeño debido, básicamente, a dos efectos de cuello de botella: el primero ocurrido durante la domesticación del perro y el segundo en la creación de las diferentes razas, por la selección a favor de ciertas características fenotípicas específicas (estándar racial) y por el uso repetido de los mismos reproductores ("popular sire") (Mellanby y col., 2013). A este fenómeno se le llama efecto fundador (Figura 1.1). Por lo tanto, se pierde variabilidad genética cuando se establece una nueva población a partir de un número pequeño de individuos perteneciente a una población más grande, obteniéndose como resultado individuos genética y fenotípicamente diferentes a la población original (menor heterocigosidad) (Hedrick, 2005). 
Figura 1.1. Representación esquemática del fenómeno de cuello de botella (a) y efecto fundador (b).

a)

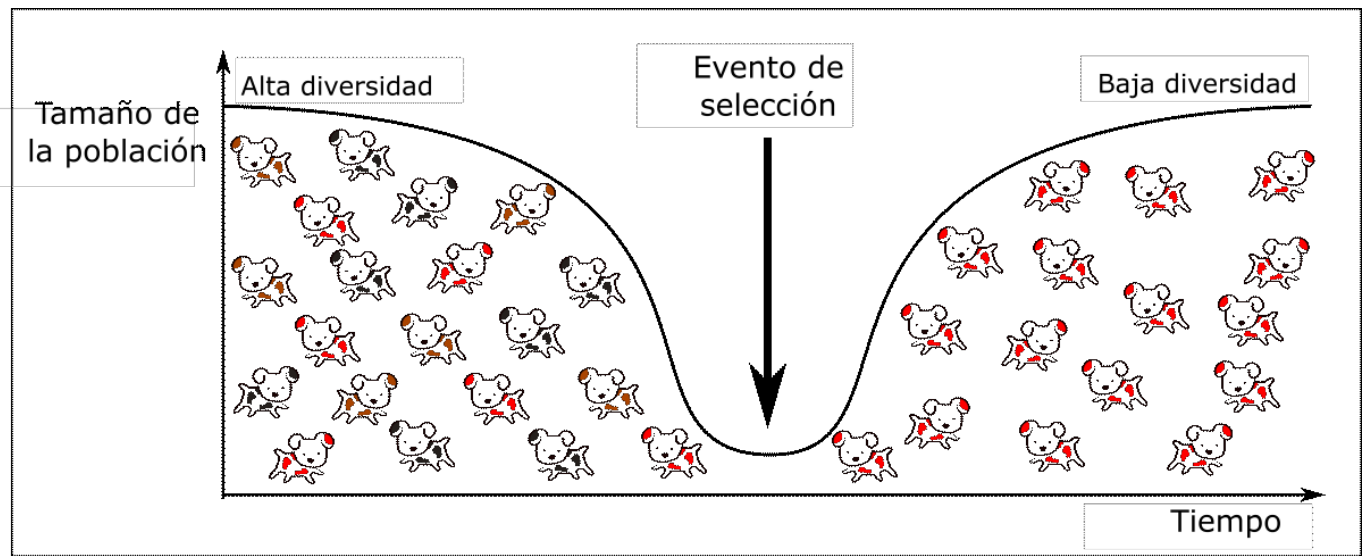

b)

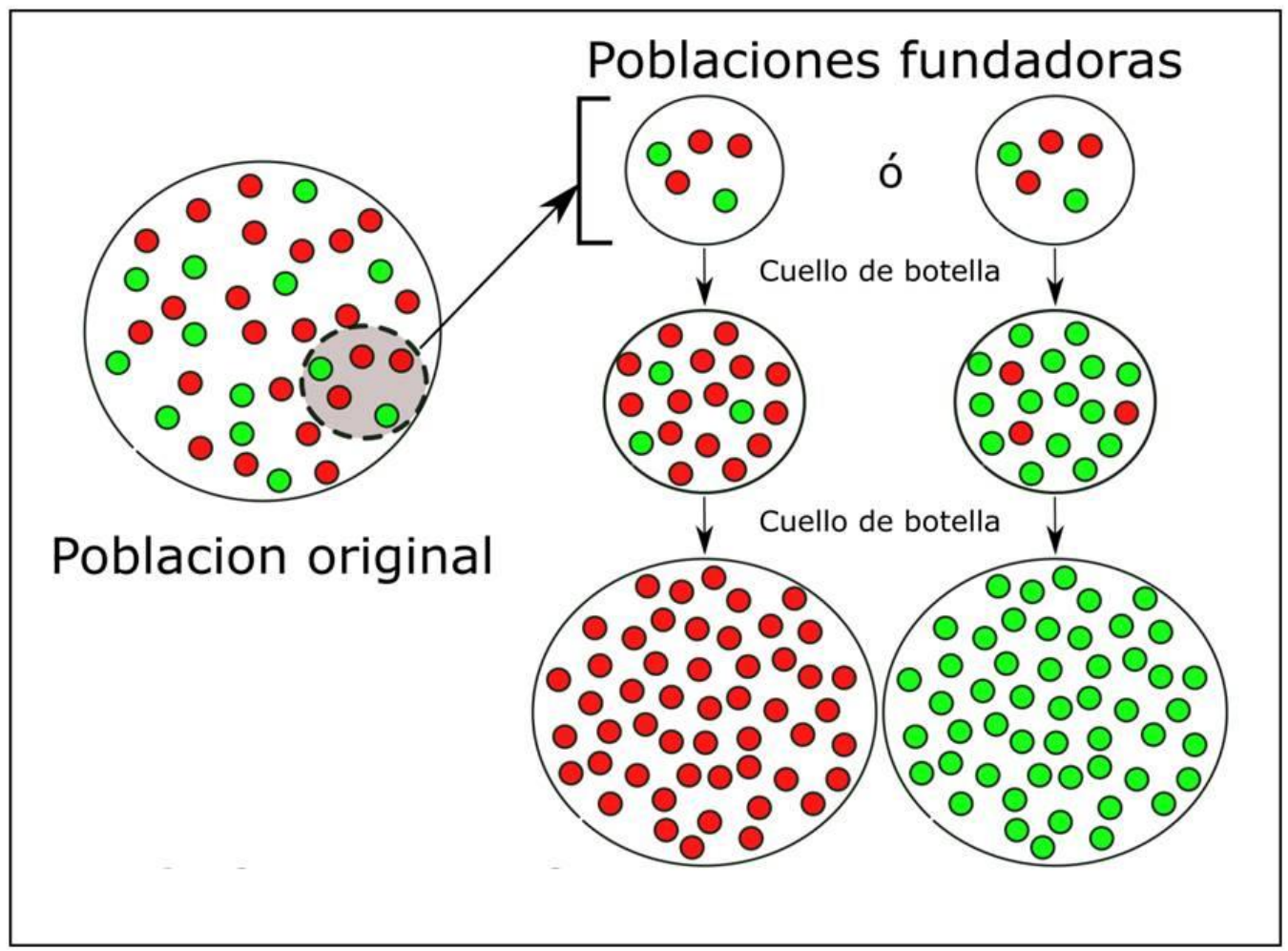


La sobrerrepresentación del genoma del pequeño grupo de reproductores fundadores genera un aumento de la frecuencia de alelos recesivos deletéreos e incrementa la probabilidad de alelos indeseables idénticos por descendencia en la próxima generación (Calboli y col., 2008).

Se han clasificado a las enfermedades genéticas en relacionadas y no relacionadas directamente con el estándar racial, llegando estas últimas a un 75\% del total siendo atribuidas a un pequeño tamaño efectivo de la población, uso repetido de reproductores populares y consanguinidad (Asher y col., 2009; Summers y col., 2010). Por lo tanto, la formación de las razas caninas ha sido asociada con el incremento de la prevalencia de un gran número de enfermedades genéticas (Björnerfeldt y col., 2008), el ejemplo clásico es el síndrome braquiocefálico consecuencia de la selección fenotípica en la raza Boxer y Bulldog (Packer y col., 2015). La alta susceptibilidad a enfermedades específicas en determinadas razas, así como su incidencia mucho menor o ausencia completa en otras razas, sugiere fuertemente la presencia de alelos de riesgo, es decir, variantes alélicas que presentan una frecuencia significativamente mayor en el grupo de animales afectados que en el grupo de animales sanos. Los alelos de riesgo, si tomamos la población general, poseen una baja frecuencia, ya que si éstos fuesen variantes comunes todas las razas presentarían incidencias similares para cada enfermedad y esto no ocurre. De hecho, el $46 \%$ de las enfermedades genéticas reportadas en los perros se cree que se produce predominantemente o exclusivamente en una o unas pocas razas relacionadas en su origen (Patterson, 2000).

En la actualidad, se han reportado un total de 683 enfermedades de origen genético en caninos, de las cuales solo en 208 se conoce la mutación causal y en muchas aún no está claro o es controversial su modo de herencia (Tabla 1.1.). Es de destacar que por su similitud con enfermedades humanas, 365 de ellas son potenciales modelos para estudios de investigación (OMIA, 2016). Entre las enfermedades genéticas caninas es posible encontrar diferentes modos de herencia mendeliana o poligénica, así por ejemplo:

Autosómicas recesivas: CEA o Anomalía del ojo de Collie (Pedersen y col., 2004). Autosómicas dominantes: PRA o Atrofia progresiva de retina en el Mastiff inglés (Marsili y col., 2015). 
Ligados al X o ligadas al sexo: GRMD o Distrofia muscular del Golden Retriever (Brinkmeyer-Langford y Komegay, 2013).

Poligénicas y multifactoriales: CHD o Displasia de cadera en Ovejero Alemán y Labrador Retriever (Fels y col., 2014).

Tabla 1.1. Número de Enfermedades genéticas en caninos basado en las categorías detalladas en la base de datos de OMIA (septiembre, 2016).

\begin{tabular}{lc}
\hline \multicolumn{1}{c}{ Categoría } & Cantidad \\
\hline Total de características/enfermedades & 683 \\
Condición de herencia mendeliana & 283 \\
Condición con mutación causal reconocida & 208 \\
Potenciales modelos de enfermedades humanas & 385 \\
\hline
\end{tabular}

\subsection{Perros como modelo de enfermedades humanas}

\subsubsection{Origen del perro domestico}

El origen del perro doméstico es aún materia de discusión en la comunidad científica, tanto el lugar geográfico como el momento son controversiales. Hay estudios que sugieren que la domesticación comenzó entre 10 mil y 33 mil años atrás (Davis y Valla, 1978; Pang y col., 2009; Skoglund y col., 2011; Larson y Bradley, 2014; Wang y col., 2015). Un estudio reciente (Wang y col., 2015), utilizando secuencias del genoma completo de diferentes cánidos (Figura 1.2), reveló que existe una mayor diversidad genética en las poblaciones de Asia del Este comparada con las otras, lo que sugiere que allí se localizó el grupo que originó el perro doméstico 33 mil años atrás. Luego, hace 15 mil años, un subgrupo migró a Oriente Medio, África y Europa. Uno de los linajes de Asia también emigraron hacia el este, creando una serie de poblaciones mezcladas con los linajes asiáticos endémicos (Figura 1.3). 
Figura 1.2. Árbol filogenético basado en datos de secuenciación masiva (Tomado de Wang y col., 2015)

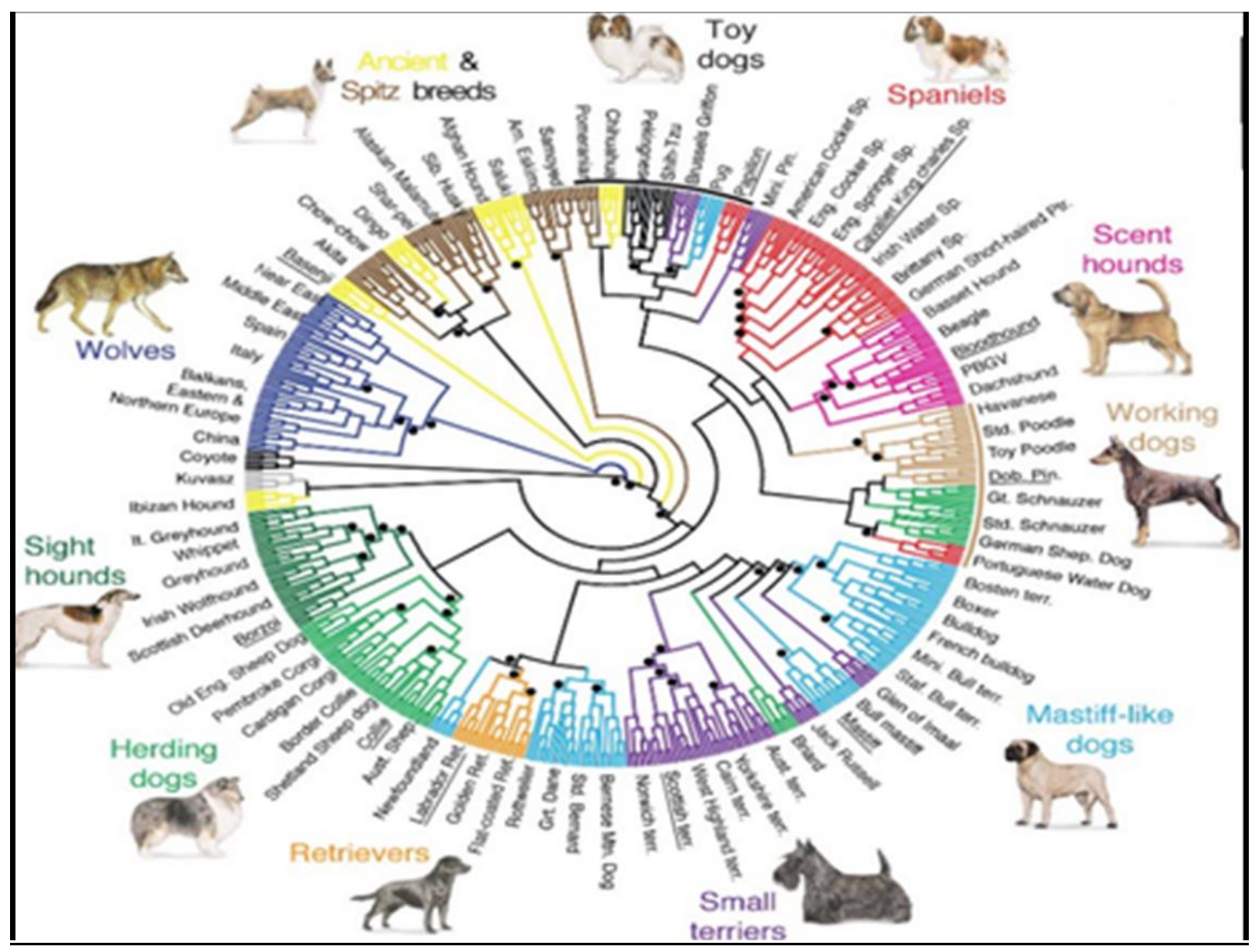

Figura 1.3. Centros de domesticación e historia de la migración y evolución del perro doméstico (tomado de Wang y col., 2015).

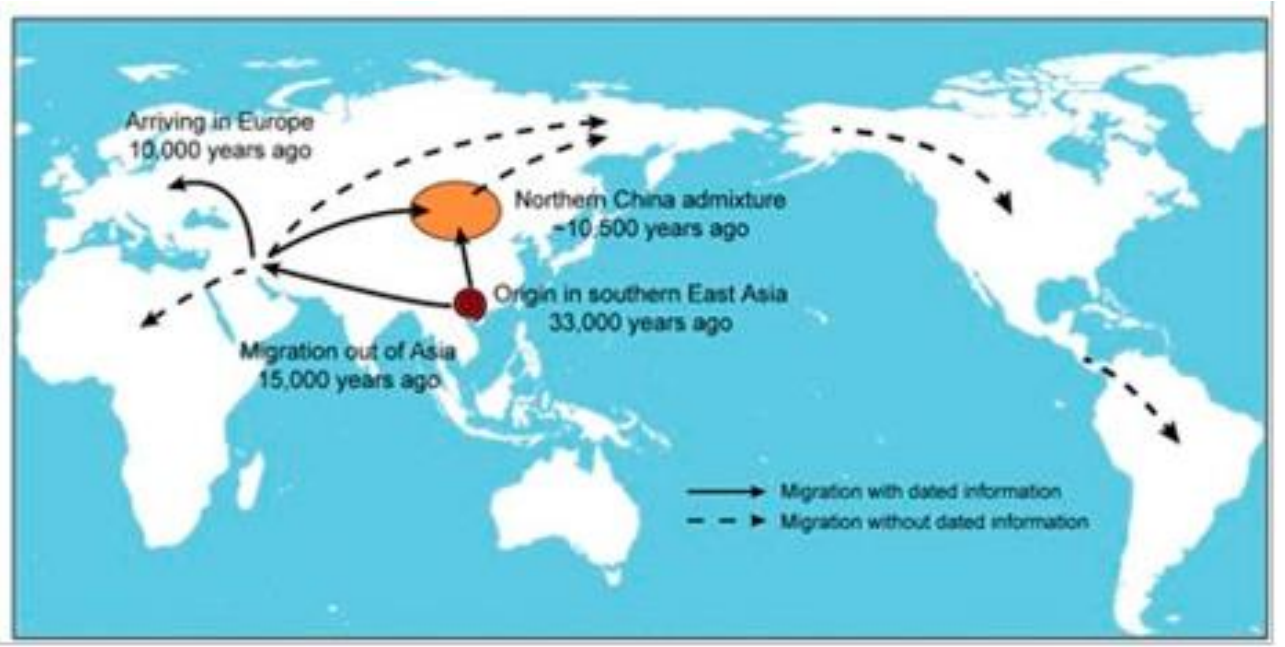


La población de perros puros está compuesta por más de 350 (FCI, 2016) islas genéticas llamadas razas (Tabla 1.2.), todos derivados de un ancestro común, el lobo. A pesar de haber sido la primer especie domesticada, la mayoría de las razas son relativamente nuevas, producto de la intensa selección artificial impuesta por el ser humano en los últimos 300 años (Wilcox y Walkowicz 1995; Wayne y Ostrander, 1999; Rimbault y Ostrander, 2012) y, como ya se dijo en la sección anterior, derivan de un pequeño número de individuos fundadores que poseían las características físicas y de comportamiento deseadas para un determinado fin. Por esta razón, muchas de las razas actuales tienen una variabilidad genética limitada con predisposición a ciertas enfermedades derivada de uno o unos pocos antecesores. Esta gran cantidad de razas caninas fue dividida por la Federación Cinológica Internacional en 10 grupos con características fenotípicas y usos similares (Tabla 1.2.). Dentro de cada grupo se pueden encontrar numerosos ejemplos de enfermedades compartidas por las razas que lo componen, por ejemplo la osteocondrosis en las razas gigantes pertenecientes al grupo 2 (Nemanic y col., 2016) 
Tabla 1.2. Grupos raciales de perros según la clasificación propuesta por la Federación Cinológica Internacional (FCI).
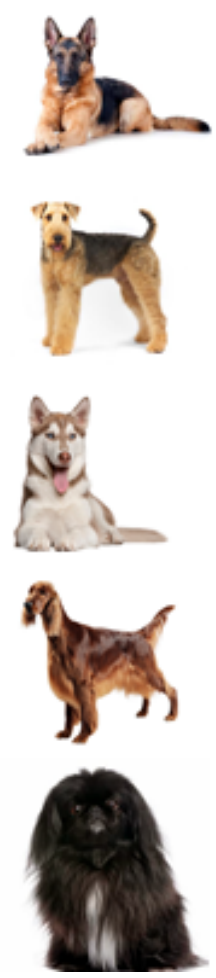

GRUPO 1

Pastores y Boyeros (excepto Boyeros Suizos)

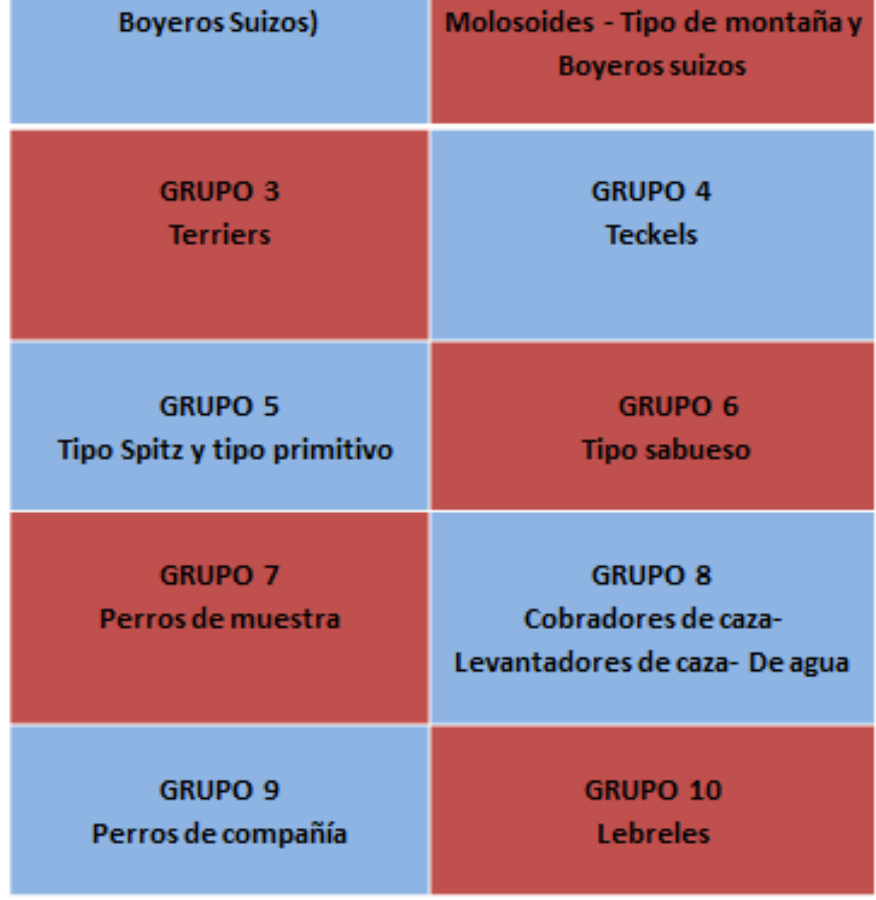

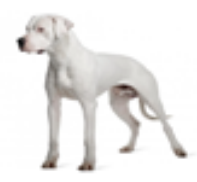
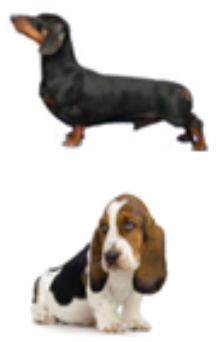

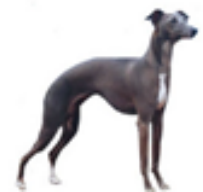




\subsubsection{El perro como modelo de enfermedad autoinmune}

Las características únicas de la estructura genético poblacional de las razas caninas, hacen de esta especie un excelente modelo para el estudio de enfermedades de origen genético, debido principalmente al elevado desequilibrio de ligamiento dentro de cada raza y al elevado nivel de estructuración poblacional. Es por esta razón que empleando un menor número de marcadores genéticos y un menor tamaño de muestra con respecto a estudios humanos, ha sido posible mapear loci asociados a diferentes enfermedades (Parker y col., 2010).

Se define como autoinmunidad a una respuesta inmunológica anómala frente a uno o varios antígenos propios. Se caracteriza por la pérdida de tolerancia inmune. Si esta respuesta persiste, provocará una lesión tisular que dará lugar a la enfermedad autoinmune, caracterizada por la activación de los linfocitos $\mathrm{B}$, linfocitos $\mathrm{T}$, o ambos. Para el desarrollo de este tipo de enfermedades hay varios factores asociados: inmunológicos, hormonales, genéticos y ambientales (Figura 1.4). Cualquier mamífero puede ser afectado por una enfermedad autoinmune, ya sea órgano-específica (la gran mayoría) o multisistémica (Lopez García, 2013).

Figura 1.4. Factores asociados e interrelacionados al desarrollo de la autoinmunidad.

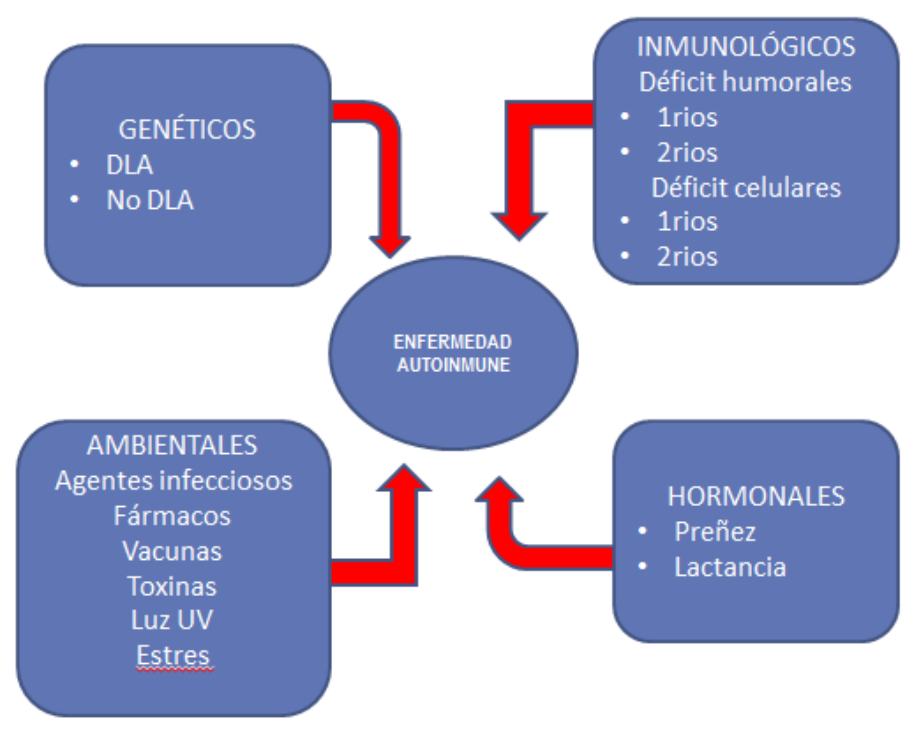


En humanos, son las afecciones de mayor importancia médica y económica, entre ellas se encuentran la Diabetes mellitus, la Artritis Reumatoidea, la Tiroiditis de Hashimoto y el Lupus eritematoso sistémico. En medicina veterinaria, el perro es la especie doméstica que tiene mayor prevalencia de estas enfermedades y son muy similares a sus equivalentes humanas en cuanto a la base inmunológica, fisiopatología y presentación clínica. (Day y Shultz, 2014).

En humanos, la mayoría de las enfermedades genéticas autoinmunes muestran modos de herencia complejos lo que dificulta el análisis genético. Los modelos en roedores son los más manejables genéticamente pero los resultados tienen una importancia limitada debido a las profundas diferencias fisiológicas existentes. En comparación, la patogenia y la respuesta clínica de los perros son similares a las enfermedades humanas. Las razas caninas ofrecen todas las ventajas de las poblaciones humanas aisladas geográficamente, pero con un mayor grado de aislamiento, cuellos de botella más estrechos, y mucho mejores registros genealógicos (Ostrander, 2000). Otra de las ventajas que ofrece el perro como modelo para el análisis de enfermedades humanas es que de las casi 700 enfermedades de origen genético caninas reportadas más de la mitad son similares a los trastornos humanos (OMIA, 2016).

Diferentes estrategias han sido utilizadas para mapear los genes y mutaciones involucradas en el desarrollo de una enfermedad genética. Entre ellas se encuentran los estudios de mapeo por asociación genómica que se basan en la asociación entre alelos de un gen y una enfermedad, y estos con marcadores vecinos. Por lo tanto, dependen del nivel de desequilibrio de ligamiento (LD) debido a que la cantidad de marcadores tipificados es limitada. Estas asociaciones surgen cuando la mayoría de los alelos asociados a enfermedad en una población comparten el mismo origen ancestral. En una población, cuanto mayor es el LD menor cantidad de marcadores deben ser tipificados. Por lo tanto, la estructura de las razas caninas reduce los problemas del estudio de las enfermedades hereditarias asociados a la heterogeneidad, complejidad genética y registro genealógico. Por el contrario, un mayor LD tiene como consecuencia negativa que la región cromosómica asociada es de mayor tamaño, y por lo tanto, incluye un mayor número de posibles genes candidatos causales de la enfermedad. Sin embargo, la disponibilidad en la actualidad de genomas con buenos niveles de anotación facilita la selección de los posibles genes a ser secuenciados con el fin 
de detectar la mutación causal. Esto hace que el mapeo por LD sea una buena estrategia para detectar a los genes responsables de enfermedad (Sutter y col., 2004).

\subsection{Enfermedades inmunomediadas}

Las enfermedades inmunomediadas se caracterizan por el daño tisular causado por la activación inapropiada de los efectores del sistema inmune. Esta respuesta inmune patológica puede estar dirigida a agentes infecciosos contribuyendo a la presentación clínica de la enfermedad (ej. Babesiosis canina), a sustancias aparentemente inocuas (ej. Alergia alimentaria o dermatitis atópica) o a los llamados autoantígenos, es decir contra el propio tejido del que genera la respuesta (enfermedad autoinmune primaria). Se considera enfermedad autoinmune primaria a la que no tiene una causa subyacente bien definida y se cree que está causada por un desbalance o una disfunción del sistema inmune. El término enfermedad autoinmune secundaria se utiliza para describir desordenes inmunomediados en los que la causa subyacente puede ser identificada, por ejemplo: infecciones, toxinas, vacunas o neoplasias (Nelson y Couto, 2014).

\subsubsection{Mecanismos inmunopatológicos}

Las lesiones inmunopatológicas se dan por cuatro mecanismos básicos (Tabla 1.3.). Estos forman parte, tanto de la respuesta inmune normal como de la patogenia de las enfermedades inmunomediadas. Los mecanismos son:

Mecanismos de tipo I: Mediada por Ig E y la degranulación de mastocitos. La exposición del antígeno activa las células T CD4+ (helper) y la diferenciación de los linfocitos B a célula plasmática (productora de Ig). Los mastocitos tienen receptores para Ig E. En una segunda exposición al antígeno, los anticuerpos específicos activan la degranulación de los mastocitos. Ejemplo: Reacción anafiláctica aguda. 
Mecanismos de tipo II: Mediada por anticuerpos. Se producen IgG e IgM que se unen a la célula diana, lo cual desencadena fagocitosis o lisis de las mismas. Ejemplo, Anemia hemolítica autoinmune.

Mecanismos de tipo III: Mediada por inmunocomplejos. Se depositan complejos Antígeno-Anticuerpo en los tejidos, se activa el complemento y se atrae a los leucocitos a la zona. Ejemplo, Lupus eritematoso sistémico.

Mecanismos de tipo IV: Mediada por células. Los linfocitos T activados, se liberan citoquinas, se produce inflamación y activación de macrófagos. Ejemplo, Diabetes tipo I. 
Tabla 1.3. Comparación de los principales mecanismos inmunopatológicos (Modificado de Nelson y Couto, 2014)

\begin{tabular}{|c|c|c|c|c|}
\hline $\begin{array}{l}\text { TIPO DE } \\
\text { MECANISMO }\end{array}$ & Inmunoreactante & Antígeno & $\begin{array}{l}\text { MECANISMO DEL } \\
\text { EFECTOR }\end{array}$ & EJEMPLOS \\
\hline $\begin{array}{l}\text { Tipo I } \\
\text { (Inmediato) }\end{array}$ & $\lg \mathrm{E}$ & $\begin{array}{l}\text { Antígeno } \\
\text { soluble }\end{array}$ & Activación de mastocitos & $\begin{array}{l}\text { Reacción } \\
\text { anafiláctica } \\
\text { aguda, Rinitis } \\
\text { alérgica, Asma. }\end{array}$ \\
\hline $\begin{array}{l}\text { Tipo II } \\
\text { (Citotóxico) }\end{array}$ & $\lg G$ & $\begin{array}{l}\text { Antígeno } \\
\text { asociado a } \\
\text { células o matriz } \\
\text { extracelular }\end{array}$ & $\begin{array}{l}\text { Activación de células FeR+ } \\
\text { (CNK y fagocitos) }\end{array}$ & $\begin{array}{l}\text { Anemia } \\
\text { hemolítica } \\
\text { inmunomediada } \\
\text {, Pénfigo } \\
\text { foliáceo. }\end{array}$ \\
\hline $\begin{array}{l}\text { Tipo III } \\
\text { (Por } \\
\text { inmunocompl } \\
\text { ejos) }\end{array}$ & $\lg G$ & $\begin{array}{l}\text { Antígeno } \\
\text { Soluble } \\
\text { (inmunocomplejas) }\end{array}$ & $\begin{array}{l}\text { Activación de células FeRt } \\
\text { (CNK y fagocitos) y del } \\
\text { complemento }\end{array}$ & $\begin{array}{l}\text { Glomérulonefrit } \\
\text { is, LES, }\end{array}$ \\
\hline $\begin{array}{l}\text { Tipo IV } \\
\text { (Retardado) }\end{array}$ & CélulasTh1/Th2 & $\begin{array}{l}\text { Antígeno } \\
\text { Soluble }\end{array}$ & $\begin{array}{l}\text { Activación de } \\
\text { macrófagos, eosinófilos y } \\
\text { Citotoxicidad }\end{array}$ & $\begin{array}{l}\text { Tiroiditis } \\
\text { linfocitica }\end{array}$ \\
\hline
\end{tabular}

Como se mencionó anteriormente las enfermedades autoinmunes se definen como el daño tisular, localizado o sistémico, provocado por una respuesta autoinmune frente a uno o varios antígenos propios. Estas enfermedades se pueden dar por tres tipos de mecanismos inmunopatológicos de tipo II, III y IV (Day y Shultz, 2014, Tabla 1.3).

Así como hay mayor prevalencia de ciertas enfermedades autoinmunes en ciertas etnias o familias humanas o líneas de ratones, en las razas caninas sucede lo mismo (Day y Shultz, 2014). La elevada incidencia de enfermedades específicas en determinadas razas, 
indicarían que unos pocos factores de riesgo podrían haberse acumulado dentro de cada raza como consecuencia de la deriva génica y selección. Estas particularidades hacen de los perros un muy buen modelo para la identificación de rutas involucradas en enfermedades humanas complejas (Wilbe y col.,2010).

\subsection{Genes involucrados en la respuesta inmune}

\subsubsection{Respuesta inmune}

Se ha definido tradicionalmente al sistema inmune como un conjunto de moléculas, células y tejidos especializados en la función de defensa del organismo contra la agresión producida por una gran variedad de agentes patógenos y control del desarrollo tumoral. El sistema inmune puede dividirse en dos partes principales para facilitar su estudio: innato y adaptativo. La respuesta inmune innata se desarrolla cada vez que el organismo se enfrenta al patógeno, no deja memoria y es filogenéticamente más antigua. La respuesta inmune adaptativa mejora con cada exposición al antígeno, deja memoria y es filogenéticamente más reciente (Rugeles López, 2009). La acción integrada de ambas respuestas hace que el organismo, aun viviendo en un ambiente poblado de agentes patógenos, solo en ocasiones tenga una enfermedad infecciosa (Figura 1.5).

Dentro de los componentes de la respuesta innata se encuentran:

- Las barreras físicas: piel y mucosas.

- Componentes celulares: Neutrófilos, eosinófilos, macrófagos, células NK, mastocitos, células dendríticas, células endoteliales.

- Componentes humorales: Sistema del complemento, proteínas de fase aguda, interferón $\alpha$ y $\beta$.

Dentro de los componentes de la respuesta adaptativa se encuentran:

- Componentes celulares: Linfocitos T y B.

- Componentes humorales: Inmunoglobulinas, interleuquinas e interferón gama. 
Figura 1.5. Relación entre la inmunidad innata y adaptativa en las tres líneas de defensa del organismo frente a los patógenos.

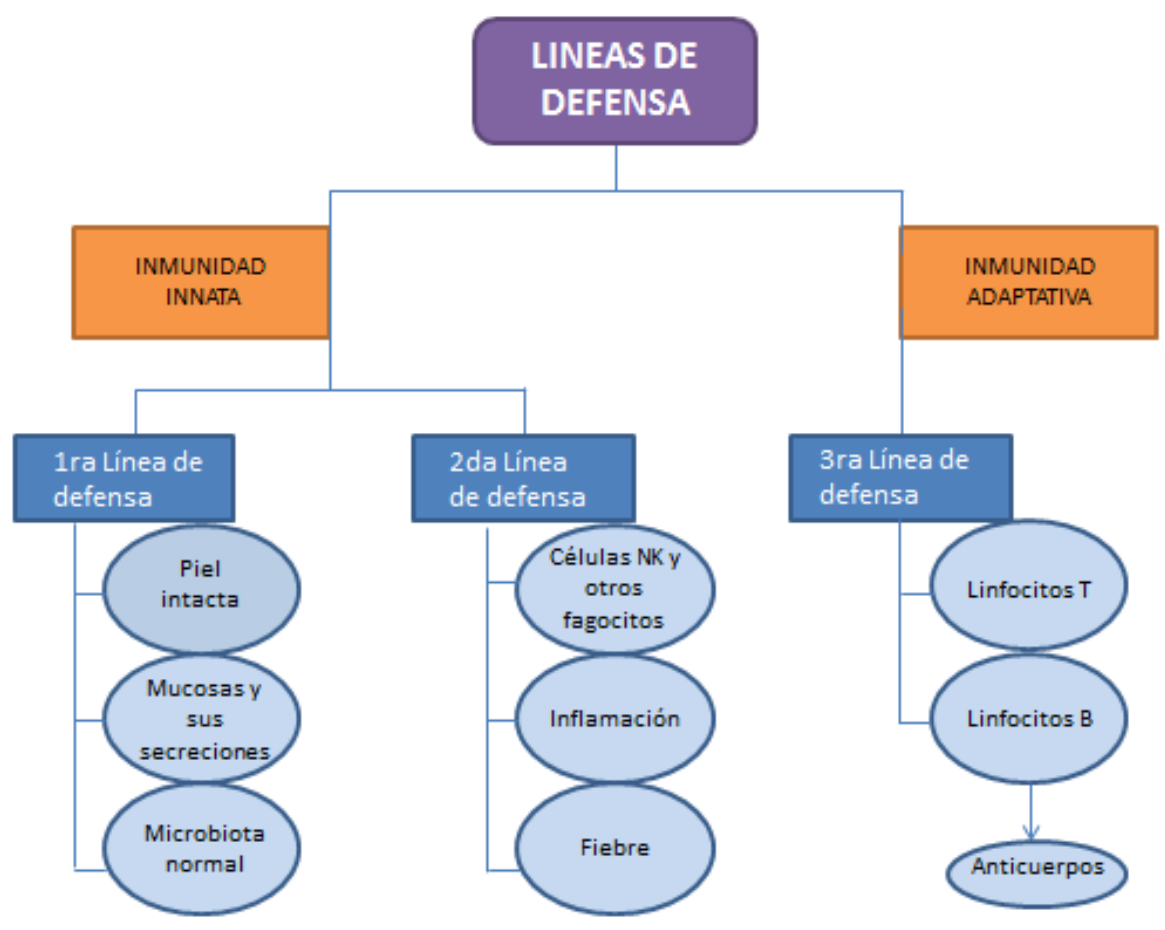

La respuesta inmune innata resuelve o al menos controla el proceso infeccioso naciente hasta el desarrollo de la respuesta inmune adaptativa. Esta respuesta se inicia cuando las células presentadoras de antígenos (CPA; por ejemplo: célula dendrítica) migran del foco infeccioso a los órganos linfáticos secundarios (ejemplo, ganglio linfático regional) en donde los linfocitos $\mathrm{T}$ y $\mathrm{B}$ reconocerán el antígeno y sus clones se expandirán y se diferenciaran a las células efectoras de la inmunidad adaptativa (Fainboim, 2008).

\subsubsection{Complejo Mayor de Histocompatibilidad (MHC)}

Dentro de los genes que participan en la respuesta inmune, los pertenecientes al Complejo Mayor de Histocompatibilidad (MHC) cumplen un rol central, tanto en la respuesta celular como humoral. Codifican para las glicoproteínas (superfamilia de las 
Inmunoglobulinas) de membrana responsables del fenómeno de restricción del sistema inmune. Hay dos clases principales de moléculas que difieren tanto en estructura (figura 1.6) como en distribución. Las moléculas de clase I, se encuentran en todas las células nucleadas, mientras que las moléculas de clase II se encuentran principalmente en las células presentadoras de antígenos (linfocitos $\mathrm{B}$, macrófagos y células dendríticas) y en otras células (Ej., epiteliales) dentro de lesiones inflamatorias. A diferencia de otras especies, los linfocitos $\mathrm{T}$ caninos (también los felinos) expresan constitutivamente moléculas de clase II en las primeras semanas de vida (Day, 2012).

Como se observa en la Figura 1.6, las moléculas de clase I están formadas por una cadena $\alpha$ compuesta por una cadena citoplasmática, una transmembrana y tres dominios externos y en una molecula de microglobulina $\beta_{2}$. La secuencia del dominio $\alpha_{3}$ se encuentra conservada en toda la superfamilia de Ig, mientras que los dominios $\alpha_{1 \text { y }} \alpha_{2}$ son variables.

Las moléculas de clase II consisten en dos cadenas transmembrana ( $\alpha$ y $\beta$ ), cada una con cuatro dominios externos, dos de secuencia conservada $\left(\alpha_{2}\right.$ y $\left.\beta_{2}\right)$ y dos de secuencia muy variable ( $\alpha_{1}$ y $\beta_{1}$; Figura 1.6). El sitio de reconocimiento de antígenos (ARS) consiste en un surco con un piso formado por una hoja plegada $\beta$ y dos paredes, cada una formada por una hélice $\alpha$. La selectividad de los alelos del MHC para unir péptidos es mediada por las propiedades bioquímicas de esos bolsillos (motivos aminoacídicos) ya que tienen un rol crítico en la unión del péptido. La afinidad de la unión del péptido a esos bolsillos estaría determinando la cantidad y calidad de la respuesta inmune. Trabajos previos analizaron la asociación entre la estructura proteica del MHC y el reconocimiento y la presentación de antígenos, esto puso en evidencia la importancia de estas moléculas en la respuesta inmune y la resistencia a las enfermedades infecciosas. Estos trabajos mostraron que la intensidad de la respuesta inmune es regulada por los motivos aminoacídicos de los sitios de unión a antígenos presentes en los bolsillos de las moléculas presentadoras del MHC (Konnai y col., 2003; Yoshida y col., 2009). 
Figura 1.6. Estructura de las moléculas de clase I y II. Clase I: moléculas de clase I . $\alpha_{1}, \alpha_{2}$ y $\alpha_{3}$ : tres dominios externos de la cadena $\alpha . \beta_{2} \mathrm{~m}$ : molécula de microglobulina. Clase II: moléculas de clase II. $\alpha_{1}$ y $\beta_{1}$ : dominios variables. $\alpha_{2}$ y $\beta_{2}$ : dominios conservados.

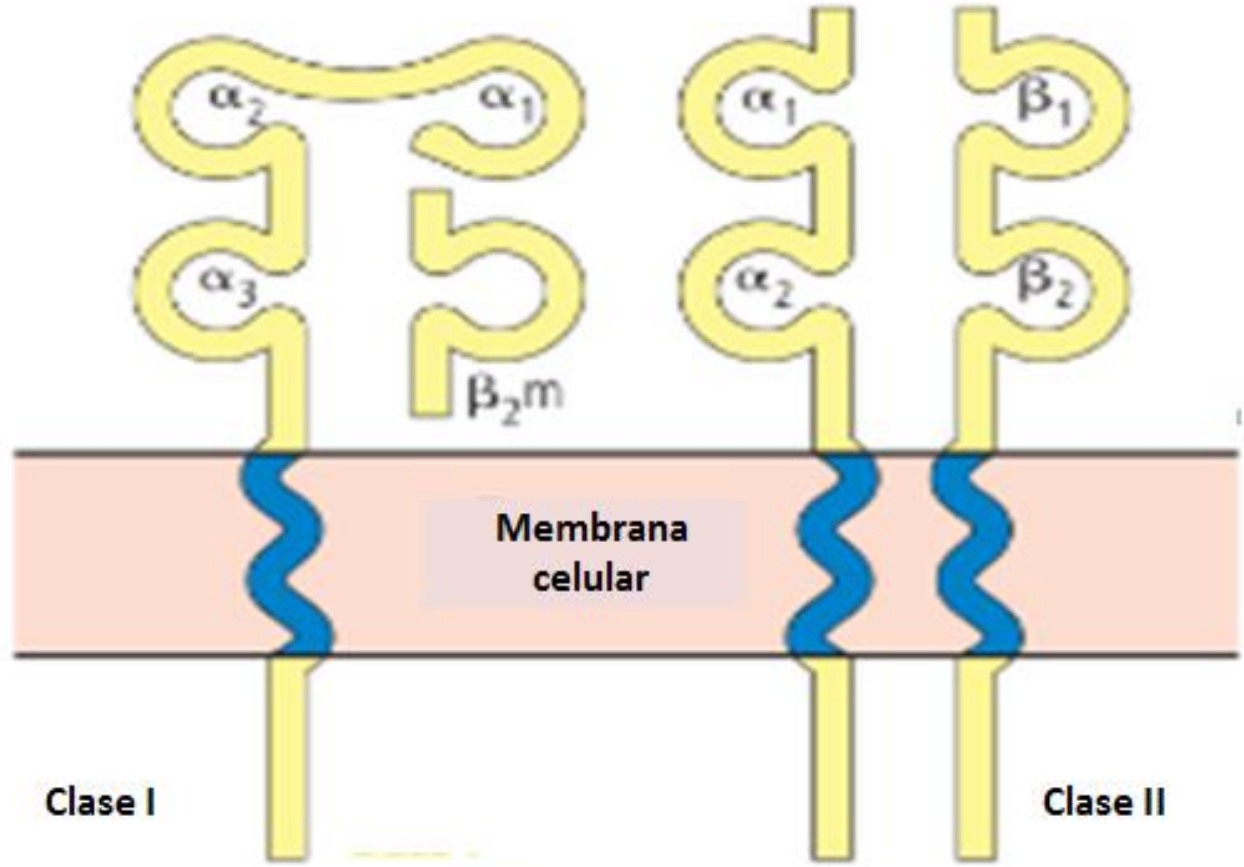

Citoplasma

El fenómeno por el cual los linfocitos $\mathrm{T}$ reconocen y responden a proteínas extrañas o propias y que son presentadas por las CPA se denomina restricción del MHC. A la conversión de proteínas a péptidos asociados al MHC se lo denominada procesamiento de antígenos. Las moléculas de clase I y II utilizan vías de procesamiento antigénico y de secreción diferentes (Figura 1.7).

Los linfocitos T CD4+ (helper o colaboradores), reconocen péptidos que se unen a moléculas de MHC de clase II en la superficie de las CPA (18-25 aminoácidos de tamaño). Los péptidos asociados a moléculas de clase II derivan usualmente de agentes patógenos extracelulares y de antígenos solubles. Los linfocitos T CD8+ (citotóxicos) reconocen fragmentos peptídicos unidos a moléculas de MHC de clase I (8-11 aminoácidos de tamaño). Los péptidos derivan fundamentalmente de proteínas endógenas sintetizadas (ej. Antígenos virales, tumorales) (Figura 1.8). 
Figura 1.7. Esquema del procesamiento y presentación de antígenos. 1) Antígeno intracelular (ej. Virus). 2) Antígeno Extracelular (ej. Bacterias). 3) Proteasoma (se procesa el antígeno y se reduce a péptidos que luego ingresaran en el retículo endoplasmático RE). 4) Vesícula endocítica. 5) Fagolisosoma (se procesa antígeno y se reduce a péptidos). 6) Molécula de MHC de clase II se une al péptido correspondiente. 7) Vesícula con receptor MHC de clase II. 8) MHC de clase II presenta el péptido antigénico en la superficie celular. 9) Molécula de MHC de clase I. 10) Unión del péptido a la molécula de MHC de clase I. 11) Molécula de clase I presenta el péptido antigénico en la superficie celular.

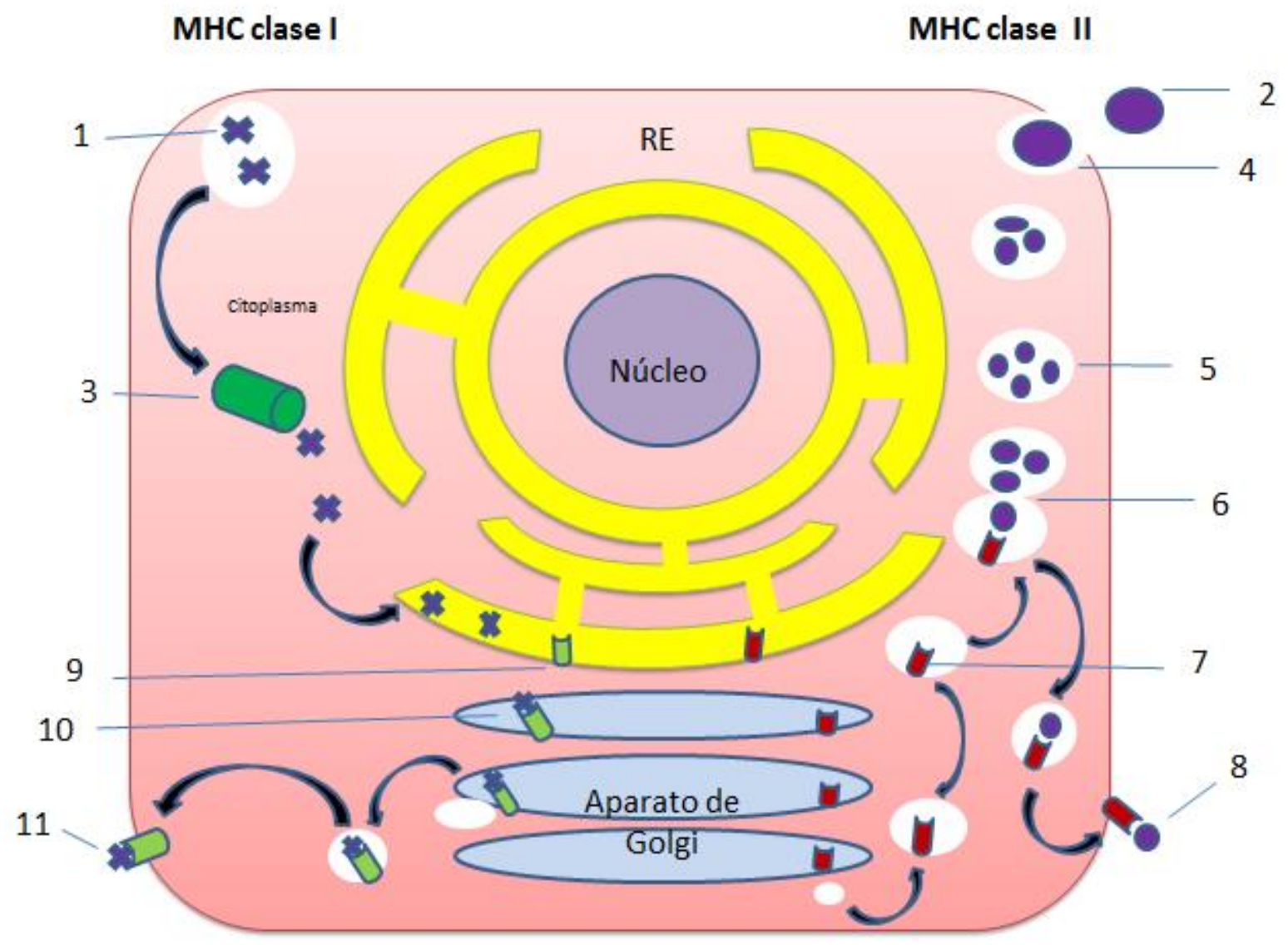


Figura 1.8. Función de las moléculas de clase II en la presentación de antígenos. TCR (Receptor en el linfocito T). APC (Célula presentadora de Antígenos, CPA)

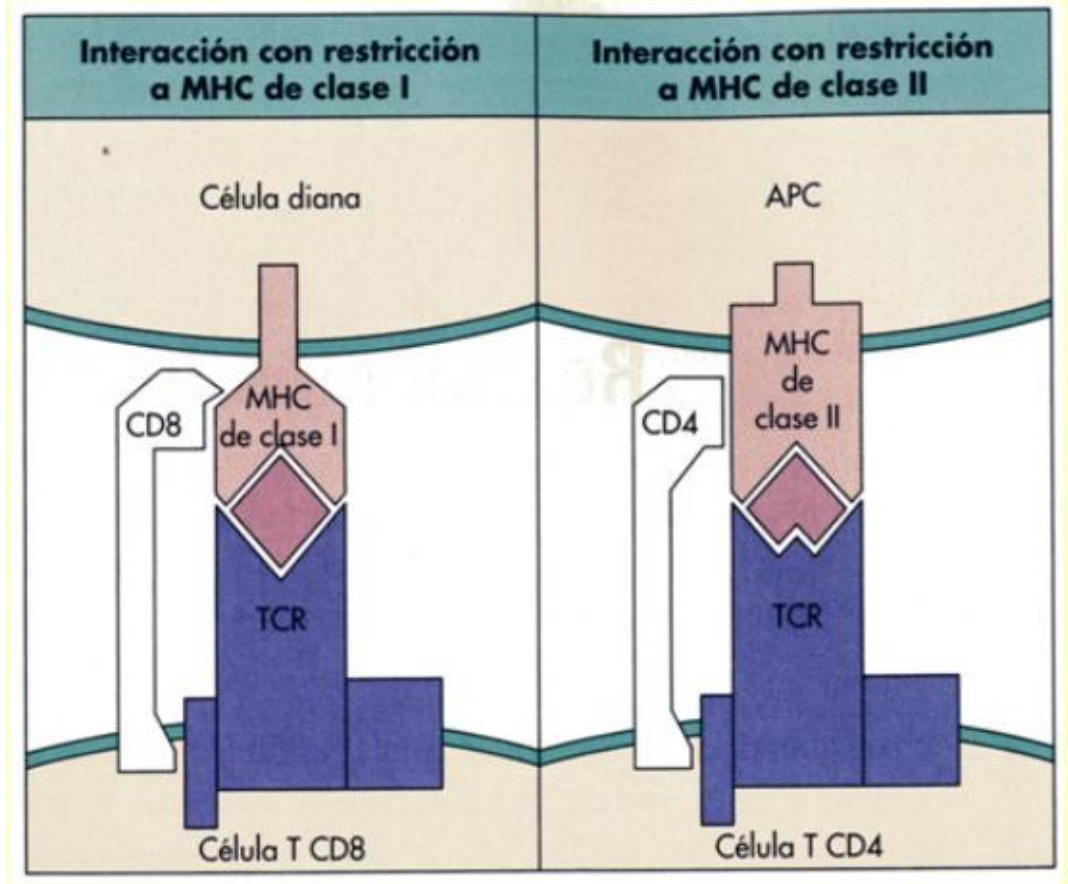

Al igual que el MHC de todos los mamíferos estudiados hasta la actualidad, el DLA está constituido por genes de clase I, II y III (Figura 1.9 y Tabla 1.4). El MHC canino, denominado Dog Leucocyte Antigen (DLA), ha sido mapeado en el cromosoma 12, entre las posiciones 892.380 y 2.383 .828 pb (http://www.ensembl.org/Canis_familiaris) (Figura $1.10)$. 
Tabla 1.4. Organización molecular del Complejo Mayor de Histocompatibilidad canino (Basado en el artículo: Molecular Organization of the Canine Major Histocompatibility. Complex. J. L. WAGNER, 2003.Journal of Heredity 2003:94(1):23-26)

a) Genes de clase I

\begin{tabular}{ccc}
\hline Nombre del Locus & Tipo de gen & Localización \\
\hline DLA-88 & Completo & CFA12 \\
DLA-79 & Completo & CFA18 \\
DLA-12 & Completo & CFA12 \\
DLA-64 & Completo & CFA12 \\
DLA-12a & Pseudogén & CFA12 \\
DLA-53 & Pseudogén & CFA12 \\
DLA-A & - & CFA12 \\
C1pg-26 & - & - \\
\hline
\end{tabular}

b) Genes de clase II

\begin{tabular}{cll}
\hline Nombre del Locus & Tipo de gen & Localización \\
\hline DLA-DRA1 & Completo & CFA12 \\
DLA-DRB1 & Completo & CFA18 \\
DLA-DRB2 & Pseudogén & CFA12 \\
DLA-DQA1 & Completo & CFA12 \\
DLA-DQB1 & Completo & CFA12 \\
DLA-DQB2 & Pseudogén & CFA12 \\
DLA-DPA1 & - & - \\
DLA-DPB1 & - & - \\
DLA-DPB2 & - & - \\
DLA-DOB & - & - \\
LMP-2 & - & - \\
\hline
\end{tabular}

c) Genes de clase III

\begin{tabular}{cll}
\hline Nombre del Locus & Tipo de Gen & Localización \\
\hline C4 $_{3}$ & Completo & CFA12 \\
${\text { TNF- } \alpha_{4}}_{\text {HSP-70 }_{5}}^{\text {Completo }}$ & Completo & CFA12 \\
\hline
\end{tabular}

1) Secuencia nucleotídica similar a un gen funcional normal que no da como resultado un producto, es decir, que no se expresa. 2) Low molecular weight polypeptide. 3) Componente 4 del complemento. 4) Factor de necrosis tumoral alfa. 5) Heat shock proteins. 
Los genes que codifican para las moléculas del MHC se encuentran juntos en un cluster en el cromosoma 12 canino. En el humano se han mapeado y consisten en genes de clase I (A, B y C) y de clase II que codifican a las cadenas $\alpha$ y $\beta$ (D). Entre estos loci hay una serie de genes (clase III) que codifican para algunas proteínas del complemento (c2, c4 y factor B), la enzima 21-hidroxilasa, proteínas de shock térmico y el factor de necrosis tumoral (TNF), entre otros. El MHC canino, al igual que todos los mamíferos estudiados hasta la actualidad, tiene una estructura similar (Day, 2012; Figura 1.9).

Figura 1.9. Estructura del Complejo Mayor de Histocompatibilidad de mamíferos (modificado de Day, 2012).

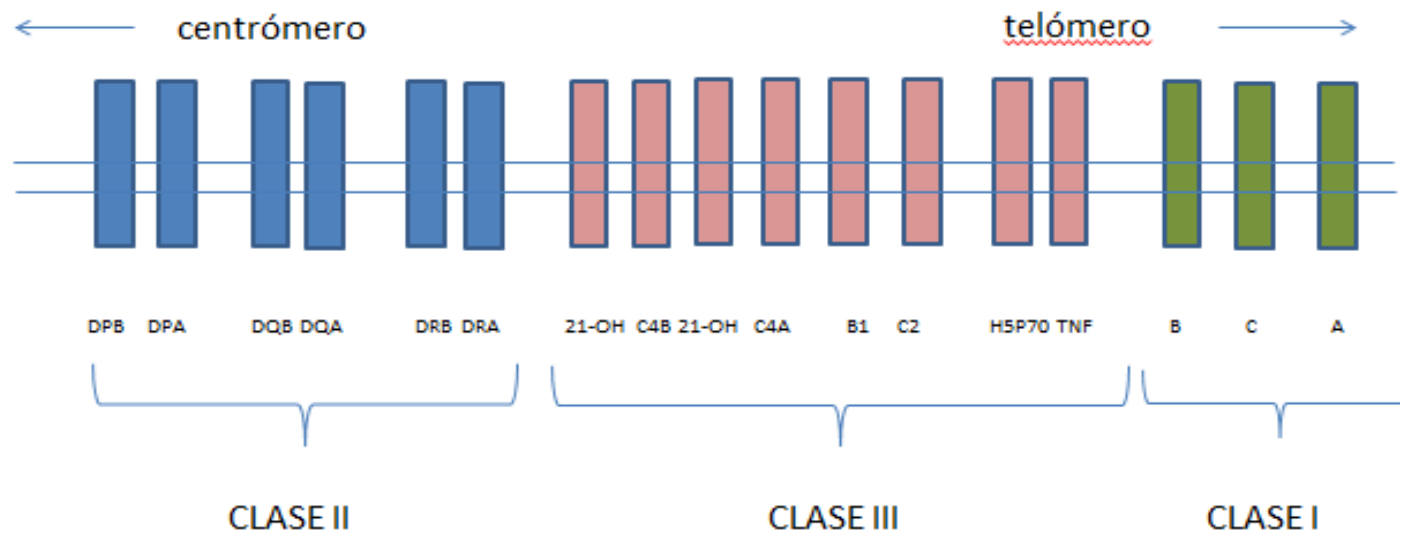

Las moléculas del Complejo Mayor de Histocompatibilidad de clase II (MHC clase II) son las más efectivas en la presentación de antígenos propios, los cuales activan a los linfocitos $\mathrm{T}$ autoreactivos. Por lo tanto, son los principales genes candidatos para estudiar las enfermedades autoinmunes (Day y Shultz, 2014). Estos genes desempeñan un importante rol en la resistencia/susceptibilidad tanto a enfermedades autoinmunes como a infecciosas y parasitarias: tales como diabetes tipo 1, poliartritis, tiroiditis linfocítica, anemia hemolítica inmuno-mediada, lupus eritematoso sistémico, demodicosis, 
leishmaniasis y streptococosis (Ollier y col., 2001; Kennedy y col., 2006; Kennedy y col., 2007; Wilbe y col., 2010; It y col., 2010; Quinnell y col., 2003; Kasper y col., 2014).

Figura 1.10 Región donde se ubican los genes DLA de clase II en el Cromosoma 12 canino utilizados en este estudio.(http://www.ensembl.org/Canis_familiaris)

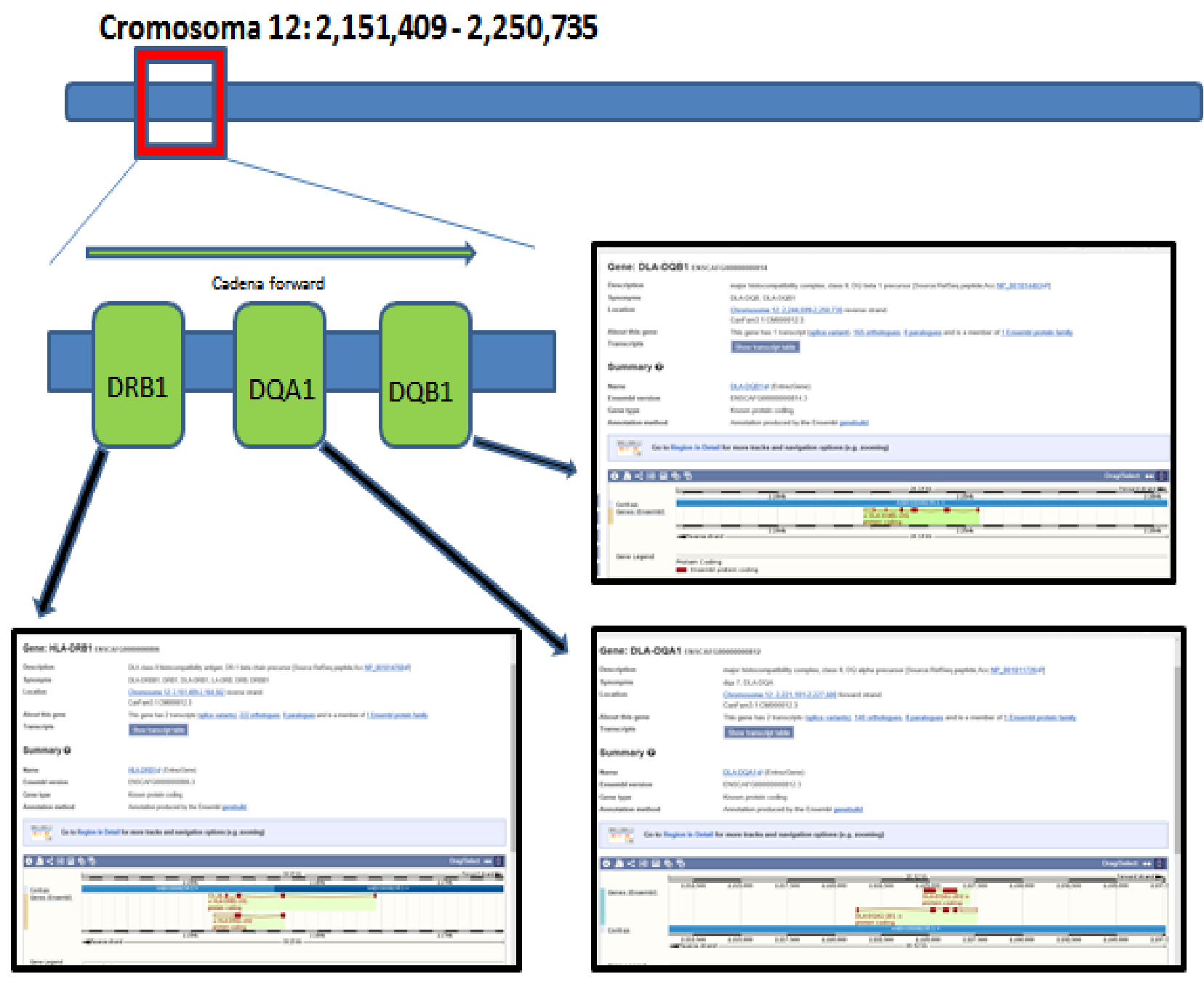




\subsection{Mapeo de Genes Asociados a Características Fenotípicas}

\subsubsection{Definición de marcador genético}

Los marcadores genéticos son variaciones (mutaciones) en la secuencia de ADN que presentan un modo de herencia conocido $\mathrm{y}$ son relativamente fáciles de identificar. Generalmente presentan una posición conocida dentro del genoma y son analizados mediante técnicas moleculares. Estas mutaciones pueden estar ubicadas dentro de la secuencia de un gen responsable de cierto fenotipo o ligadas a loci cuantitativos o cualitativos de interés. Estos locus deben ser polimórficos para ser informativos. Según Lucotte (1977), en una población se puede considerar un determinado locus como polimórfico cuando la frecuencia del alelo más común es igual o inferior a 0,99. Según el tipo de cambio ocurrido los polimorfismos pueden clasificarse en: polimorfismo de nucleótido simple (SNP), inserciones o deleciones de una o varias bases nucleotídicas (INDELs), variaciones en el número de repeticiones de secuencias en tándem (microsatélites), etc.

\subsubsection{Diseños experimentales utilizados para mapeo de genes asociados a caracteres fenotípicos}

Estudio de asociación Caso-Control: Consiste en detectar los marcadores genéticos relacionados al mayor o menor riesgo a desarrollar una enfermedad, determinando si se observan diferencias significativas entre los animales enfermos y los sanos. Se pueden hacer basados en genes candidatos funcionales, es decir, cuando el mismo se encuentra involucrado en la patogenia de la enfermedad (por ejemplo la asociación entre las variantes del gen del factor de von Willebrand y la enfermedad de von Willlebrand (Kramer y col., 2004) o sin tener en cuenta esa información a través de estrategias de rastreo genómico del tipo de:

Microsatélites: Fueron los primeros en utilizarse como marcadores posicionales debido al elevado desequilibrio de ligamiento con los genes responsables de la enfermedad 
(por ejemplo la asociación con un panel de microsatélites y la toxicosis por cobre en perros Bedlington Terriers permitió localizar el gen responsable de la enfermedad (YuzbasiyanGurkan y col., 1997)

SNP array: Es un tipo de DNA microarray utilizado para detectar SNPs dentro de una población. Luego de haberse reportado el genoma completo canino en 2004 se utilizaron como herramientas para los estudios de asociación los SNPs distribuidos en el genoma a través de los SNPs array y los estudios de asociación llamados GWAS (Genome wide association). Los primeros estaban conformados para tipificar 1500 SNP y luego fueron aumentando la resolución (50k Affymetrix, 22k Illumina, $173 \mathrm{~K}$ Illumina HD array).

NGS (next generation sequencing): Las plataformas NGS realizan secuenciación de millones de pequeños fragmentos de ADN en paralelo. Las miles de millones de bases del genoma se secuencian varias veces. Esta tecnología puede utilizarse para secuenciar genomas enteros o restringidos a áreas específicas de interés incluyendo todos los genes codificantes (exoma completo) o un pequeño número de genes individuales.

\section{Estudio de Asociación por desequilibrio de ligamiento}

El mapeo de genes por desequilibrio de ligamiento (LD) se basa en asociaciones a nivel poblacional entre los alelos en los loci de la enfermedad y los marcadores cercanos. Estas asociaciones se producen generalmente cuando todos o la mayoría de los alelos de la enfermedad poseen un origen ancestral común (de la Chapelle, 1998).

\subsection{Queratitis superficial crónica en ovejero alemán}

La Queratitis Superficial Crónica (QSC) canina es una enfermedad inflamatoria no ulcerativa del estroma corneal superficial, que potencialmente puede producir ceguera. También es conocida como Pannus del Ovejero Alemán, Síndrome de Uberreitier y Pannus degenerativo (Whitley y Gilger, 1999). El Ovejero Alemán es la raza más comúnmente afectada. La edad de inicio y la raza de los animales afectados son de valor pronóstico en esta enfermedad (Whitley y Gilger, 1999). La QSC se describe como una queratitis linfocítica-plasmocítica, con una lesión similar a la del lupus discoide que se produce en la piel (Gelatt, 1999). Estudios previos han intentado sin éxito atribuirle una causa infecciosa. 
La lesión se desarrolla como una infiltración progresiva bilateral de células mononucleares en la región temporal del limbo del estroma corneal superficial (Bedford y Longstaffe, 1981). La fibroplasia progresiva y la vascularización que se produce, a menudo conduce a la participación de toda la extensión de la córnea. Los casos clínicos parecen ser más graves a medida que aumenta la altitud y en climas más cálidos, lo que sugiere una modulación actínica de la enfermedad (Chandler y col., 2008).

El patrón difuso de las manchas y la ausencia de éstas en estructuras específicas del epitelio indicaría que la QSC no es una enfermedad autoinmune clásica similar a cualquier enfermedad del grupo pénfigo o el lupus eritematoso sistémico. Aunque las evidencias disponibles indicarían que la QSC sería una enfermedad inmuno-mediada (Chavkin y col., 1994).

La predisposición racial y los signos clínicos suelen ser suficientes para diagnosticar la QSC. Esta enfermedad generalmente es tratada por una variedad de métodos médicos y quirúrgicos, pero no es curada. Los propietarios deberían ser advertidos de la necesidad de una terapia de por vida para controlar la enfermedad y que tanto la severidad y como el pronóstico dependen de muchos factores, incluidos edad de inicio, altitud y localización geográfica (Williams, 1999).

\subsubsection{Incidencia y prevalencia de la enfermedad en la región y en el mundo}

La QSC ocurre con mayor frecuencia, pero no exclusivamente, en el perro Ovejero Alemán. La prevalencia de la QSC se correlacionó significativamente $(r=0,90)$ con la altitud de residencia, pero no con otros factores tales como la latitud y longitud geográfica, media anual de radiación solar y media anual de humedad relativa (Farmer ,1983). Los perros que viven en altitudes $>2.000$ metros sobre el nivel del mar fueron 7,75 veces más propensos a desarrollar lesiones que los que viven a alturas entre 900 y 1500 metros. Un estudio basado en los registros médicos de perros con $(n=595)$ y $\sin (n=72.877)$ QSC pertenecientes al Hospital Escuela de Veterinaria de la Universidad de Colorado (USA) determinó que las razas con mayor incidencia de QSC eran el Pastor Belga Tervuren, el Ovejero Alemán, el Border Collie, el Galgo, el Siberian Husky y el Pastor Australiano. Además, se evidenció que los perros de entre 4 y 7 años de edad tuvieron 2,36 veces más 
probabilidades de desarrollar lesiones que los perros menores a 4 años de edad (Chavkin y col., 1994).

\subsubsection{Estado del arte sobre la herencia de la QSC}

Se ha sugerido que QSC tendría una herencia recesiva con expresión variable (Gough y Thomas, 2004). Otro autor propuso para la raza galgo el modo autosómico dominante (Cheng y col, 2016).

Sin embargo, aún no se han reportado mutaciones causales de dicha enfermedad en las bases de datos públicas sobre enfermedades de origen genético en animales domésticos (Online Medelian Inheritance in Animals, http:/www.ncbinlm.nih.gov/omia; List of Inherited Diseases in Animals, http://sydney.edu.au/vetscience/lida/). Trabajos previos han descripto las características histopatológicas inflamatorias de la QSC (Gelatt, 1999; Chavkin y col., 1994), y puesto en evidencia el predominio de linfocitos CD4+ que se expresan en las lesiones (Williams, 1999). Además, la respuesta a los corticoides tópicos y a la ciclosporina apoya la hipótesis de que la QSC es una enfermedad inmuno-mediada. El centro normal de la córnea tiene bajos niveles de expresión de genes del Complejo Principal de Histocompatibilidad (MHC) de clase II. Por el contrario, en los animales con QSC presentan un considerable aumento en la expresión de estos genes, asociada a la secreción de interferón gamma por el infiltrado de linfocitos CD4+. Aunque este cambio es probablemente una característica secundaria de las lesiones producidas por la QSC, el aumento de la expresión de los genes del MHC de clase II puede jugar el papel fundamental para perpetuar la queratitis característica esta enfermedad (Williams, 2005).

Dadas las asociaciones previas reportadas entre citoquinas, tales como el interferón gamma, y la regulación positiva de la expresión de antígenos del MHC de clase II, Williams (2005) comparó la expresión de los antígenos de clase II en la córnea canina normal y afectada. Además, estudió el efecto in vitro del interferón gamma sobre la regulación positiva de la expresión de los antígenos del $\mathrm{MHC}$ de clase II en la córnea canina. Estos estudios demostraron que en la córnea normal los genes del MHC de clase II se expresan a altos niveles dentro del estroma y del epitelio del limbo de la córnea y el epitelio conjuntival, mientras presentan bajos nivel de expresión en la región central. Las 
células del limbo y del epitelio conjuntival que expresaron estos genes mostraron actividad ATPasa, lo que sugiere que son células de Langerhans. Por el contrario, las corneas de los perros con QSC mostraron una expresión de genes del MHC de clase II asociada a células del estroma y, aunque algunas eran dendríticas, la mayoría eran linfocitos. Las células corneales epiteliales dentro de la lesión también expresaron en forma aberrante los genes del MHC de clase II. Explantes corneales expresaron genes del MHC de clase II en diversos niveles luego de diferentes períodos de incubación con interferón gamma. Mientras la córnea central normal presentaba bajos niveles de expresión, en la QSC se observaron elevados niveles de expresión aberrante asociados a la secreción de interferón gamma por el infiltrado de linfocitos CD4+.

Los genes del MHC clase II desempeñan un importante rol en la resistencia/susceptibilidad a enfermedades inmuno-mediadas, tales como diabetes tipo 1, poliartritis, tiroiditis linfocítica, anemia hemolítica inmuno-mediada, demodicosis y lupus eritematoso sistémico (Ollier y col.,2001; Kennedy y col.,2006; Kennedy, 2007; It y col., 2010; Wilbe y col.,2010). Dadas las características inmunológicas de la QSC, los genes del MHC de clase II u otros genes involucrados en la respuesta inmune son buenos candidatos para el estudio de las bases genéticas de esta enfermedad. Debido a la sobreexpresión de las moléculas de clase II que ha sido reportada, tanto las regiones reguladoras (promotores) como las presentadoras de antígenos (exón 2) pueden ser buenos marcadores para esta enfermedad. Berggren y Seddon (2005) han despcripto la variabilidad genética a nivel de lo promotores de los genes DLA de clase II. Por otro lado, Jokinen y colaboradores (2011) analizaron la asociación entre los genes de clase II DLA-DRB1, -DQA1 y -DQB1 y la susceptibilidad a la progresión de QSC en Ovejeros Alemanes, demostrando que ciertos haplotipos estaban asociados a un mayor riesgo de presentar la enfermedad. Estos resultados apoyarían la hipótesis que QSC tendría un origen autoinmune. 


\section{HIPÓTESIS}

La Queratitis Superficial Crónica canina es una enfermedad autoinmune que está asociada a los polimorfismos en los loci del MHC canino involucrados en la respuesta inmune.

\section{OBJETIVOS}

Objetivo General: El objetivo general del presente estudio consistió en identificar la asociación entre los polimorfismos de los genes de clase II y la predisposición a desarrollar Queratitis Superficial Crónica en perros de la raza Ovejero Alemán. Dicho objetivo general incluyó los siguientes objetivos específicos:

a) Estudiar la prevalencia de la QSC en la región.

b) Evaluar la influencia del sexo y edad sobre la prevalencia de QSC.

c) Asociar marcadores de tipo microsatélites ligados al cluster DLA con la susceptibilidad a desarrollar QSC.

d) Caracterizar los polimorfismos presentes en las regiones promotoras y en la región presentadora de antígenos (exón 2) de los genes de clase II DLA-DRB1, DLADQB1 y DLA-DQA1.

e) Desarrollar un software para determinar los haplotipos que definen los alelos de los DLA-DRB1，DLA-DQB1 y DLA-DQA1 tipificados mediante secuenciación directa.

f) Asociar los alelos de los genes DLA-DRB1, DLA-DQB1 y DLA-DQA1 con la predisposición a desarrollar QSC. 
2-MATERIALES Y MÉTODOS 


\section{2-MATERIALES Y MÉTODOS}

\subsection{Material animal.}

\subsubsection{Datos fenotípicos.}

Unidad de análisis: Perros de la raza Ovejero Alemán de provincia de Buenos Aires (Figura 2.1).

Diseño experimental: En el presente estudio se utilizó una estrategia de casocontrol. Este diseño retrospectivo y transversal consiste en dividir a la muestra en animales sanos y enfermos para luego evaluar las diferencias entre ambos grupos. Es por esta razón que la inclusión de los animales en cada grupo se llevó adelante según los siguientes criterios:

Grupo Caso: compuesto por perros Ovejeros Alemanes con QSC, clasificados por sexo y edad. Estos animales presentaban pérdida de transparencia corneal, reacción inflamatoria corneal bilateral originada en el ángulo ventro-temporal que progresa al centro corneal. Además, los perros enfermos presentaban las siguientes características en la región afectada: variación de color, dependiendo del progreso de la enfermedad (gris, rojo y/o marrón), vascularización subepitelial y pigmentación del área vascular (Figura 2.2). Los pacientes no presentaron signos de dolor ni inflamación palpebral. La inspección oftalmológica se realizó mediante biomicroscopía con lámpara de hendidura (Kowa SL-14, Japón). Para descartar la presencia de la queratoconjuntivitis seca se midió la producción de lágrimas mediante el test de Schirmer (Showa Yakuhin Kako, Tokio, Japón). Además, se completó la inspección con oftalmoscopio indirecto (oftalmoscopio indirecto, All Pupil, Keeler, Inglaterra y lupa Volk 20) para evaluar el segmento posterior en aquellos pacientes en los que la opacidad corneal no permitía la evaluación directa (ANEXO 1). 
Figura 2.1. Perros de la raza Ovejero Alemán.

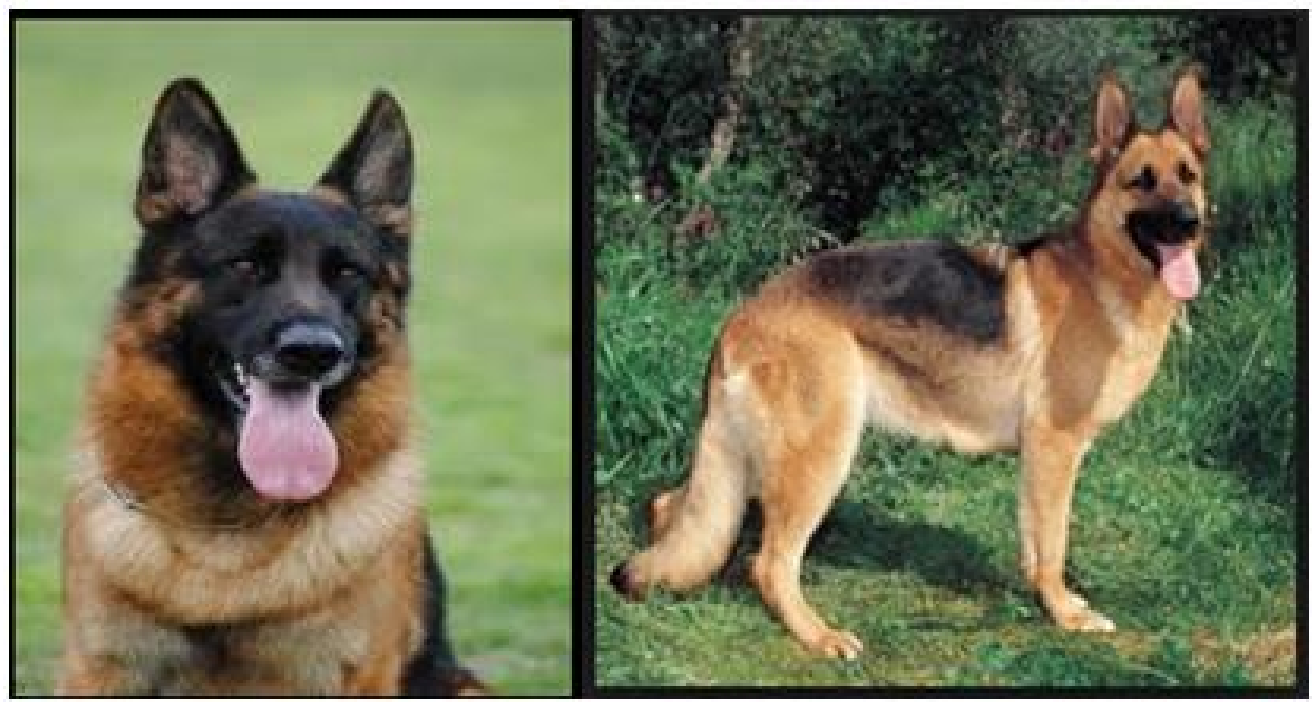

Figura 2.2. Signos característicos a la inspección oftalmológica. La lesión característica de la enfermedad es la reacción inflamatoria corneal bilateral originada en el ángulo ventrotemporal que progresa al centro corneal.

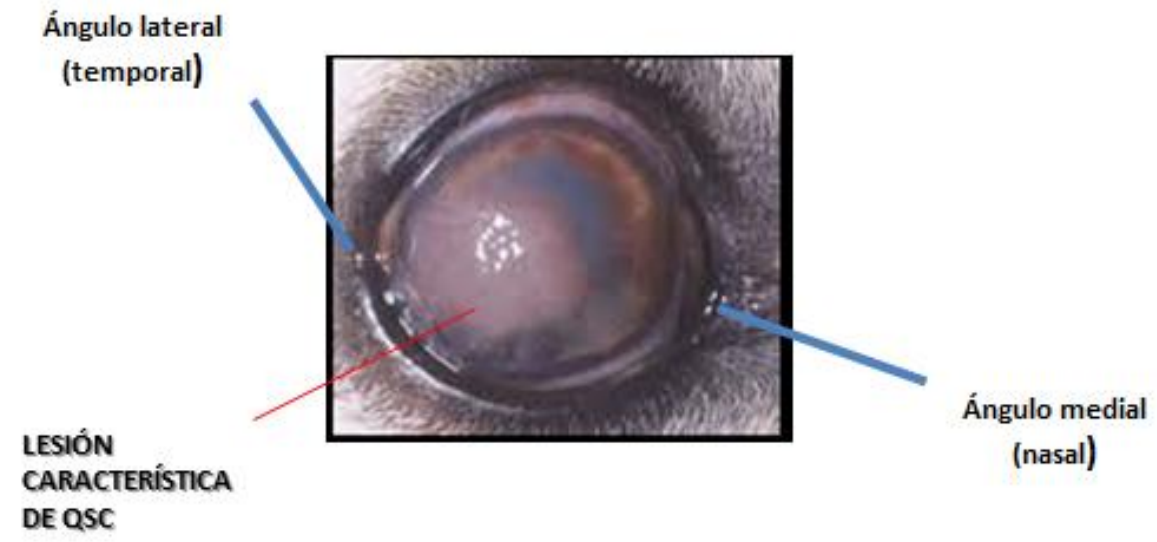


Grupo Control: compuesto por perros Ovejeros Alemanes sanos, clasificados por sexo y una edad mayor a 8 años. Estos animales no presentaron alteraciones corneales durante el estudio oftalmológico a pesar de su avanzada edad.

\subsubsection{Población estudiada.}

Se evaluaron un total de 73 animales, los que se clasificaron en grupo caso $(\mathrm{N}=43)$ y grupo control $(\mathrm{N}=30)$ según los criterios antes mencionados. La proporción entre enfermos y sanos fue de 1,43:1 y la relación entre hembras y machos de 1,21:1. El grupo CASO (enfermos) tuvo un relación hembra:macho de 1,15:1 y el promedio de edad fue de 5,5 años. El grupo CONTROL (sanos) tuvo una relación hembra: macho de 1,3:1 y un promedio de edad de 10,5 años. Como se mencionó anteriormente, la mayor edad promedio de este último grupo se debió a que sólo se incluyeron animales mayores de 8 años.

\subsection{Obtención de la muestra y extracción de ADN.}

Se tomaron muestras de sangre entera de la vena cefálica antebraquial o safena en un tubo con ácido etilediaminotetraacético (EDTA) al 6\% como anticoagulante, previa firma del consentimiento informado a los propietarios (ANEXO 2). El ADN genómico se extrajo a partir de las muestras de sangre con el kit de purificación de ADN genómico Wizard (Promega, Madison, WI, USA), de acuerdo a las instrucciones del proveedor (ANEXO 3 ). Luego de la extracción se midió cantidad y calidad del ADN genómico obtenido utilizando espectrofotometría (ANEXO 5).

\subsection{Genotipificación.}

En el presente estudio se utilizaron tres tipos de marcadores genéticos: microsatélites, SNPs e INDELs. A continuación se describen las metodologías utilizadas para su genotipificación (Figura 2.3). 
Figura 2.3. Descripción esquemática de la metodología utilizada para la genotipificación de las muestras.
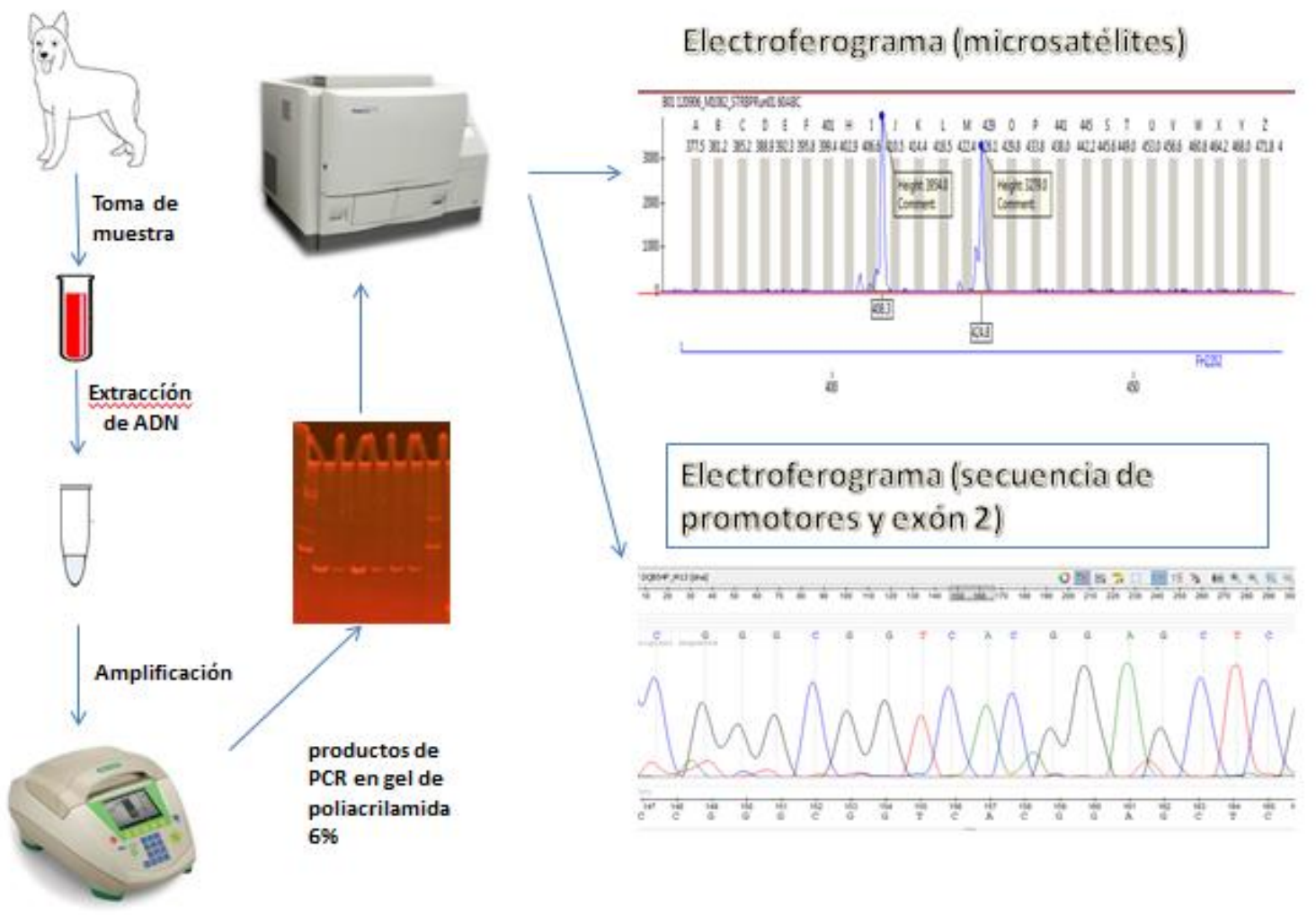

[TERMOCICLADOR]

\subsubsection{Microsatélites}

Los animales se tipificaron para tres microsatélites ligados a los genes DLA mediante la técnica de análisis de fragmentos, la que contempla una primera etapa de amplificación del microsatélite por PCR utilizando primers fluorescentes, seguido de una electroforésis capilar en un secuenciador de ADN. Finalmente, los genotipos son identificados mediante los picos de fluorescencia (Figura 2.3). Como se observa en la Figura 2.4, dichos 
marcadores se encuentran localizados en diferentes regiones del DLA. Las características de los tres marcadores utilizados se describen en la Tabla 2.1.

Tabla 2.1. Características de los microsatélites FH2054, FH2975 y FH2202 utilizados en el presente estudio.

\begin{tabular}{|c|c|c|c|c|c|}
\hline Locus & Unidades de & Posición & Rango de & Primers Se & encia $5^{\prime}-3^{\prime}$ \\
\hline FH2054 & $\begin{array}{l}\text { Tetranucleótido } \\
(\text { GATA })_{n}\end{array}$ & 4747 & $140-184$ & $\begin{array}{l}\text { Forward } \\
\text { Reverse }\end{array}$ & $\begin{array}{l}\text { GCCTTATTCATTGCAGTTAGGG } \\
\text { ATGCTGAGTTTTGAACTTTCCC }\end{array}$ \\
\hline FH2202 & $\begin{array}{l}\text { Tetranucleótido } \\
(\text { AAGA })_{n}\end{array}$ & 600 & $377-477$ & $\begin{array}{l}\text { Forward } \\
\text { Reverse }\end{array}$ & $\begin{array}{l}\text { GTTGAGTGGTTGCCTTTAGC } \\
\text { CAGGATCTTCATATGTCACC }\end{array}$ \\
\hline FH2975 & $\begin{array}{l}\text { Tetranucleótido } \\
(\mathrm{CTTT})_{\mathrm{n}}\end{array}$ & 13159 & $274-388$ & $\begin{array}{l}\text { Forward } \\
\text { Reverse }\end{array}$ & $\begin{array}{l}\text { TGAACCAATTGAGGAACACA } \\
\text { TGGGGTCTTGAGTTTGAGTC }\end{array}$ \\
\hline
\end{tabular}

Las reacciones de PCR se realizaron en un volumen total de $25 \mu 1$ de una solución de reacción que contenía $20 \mathrm{mM}$ de Tris- $\mathrm{HCl}(\mathrm{pH}=8,4), 50 \mathrm{mM}$ de $\mathrm{KCl}, 1,5 \mathrm{mM}$ de $\mathrm{MgCl}$, $200 \mu \mathrm{M}$ de dNTPs, 0,5 U de Taq polimerasa (Invitrogen, Carlsbad, CA), 0,4 $\mu \mathrm{M}$ de cada primer y entre 25-50 ng de ADN. Las condiciones de reacción fueron: 1 ciclo de 3 minutos a $95^{\circ} \mathrm{C}, 35$ ciclos de 40 segundos a $95^{\circ} \mathrm{C}, 1$ minuto a $61^{\circ} \mathrm{C}$ y 1 minuto a $72^{\circ} \mathrm{C}$ y una elongación final de 10 minutos a $72^{\circ} \mathrm{C}$.

Los productos de amplificación se verificaron en geles de poliacrilamida $6 \% 1 \mathrm{X}$ TBE durante 30 min a 170 voltios, se revelaron mediante la tinción con bromuro de etidio y se visualizaron en un transiluminador UV (Figura 2.3, ver ANEXO 6).

Con el fin de discriminar los alelos de los STRs, los productos de amplificación se corrieron en una electroforésis capilar utilizando un secuenciador automático de ADN MegaBACE 1000 (GE Healthcare, USA) usando como marcador de peso molecular el AQ4 ET550-R (GE Healthcare). (Figura 2.3). Los picos de fluorescencia y la asignación de los genotipos se llevó a cabo utilizando el software MEGABACE GENETIC PROFILER SOFTWARE SUITE version 2.2 (GE Healthcare). 
Figura 2.4. Localización en la región del DLA de clase II de los microsatélites utilizados en este estudio.

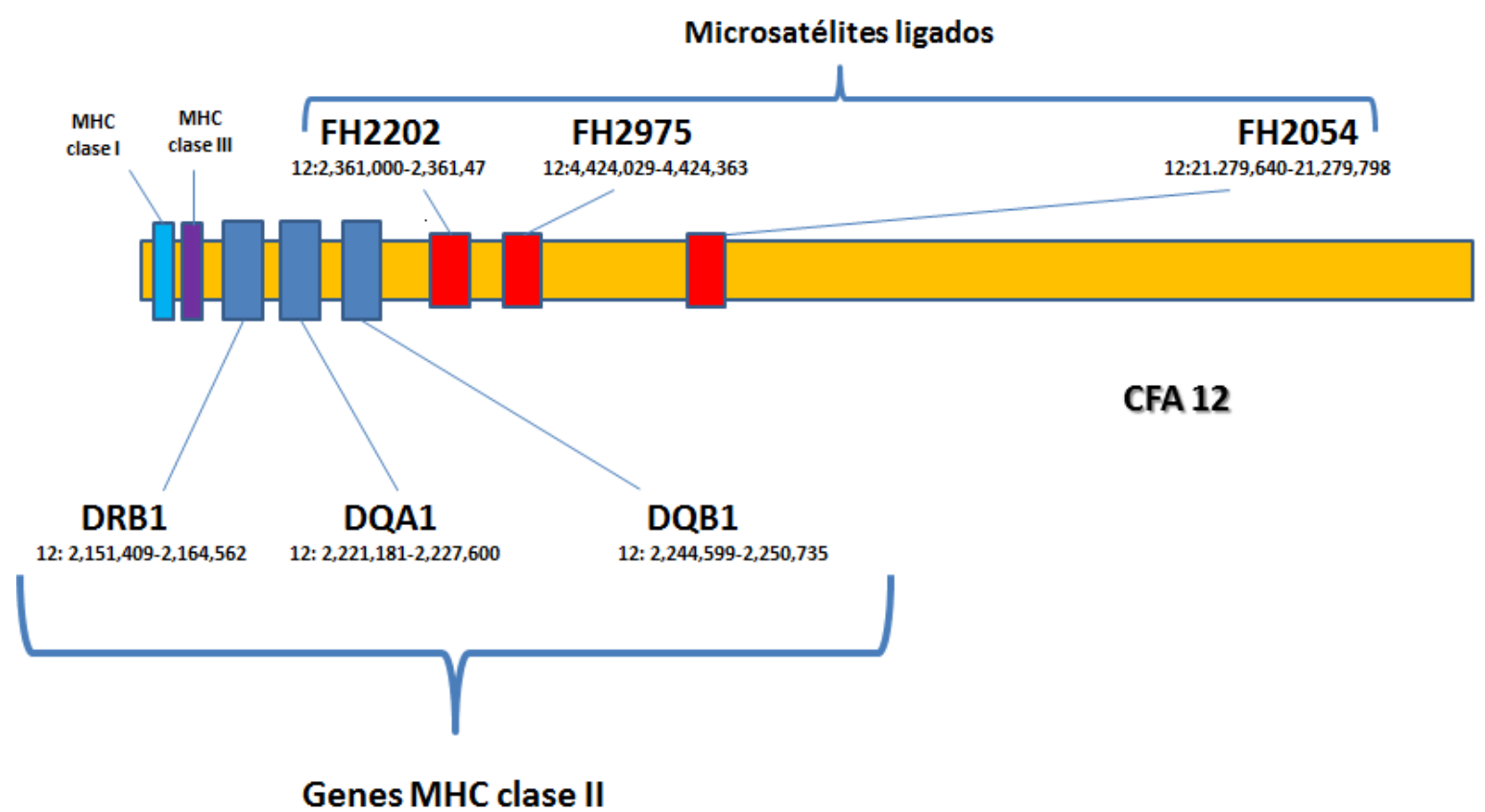

\subsubsection{Secuenciación}

Para el análisis de las regiones reguladoras y presentadoras de antígenos de genes de clase II del DLA se utilizó la metodología de secuenciación directa (SBT) mediante la técnica de Sanger (dideoxy chain termination method, Sanger y col., 1977). Este método se basa en un proceso de síntesis de ADN controlado por la adición de terminadores dideoxi marcados, ddNTPs, en una PCR. La ADN polimerasa copia el molde de ADN de cadena simple mediante la incorporación de nucleótidos en el extremo 3 'de un cebador hibridado al ADN molde. Se sintetiza una nueva cadena de ADN mediante la adición de un nucleótido al extremo 3'-hidroxilo. El método de Sanger explota la capacidad de las ADN polimerasas de incorporar análogos de nucleótidos, tales como didesoxinucleótidos (ddNTPs), y terminadores marcados con fluorescencia. Estos son nucleótidos que carecen del grupo 3'-hidroxilo libre (bloqueado por la marca fluorescente). Mediante la adición de terminadores, junto con dNTPs ordinarios, a la reacción, el proceso de alargamiento se 
termina una vez que un terminador se incorpora. Debido a que cada terminador lleva una marca fluorescente de color diferente, es posible detectar qué nucleótido dio por terminada la polimerización. Varias rondas de elongación generarán fragmentos de todos los tamaños. Estos fragmentos son posteriormente discriminados por electroforésis capilar, y la secuencia de nucleótidos se puede leer mediante la detección de fluorescencia después de que las marcas son excitadas por un rayo láser. Este análisis se realiza de forma rutinaria en secuenciadores automáticos, que suelen utilizar electroforésis capilar.

\subsubsection{Genes de clase II del Complejo Principal de Histocompatibilidad canino (DLA)}

Para realizar la caracterización genética de los genes de clase II DLA-DRB1, DLADQA y DLA-DQB se tipificaron por la técnica de PCR-secuenciación directa (SBT) los SNPs e INDELs presentes en dos regiones de estos loci: la región promotora proximal y el segundo exón o región presentadora de antígenos (ARS). La técnica utilizada consiste en la amplificación por PCR de la región a caracterizar, los amplicones (productos de PCR) se secuenciaron mediante la técnica de Sanger en un secuenciador capilar de ADN, finalmente los cromatogramas se procesaron y los polimorfismos se identificaron mediante software específicos (Figura 2.5). 
Figura 2.5. Cromatograma de un fragmento de $\mathrm{ADN}$. La altura de los picos está relacionada con el número de fragmentos que tienen el mismo largo y mismo nucleótido en el extremo 3'. El eje de las X es el tiempo en el cual ese grupo de fragmentos migra desde el sitio de siembra a la ventana del capilar del secuenciador donde es detectado por el láser y el sistema óptico.

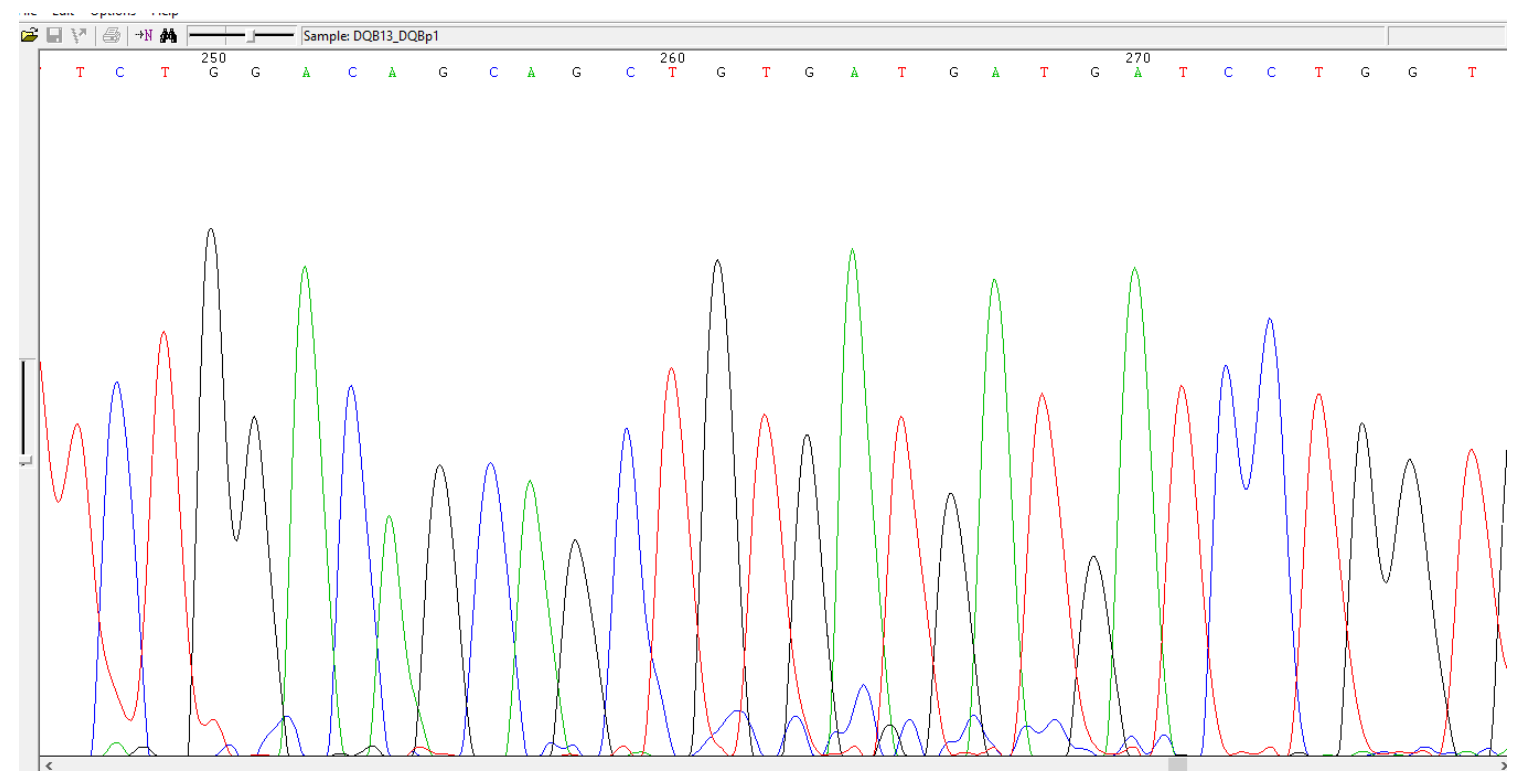

\subsection{3.a. Regiones reguladoras de los genes de clase II DLA-DRB1,-DQA1 y-DQB.}

Para caracterizar los polimorfismo de la región promotora proximal de los genes de clase II del DLA se amplificaron tres fragmentos de 219, 255 y 294 pb correspondientes a los genes DLA-DRB1, -DQA1 y -DQB1, respectivamente, utilizando los primers publicados por Berggren y Seddon (2005). Se utilizó la nomenclatura propuesta por estos autores para denominar los alelos de las regiones promotoras de estos genes de clase II. Las características de los tres marcadores tipificados se describen en la Tabla 2.2. 
Tabla 2.2. Primers utilizados para amplificar las regiones promotoras de los genes de DLA-DRB1, -DQA1 y-DQB1.

\begin{tabular}{llcl}
\hline Gen & Primers $\left(5^{\prime} \mathbf{3}^{\prime}\right.$ ) & $\begin{array}{c}\text { Tamaño del } \\
\text { amplificado }\end{array}$ & Región \\
\hline DRB1 & Forward CAATCCTTTCAATGAACAAAATCAAAG & $219 \mathrm{pb}$ & Promotor \\
& Reverse GTGTGCACTTACGTGGGGTGT & & \\
DQA1 & Forward ATTGATTGAGTGAGCCTCCTCCT & $255 \mathrm{pb}$ & Promotor \\
& Reverse TGTGCACTCACCCACAATCTC & & \\
DQB1 & Forward TTGTTCAGTTTCTTAAACCCCTAAGG & $294 \mathrm{pb}$ & Promotor \\
& Reverse AGGTGTCCTGCACTTACGTGG & & \\
\hline
\end{tabular}

Las reacciones de PCR se realizaron en un volumen total de $25 \mu \mathrm{l}$ de una solución de reacción que contenía $20 \mathrm{mM}$ de Tris- $\mathrm{HCl}(\mathrm{pH}=8,4), 50 \mathrm{mM}$ de $\mathrm{KCl}, 1,5 \mathrm{mM}$ de $\mathrm{MgCl}_{2}$, $200 \mu \mathrm{M}$ de dNTPs, 0,5 U de Taq polimerasa (Invitrogen, Carlsbad, CA), 0,4 $\mu \mathrm{M}$ de cada primer y entre 25-50 ng de ADN. Las condiciones de reacción fueron: 1 ciclo de 3 minutos a $94^{\circ} \mathrm{C}, 35$ ciclos de 30 segundos a $94^{\circ} \mathrm{C}, 40$ segundos a la temperatura de annealing correspondiente, 40 segundos a $72^{\circ} \mathrm{C}$ y una elongación final de 10 minutos a $72^{\circ} \mathrm{C}$.

Los productos de amplificación se verificaron en geles de poliacrilamida 6\% 1X TBE durante 30 min a 170 voltios, se revelaron mediante la tinción con bromuro de etidio y se visualizaron en un transiluminador UV (ANEXO 6). Posteriormente, los productos de PCR se purificaron mediante la técnica de precipitación diferencial con polietilenglicol 8000 (ANEXO 7) y se secuenciaron mediante el método de Sanger en un secuenciador automático de ADN MegaBACE 1000 (GE Healthcare, USA) usando el kit DYEnamic ET Terminator (GE Healthcare) (ANEXO 8 y 9). Las secuencias crudas fueron editadas mediante el software Sequence Analyzer (GE Healthcare). 
2.3.3. b. Regiones presentadoras de antígenos (exón 2) de los genes de clase II DLADRB1, -DQA1 y -DQB1.

Para caracterizar los polimorfismos de la región presentadora de antígenos (ARS) de los tres genes de clase II DLA-DRB1, DLA-DQA1 y DLA-DQB1 se amplificaron tres fragmentos de 270, 260 y $285 \mathrm{pb}$, respectivamente. Las características de los tres marcadores utilizados se describen en la Tabla 2.3. Vale la pena aclarar que el agregado a los primers específicos las secuencias de los primers universales (T7 promoter y M13 forward) permitió obtener secuencias de mejor calidad en los extremos y, por lo tanto, una lectura más eficiente de las mismas.

Tabla 2.3. Primers utilizados en la secuenciación del exón 2 de los genes DLA- DRB1, DLA-DQA1 y DLA-DQB1. Tm (Temperatura de Melting). M13 (M13(-21) forward). T7 (T7 promoter).

\begin{tabular}{|c|c|c|c|c|}
\hline Gen & Secuencia $5^{\prime}-3^{\prime}$ forward & Secuencia 5'-3'reverse & $\begin{array}{c}\text { Tm } \\
\left(C^{\circ}\right)\end{array}$ & Región \\
\hline DRB1 & $\begin{array}{l}\text { M13-CTC AGC TGA } \\
\text { CCA TGT TGC }\end{array}$ & $\begin{array}{l}\text { T7-GGG GAC AGA TTC } \\
\text { AGT GAA GAG A }\end{array}$ & $\begin{array}{l}67- \\
63^{\circ} \mathrm{C}\end{array}$ & Exón 2 \\
\hline DQA1 & $\begin{array}{l}\text { M13-CCG TCC CCA } \\
\text { CAG CAC ATT TC }\end{array}$ & $\begin{array}{l}\text { T7-GGT GTG TCA CAC } \\
\text { ACC TCA GCA CCA }\end{array}$ & $\begin{array}{l}69- \\
66^{\circ} \mathrm{C}\end{array}$ & Exón 2 \\
\hline DQB1 & $\begin{array}{l}\text { M13-CTC ACT GGC } \\
\text { CCG GCT GTC TC }\end{array}$ & $\begin{array}{l}\text { T7- GGC ACC TCG CCG } \\
\text { CTG CAA CGT G }\end{array}$ & $\begin{array}{l}68- \\
71^{\circ} \mathrm{C}\end{array}$ & Exón 2 \\
\hline $\begin{array}{r}\text { M13 }( \\
\text { T7 } \\
\end{array}$ & $\begin{array}{l}\text { forward } \\
\text { omoter }\end{array}$ & $\begin{array}{l}\text { Secuencia 5'-3' } \\
\text { AA ACG ACG GCC AGT } \\
\text { AC GAC TCA CTA TAG }\end{array}$ & & \\
\hline
\end{tabular}

Las reacciones de PCR se realizaron en un volumen total de $25 \mu 1$ de una solución de reacción que contenía $20 \mathrm{mM}$ de Tris- $\mathrm{HCl}(\mathrm{pH}=8,4), 50 \mathrm{mM}$ de $\mathrm{KCl}, 1,5 \mathrm{mM}$ de $\mathrm{MgCl}_{2}$, $200 \mu \mathrm{M}$ de dNTPs, 0,5 U de Taq polimerasa (Invitrogen, Carlsbad, CA), 0,4 $\mu \mathrm{M}$ de cada primer y entre 25-50 ng de ADN. Las condiciones de reacción fueron: 1 ciclo de 3 minutos 
a $94^{\circ} \mathrm{C}, 35$ ciclos de 30 segundos a $94^{\circ} \mathrm{C}, 40$ segundos a la temperatura de annealing correspondiente, 40 segundos a $72^{\circ} \mathrm{C}$ y una elongación final de 10 minutos a $72^{\circ} \mathrm{C}$.

Los productos de amplificación se verificaron en geles de poliacrilamida $6 \% 1 \mathrm{X}$ TBE corridos durante $30 \mathrm{~min}$ a 170 voltios, se revelaron mediante la tinción con bromuro de etidio y se visualizaron en un transiluminador UV (ANEXO 6). Posteriormente, los productos de PCR se purificaron mediante la técnica de precipitación diferencial con polietilenglicol 8000 (ANEXO 7) y se secuenciaron mediante el método de Sanger en un secuenciador automático de ADN MegaBACE 1000 (GE Healthcare, USA) usando el kit DYEnamic ET Terminator (GE Healthcare) (ANEXO 8 y 9). Las secuencias crudas se editaron mediante el software Sequence Analyzer (GE Healthcare).

\subsection{Análisis Bioinformáticos}

Para el análisis y detección de los genotipos de los marcadores microsatélites, se utilizó el software MEGABACE GENETIC PROFILER SOFTWARE SUITE version 2.2 (GE Healthcare). Las secuencias de ADN obtenidas de los promotores y de los exones 2 se alinearon utilizando el software DNAMAN. En el primer caso las variaciones se definieron por comparación directa con las secuencias reportadas en el Genbank. En el caso de los sitios heterocigotas se realizó el control individual de las secuencias de ADN con el software Chromas Lite v2.1.1 (Technelysium, http://technelysium.com.au/?page_id=13) y UGENE (Okonechnikov y col., 2012). Para el análisis de los exones 2, debido al mayor grado de polimorfismo, se desarrolló un software en colaboración con el equipo de bioinformática del IGEVET (Instituto de Genética Veterinaria, FCV, UNLP), el que se basa en los lenguajes Python y R. En principio se desarrolló un script en Python, utilizando la biblioteca BioPython, que lee las secuencias a partir del cromatograma en formato FASTA, permitiendo la notación $[\mathrm{A} / \mathrm{C}]$ para los SNP polimórficos y los alineamientos extraídos de la base de datos IPD-MHC (ANEXO 12, https://www.ebi.ac.uk/ipd/mhc/)

Para el análisis de desequilibrio de ligamiento entre los diferentes loci se utilizó el software PyPop (Python for Population Genomics) 0.7.0 (www.pypop.org). Este análisis permitió analizar los haplotipos conformados por los exones 2 de los genes DLA-DRB1, -DQA1 y DQB1. 


\subsection{Análisis poblacional.}

Las frecuencias alélicas y genotípicas para cada una de los marcadores genéticos utilizados (microsatélites, SNPs e INDELs) dentro de los grupos caso y control se calcularon con el software GENEPOP 4.0 (Rousset y col., 1997, Rousset, 2007). La diversidad genética se estimó mediante el número de alelos $\left(\mathrm{n}_{\mathrm{a}}\right)$, la heterocigosidad observada $\left(h_{\mathrm{o}}\right)$ y esperada $\left(\mathrm{h}_{\mathrm{e}}\right)$ para cada locus y la heterocigosidad promedio esperada sobre todos los locus. El número de alelos se determinó por conteo directo, mientras que la $h_{e} y_{o}$ se estimaron de acuerdo a la fórmula propuesta por Nei (1978) usando el software de análisis genéticos poblacionales ARLEQUIN 3.5 (Schneider y col., 2000). Las posibles desviaciones del equilibrio de Hardy-Weinberg (HWE) se estimaron para cada locus y para cada grupo mediante el índice $\mathrm{F}_{\mathrm{IS}} \mathrm{y}$ el test exacto de Fisher incluido en el programa

GENEPOP 4. El desequilibrio de ligamiento (fase de ligamiento) entre los marcadores genéticos se reconstruyó por el método bayesiano implementado en el software Phase v2.1.1 (Li y Stephens, 2003; Crawford y col., 2004) utilizando las opciones predeterminadas. Las fases y el desequilibrio de ligamiento entre los loci se visualizaron por medio del programa Haploview v3.31 (Barrett y col., 2005).

\subsection{Análisis de asociación.}

La asociación entre los alelos/haplotipos y la predisposición a desarrollar QSC se evaluó utilizando el modelo clásico de estudio caso-control. Utilizando el mismo modelo, también se evaluó la hipótesis de la asociación entre la elevada homocigosis y la QSC. El test exacto de Fisher, Odds Ratio y sus intervalos de confianza (IC) se calcularon por comparación de las frecuencias alélicas entre ambos grupos. Se incluyeron en el estudio los alelos más representados en la población, considerando como límite de corte una frecuencia alélica de 0,05. Los valores de p menores a 0,05 se consideraron significativos. El análisis estadístico se llevó a cabo utilizando el paquete de R epitools (http://www.r-project.org/). 


\section{3- RESULTADOS}




\section{3-RESULTADOS}

\subsection{Análisis de las características de la muestra utilizadas.}

En un estudio retrospectivo realizado en colaboración con Servicio de Clínica de Pequeños Animales, Hospital Escuela de la Facultad de Ciencias Veterinarias, Universidad Nacional de La Plata se recolectó información de pacientes caninos sobre edad, sexo, raza y motivos de consulta ( $\mathrm{n}=752$ ), en un período comprendido entre el año 2009 y 2011. Donde se observó una incidencia de la QSC de 5,46\% $(\mathrm{n}=41)$, dentro de este grupo de animales el $78 \%(n=32)$ eran de la raza ovejero alemán. La edad de presentación promedio fue 5,5 años. Dentro los caninos afectados, la relación hembra: macho fue de 1,15:1. No se observaron diferencias en la predisposición a desarrollar QSC entre hembras y machos (chi cuadrado $=0,2$, con un valor de $p=0,05$ y un valor crítico de 3,84 ).

En la muestra de perros ovejeros alemanes analizada en el presente estudio, se observó una relación entre enfermos y sanos de 1,43:1 y una relación entre hembras y machos de 1,21:1. El grupo CASO (animales enfermos) tuvo un relación hembra: macho de 1,15:1 y un promedio de edad de 5,5 años. El grupo CONTROL (animales sanos) tuvo una relación hembra: macho de 1,3:1 y un promedio de edad de 10,5 años. Cabe recordar que, como se mencionó anteriormente, la mayor edad promedio de este último grupo se debe a los criterios de inclusión empleados en el estudio.

\subsection{Análisis poblacional}

\subsubsection{Microsatélites ligados al DLA}

Para el análisis de los microsatélites FH2054, FH2975 y FH2202, se tipificaron un total de 61 animales (55 ovejeros alemanes, 3 mestizos, 1 galgo, 1 ovejero belga y 1 pastor suizo). Esta muestra se dividió en grupo caso $(\mathrm{n}=35,16$ hembras y 18 machos) y control ( $\mathrm{n}=26,15$ hembras y 7 machos), según los criterios descriptos en la sección "Material animal".

Para el microsatélite FH2054 se detectaron siete alelos en el total de la muestra, cuatro en el grupo control y siete en el grupo caso (Tabla 3.1). Las frecuencias alélicas de 
este marcador variaron entre 0,02 y 0,4. Esto resultó en valores de $h_{\mathrm{e}}$ de 0,732 y 0,722 y de $h_{o}$ de 0,56 y 0,661 en el grupo caso y en el grupo control, respectivamente (Tabla 3.2). El equilibrio HWE mostró que el grupo caso (estimado a partir del índice $\mathrm{F}_{\text {IS }}$ ) y en la población total (estimado mediante el método exacto de Fisher) no se ajustaban a las proporciones teóricas esperadas bajo el HWE (Tabla 3.2). Estos desvíos se debieron en los dos casos a un aumento significativo de individuos homocigotas. Por otra parte, no se observaron diferencias significativas en la proporción de individuos homocigotas entre los grupos caso y control $(\mathrm{p}<0,05)$.

Tabla 3.1. Frecuencias alélicas del microsatélite FH2054 (tetranucleótido) estimadas en los grupos caso y control.

\begin{tabular}{ccc}
\hline FH2054 (alelos) & CASO & CONTROL \\
\hline 148 & 0,06 & 0 \\
152 & 0,4 & 0,39 \\
156 & 0,06 & 0,12 \\
160 & 0,02 & 0 \\
164 & 0,15 & 0,14 \\
168 & 0,2 & 0,35 \\
172 & 0,11 & 0 \\
\hline
\end{tabular}

Tabla 3.2. Valores estimados de heterocigosidad esperada $\left(h_{e}\right)$ y observada $\left(h_{0}\right)$ para el microsatélite FH2054 detectados en los grupos caso y control y la población total.

\begin{tabular}{cccc}
\hline Grupo & $\mathbf{h}_{\mathbf{e}}$ & $\mathbf{h}_{\mathbf{0}}$ & F $_{\text {IS }}$ (valor de $\left.\mathbf{p}\right)$ \\
\hline CASO & 0,732 & 0,556 & $0,245(0,004)$ \\
CONTROL & 0,722 & 0,611 & $0,158(0,107)$ \\
Total & 0,746 & 0,578 & 0,003 \\
\hline
\end{tabular}

En cuanto al microsatélite FH2975 se detectaron 17 alelos en el total de la muestra, once en el grupo control y trece en el grupo caso (Tabla 3.3). Diez de estas variantes se detectaron sólo en uno de los grupos. Las frecuencias alélicas de este marcador variaron entre 0,01 y 0,35. Esto resultó en valores de $h_{\mathrm{e}}$ de 0,861 y 0,914 y de $h_{o}$ de 0,750 y 0,722 en el grupo caso y en el grupo control, respectivamente (Tablas 3.4). El equilibrio HWE 
mostró que en los dos grupos y en la población total no se ajustaba a las proporciones teóricas esperadas bajo el HWE (Tabla 3.4). En los tres casos los desvíos se debieron a un aumento significativo de individuos homocigotas. Además, no se observó un aumento significativo de homocigosis en el grupo caso con respecto al grupo control $(p<0,05)$, que podría llevar a la fijación de un alelo asociado al desarrollo de la enfermedad.

Tabla 3.3. Frecuencias alélicas del microsatélite FH2975 (tetranucleótido) estimadas en los grupos caso y control.

\begin{tabular}{ccc}
\hline FH2975 (alelos) & CASO & CONTROL \\
\hline $\mathbf{2 4 8}$ & $\mathbf{0 , 0 3}$ & $\mathbf{0}$ \\
$\mathbf{2 8 4}$ & $\mathbf{0}$ & $\mathbf{0 , 0 3}$ \\
$\mathbf{2 8 8}$ & $\mathbf{0 , 0 2}$ & $\mathbf{0}$ \\
$\mathbf{3 0 0}$ & $\mathbf{0 , 0 2}$ & $\mathbf{0 , 1 1}$ \\
$\mathbf{3 0 4}$ & $\mathbf{0 , 0 2}$ & $\mathbf{0}$ \\
$\mathbf{3 0 8}$ & $\mathbf{0 , 0 3}$ & $\mathbf{0}$ \\
$\mathbf{3 1 2}$ & $\mathbf{0 , 0 2}$ & $\mathbf{0 , 1 1}$ \\
$\mathbf{3 1 6}$ & $\mathbf{0}$ & $\mathbf{0 , 0 3}$ \\
$\mathbf{3 2 0}$ & $\mathbf{0 , 4 7}$ & $\mathbf{0 , 1 8}$ \\
$\mathbf{3 2 4}$ & $\mathbf{0 , 0 2}$ & $\mathbf{0 , 1 1}$ \\
$\mathbf{3 2 8}$ & $\mathbf{0}$ & $\mathbf{0 , 0 3}$ \\
332 & $\mathbf{0}$ & $\mathbf{0 , 0 8}$ \\
$\mathbf{3 4 0}$ & $\mathbf{0 , 0 7}$ & $\mathbf{0}$ \\
$\mathbf{3 4 4}$ & $\mathbf{0 , 0 7}$ & $\mathbf{0 , 1 3}$ \\
$\mathbf{3 4 8}$ & $\mathbf{0 , 1 7}$ & $\mathbf{0 , 0 5}$ \\
$\mathbf{3 5 2}$ & $\mathbf{0 , 0 5}$ & $\mathbf{0 , 1 6}$ \\
$\mathbf{3 5 6}$ & $\mathbf{0 , 0 2}$ & $\mathbf{0}$ \\
\hline
\end{tabular}

Tabla 3.4. Valores estimados de heterocigosidad esperada $\left(h_{e}\right)$ y observada $\left(h_{0}\right)$ para el microsatélite FH2975 detectados en los grupos caso y control y la población total.

\begin{tabular}{cccc}
\hline Grupo & $\mathbf{h}_{\mathbf{e}}$ & $\mathbf{h}_{\mathbf{0}}$ & $\mathbf{F}_{\text {IS }}($ valor de $\mathbf{p})$ \\
\hline CASO & 0,861 & 0,750 & $0,131(0,008)$ \\
CONTROL & 0,914 & 0,722 & $0,215(0,000)$ \\
Total & 0,926 & 0,690 & $<0.001$ \\
\hline
\end{tabular}

Con respecto al microsatélite FH2202 se detectaron 22 alelos en el total de la muestra, diecisiete en el grupo control y dieciséis en el grupo caso (Tabla 3.5). Como en el 
caso anterior muchos de los alelos solo se detectaron en uno de los grupos con baja frecuencia. Las frecuencias alélicas de este marcador variaron entre 0,02 y 0,24. Esto resultó en valores de $h_{e}$ de 0,904 y 0,922 y de $h_{o}$ de 0,680 y 0,700 en el grupo caso y en el grupo control, respectivamente (Tablas 3.6). Como en el caso anterior, el equilibrio HWE evidenció desviaciones significativas tanto en los dos grupos como en la población total (Tabla 3.6). En los tres casos los desvíos se debieron a un aumento significativo de individuos homocigotas. Además, no se observó un aumento significativo de homocigosis en el grupo caso con respecto al grupo control $(p<0,05)$.

Tabla 3.5. Frecuencias alélicas del microsatélite FH2202 (tetranucleótido) estimadas en los grupos caso y control.

\begin{tabular}{ccc}
\hline FH2202 (alelos) & CASO & CONTROL \\
\hline 377 & 0,02 & 0 \\
381 & 0 & 0,02 \\
385 & 0 & 0,02 \\
393 & 0,02 & 0,04 \\
397 & 0,05 & 0,04 \\
401 & 0,13 & 0,14 \\
405 & 0,02 & 0,08 \\
409 & 0,02 & 0 \\
413 & 0,13 & 0,08 \\
417 & 0,02 & 0 \\
421 & 0,05 & 0 \\
425 & 0,04 & 0,02 \\
429 & 0,24 & 0,24 \\
433 & 0,17 & 0,1 \\
437 & 0,04 & 0 \\
441 & 0,02 & 0,04 \\
445 & 0,02 & 0,02 \\
449 & 0,02 & 0,02 \\
453 & 0 & 0,02 \\
457 & 0 & 0,06 \\
469 & 0 & 0,02 \\
477 & 0 & 0,04 \\
\hline
\end{tabular}


Tabla 3.6. Valores estimados de heterocigosidad esperada $\left(h_{e}\right)$ y observada $\left(h_{o}\right)$ para el microsatélite FH2202 detectados en los grupos caso y control y la población total.

\begin{tabular}{cccc}
\hline Grupo & $\mathbf{h}_{\mathbf{e}}$ & $\mathbf{h}_{\mathbf{0}}$ & $\mathbf{F}_{\text {IS }}$ (valor de $\left.\mathbf{p}\right)$ \\
\hline CASO & 0,904 & 0,680 & $0,252(0,000)$ \\
CONTROL & 0,922 & 0,700 & $0,240(0,000)$ \\
Total & 0,899 & 0,738 & 0,001 \\
\hline
\end{tabular}

En conclusión, los tres microsatélites tipificados mostraron niveles de diversidad genética suficiente (en los grupos caso y control) para llevar a cabo los subsiguientes estudios de asociación.

\subsubsection{Región Reguladora Proximal de las Genes DLA-DRB1, DLA-DQA1 y DLA- DQB1.}

El análisis por secuenciación directa del $\mathrm{ADN}$ de la región reguladora proximal de los tres genes DLA de clase II puso en evidencia: dos SNPs del gen DLA-DRB1 (uno en el promotor y otro en el exón 1), dos SNPs en el gen DLA-DQA1 (uno en el promotor y otro en el exón 1) y seis SNPs en el gen DLA-DQB1 (cinco en el promotor y uno en el exón 1). Además, se detectó un INDEL en el promotor del gen DLA-DQB1 (Tabla 3.7, Figura 3.1ac). La mutación A/G (no sinónima) en la posición 46 del exón 1 del gen DLA-DQB1 específica del lobo no se detectó en la muestra analizada. 
Tabla 3.7. Características de los polimorfismos detectados en la región promotora/exon 1 de los genes de clase II DLA-DRB1, DLA-DQA1 y DLA-DQB1.

\begin{tabular}{|c|c|c|c|c|}
\hline Gen & Polimorfismo & Variación & $\begin{array}{c}\text { Promotor/ Exon } 1 \\
\text { (posición) }\end{array}$ & $\begin{array}{c}\text { Ubicación en el } \\
\text { genoma }\end{array}$ \\
\hline \multirow{2}{*}{$\begin{array}{l}\text { DLA- } \\
\text { DRB1 }\end{array}$} & DRB1*-128[C/T] & $\mathrm{C} / \mathrm{T}$ & -128 & CFA12:2151317 \\
\hline & $\mathrm{DRB} 1 * 69[\mathrm{C} / \mathrm{T}]$ & $\mathrm{C} / \mathrm{T}$ & 69 & CFA12:2151514 \\
\hline \multirow{2}{*}{$\begin{array}{l}\text { DLA- } \\
\text { DQA1 }\end{array}$} & DQA1*-85 [A/T] & $\mathrm{A} / \mathrm{T}$ & -85 & CFA12: 2221102 \\
\hline & DQA1*38 [C/T] & $\mathrm{C} / \mathrm{T}$ & 38 & CFA12: 2221225 \\
\hline \multirow{9}{*}{$\begin{array}{l}\text { DLA- } \\
\text { DQB1 }\end{array}$} & DQB1*-272 [indel] & TAAC/- & -272 & CFA12: 2244333 \\
\hline & DQB1*-256 [G/T] & $\mathrm{G} / \mathrm{T}$ & -256 & CFA12: 2244346 \\
\hline & DQB1*-170 [G/A] & $\mathrm{G} / \mathrm{A}$ & -170 & CFA12 : 2244432 \\
\hline & DQB1*-154 [C/T] & $\mathrm{C} / \mathrm{T}$ & -154 & CFA12 : 2244448 \\
\hline & DQB1*-105 [A/T] & $\mathrm{A} / \mathrm{T}$ & -105 & CFA12: 2244497 \\
\hline & DQB1-87 [C/T] & $\mathrm{C} / \mathrm{T}$ & -87 & CFA12: 2244515 \\
\hline & $\mathrm{DQB} 1{ }^{*}-71[\mathrm{C} / \mathrm{T}]$ & $\mathrm{C} / \mathrm{T}$ & -71 & CFA12: 2244531 \\
\hline & $\mathrm{DQB} 1 * 46[\mathrm{G} / \mathrm{A}]$ & $\mathrm{G} / \mathrm{A}$ & 46 & CFA12: 2244646 \\
\hline & DQB $1 * 71[\text { indel }]^{1}$ & INDEL & 71 & CFA12: 2244671 \\
\hline
\end{tabular}

' no analizado 
Figura 3.1. Alineamiento de la secuencias de las variantes alélicas de las regiones reguladoras proximales de los genes DLA de clase II. Se marcaron sus correspondientes sitios polimórficos y cajas reguladoras $(\mathrm{S}, \mathrm{X} 1, \mathrm{X} 2, \mathrm{Y}$ y T).

a) Gen DLA-DRB1

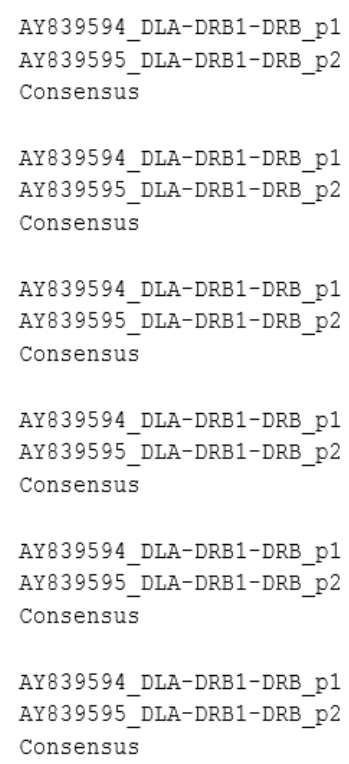

b) Gen DLA-DQA1

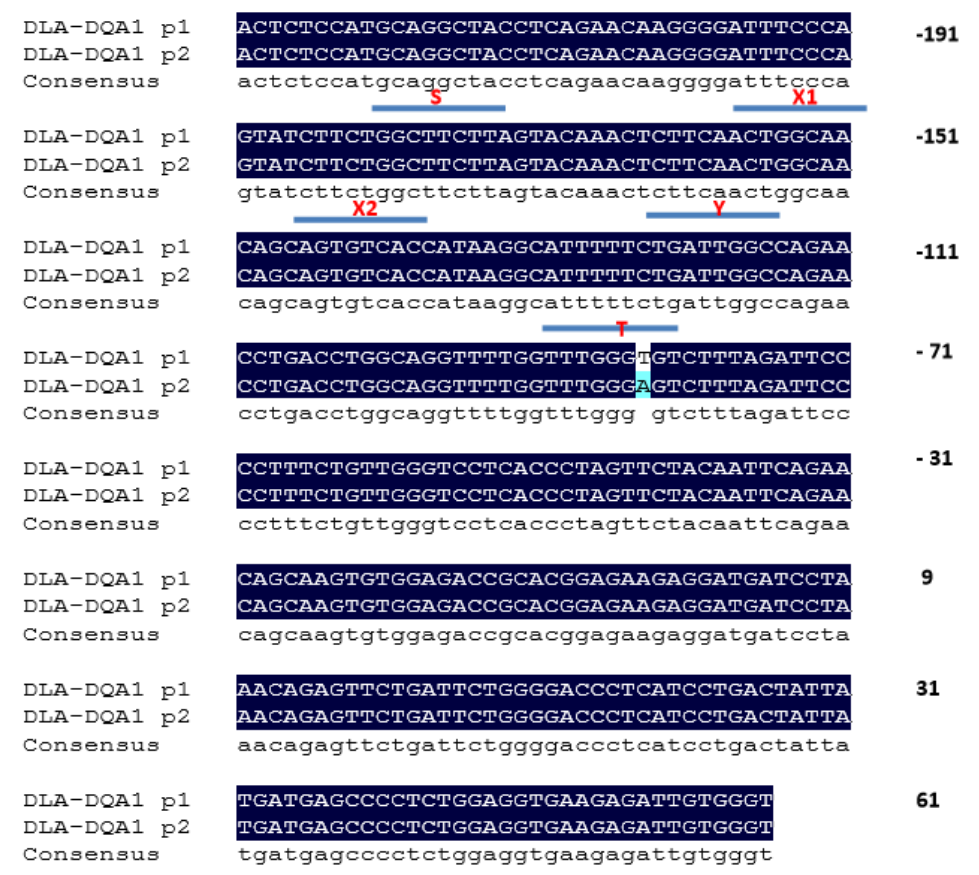


c) GenDLA-DQB1

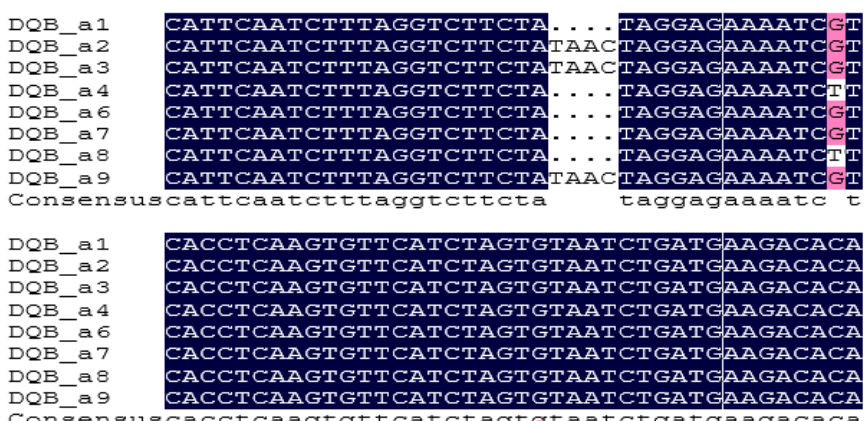

Consensuscacctcaagtgttcatctagtgुtaatctgatgaagacaca

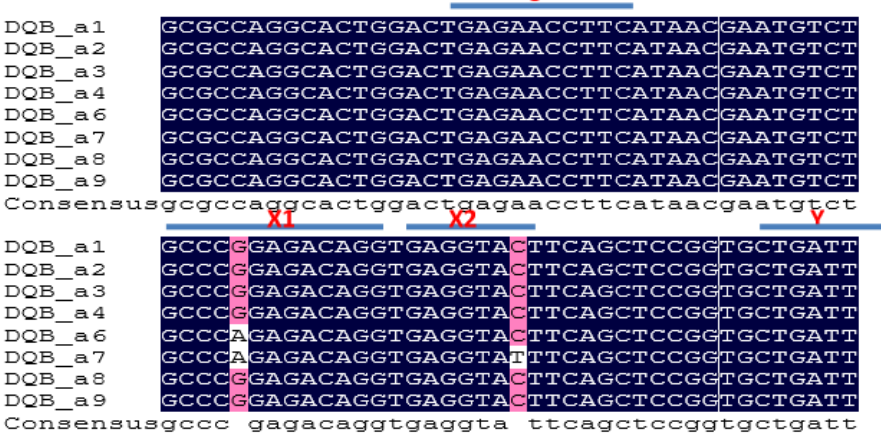

DQB_a

GGTTCCCTCCTAGGAACTCTCCAATCCTACTATGGATG

DQB_a2 GGTTCCCTCCCTAGGAACTCTCCAATCCTACTATGGATG

DQB_a3 GGTTCCCTCCCTAGGAACTCTCCAATCCTACTATGGATG

DQB_a 4 GGTTCCCTCCCTAGGAACTCTCCAATCCTACTATGGATG

DQB a 7 GGTTCCCTCCCTAGGAACTCTCCAATCCTACTATGGATG

DQB a 8 GGTTCCCTCCCTAGGAACTCTCCAATCCTACTATGGATG

DQB_ag GGTTCCCTCCCTAGGAACTCTCCAATCCTACTATGGATGG

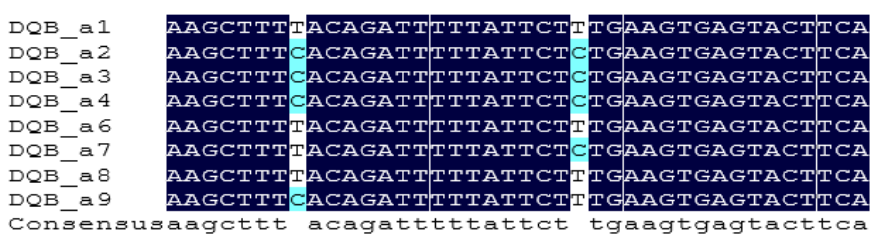

consensusaagcttt acagattttattct tgaagtgagtacttca

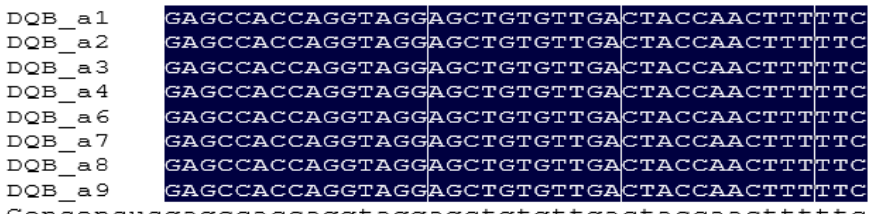

Consensusgagccaccaggtaggagctgtgttgactaccaactttttc 


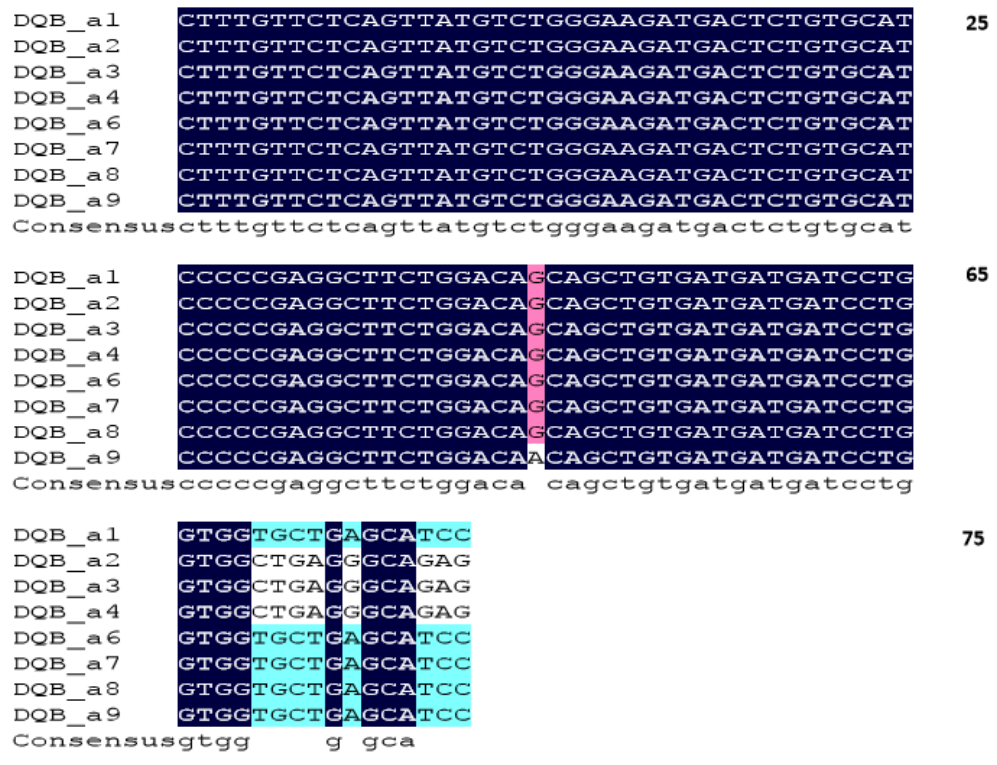

Como se mencionó anteriormente, para el gen DLA-DRB1 se detectaron dos polimorfismos (SNPs), el primero está ubicado en el promotor, denominado DRB1*-128 $[\mathrm{C} / \mathrm{T}]$ y otro está ubicado en el exón 1 y se denomina DRB1*69 [C/T]. Para cada uno de ellos se calculó la frecuencia génica, la heterocigocidad obsevada y esperada y el equilibrio de Hardy-Weinberg en la población total y en los grupos caso y control. Estos análisis mostraron que ambos polimorfismos presentaban frecuencias alélicas apreciables para sus dos alelos, resultando en $h_{E} y h_{0}$ cercanas al 0,5 (Tabla 3.8 y 3.9). Cabe destacar que ambos SNPs presentaban las mismas frecuencias alélicas, lo que estaría indicando un ligamiento completo entre ambos. Este punto se discute en más detalle en la sección de análisis de ligamiento. El equilibrio HWE mostró que los dos polimorfismos se ajustaban a las proporciones teóricas esperadas (Tabla 3.8 y 3.9).

En el caso del gen DLA-DQA1, se analizaron dos polimorfismos, uno ubicado dentro del promotor, denominado DQA1*-85 [A/T], y el otro ubicado en el exón 1, denominado DQA1*38 [C/T]. Ambos SNPs mostraron una variabilidad muy baja, siendo la frecuencia alélica de la variante T del SNP DQA1*-85 [A/T], resultó ser de 0,98 en la población total, mientras que la variante $\mathrm{C}$ del SNP DQA1*38 [C/T] se encontró fijada en la población de ovejeros alemanes estudiada. Esto resultó en valores de variabilidad genética cercana a cero, presentando el primer polimorfismo una $\mathrm{h}_{\mathrm{o}} \mathrm{y}$ una $\mathrm{h}_{\mathrm{e}}$, en los grupos caso y control de 
0,055 y 0,066, respectivamente. Para el segundo polimorfismo, tanto la $h_{o}$ como la $h_{e}$, presentaron valores de 0 (ver Tabla 3.8 y 3.9).

Se analizaron siete sitios polimórficos en el gen DLA-DQB1, seis dentro del promotor y uno dentro del exón 1. Tres de ellos se encontraron fijados: la variante $\mathrm{G}$ del SNP DQB1*-256 [G/T], la variante A del SNP DQB1*-105 [A/T] y la variante G del SNP DQB1*46 [G/A]. En el caso del INDEL DQB1*-272 [TAAC/-], la variante delecionada tuvo una frecuencia de 0,93. En el resto de los casos se obtuvieron frecuencias más apreciables. Se evaluaron las $h_{o} \mathrm{y}_{\mathrm{e}}$, tanto en la población total como en los grupos caso y control, en todos los casos no se observaron diferencias significativas con las proporciones teóricas esperadas. (Tabla 3.8 y 3.9).

Tabla 3.8. Frecuencias alélicas, heterocigosidad obsevada $\left(h_{0}\right)$ y esperada $\left(h_{e}\right)$, equilibrio de Hardy-Weinberg (HWE) calculada para cada polimorfismo detectado en los promotores de los genes DLA-DRB1, DLA-DQA1 y DLA-DQB1 en el total de la muestra. ND (no determinado).

\begin{tabular}{|c|c|c|c|c|c|}
\hline Polimorfismo & \multicolumn{2}{|c|}{$\begin{array}{c}\text { Frecuencias } \\
\text { alélicas }\end{array}$} & $\mathbf{h}_{\mathbf{0}}$ & $\mathbf{h}_{\mathbf{e}}$ & $\begin{array}{c}\text { HWE } \\
\text { F IS }_{\text {IS }}\end{array}$ \\
\hline $\mathrm{DRB}^{*}{ }_{-128}[\mathrm{C} / \mathrm{T}]$ & 0,63 & 0,37 & 0,542 & 0,474 & $0,16-0,65$ \\
\hline $\mathrm{DRB} 1 * 69[\mathrm{C} / \mathrm{T}]$ & 0,63 & 0,37 & 0,542 & 0,474 & $0,16-0,65$ \\
\hline DQA $1 *-85[\mathrm{~A} / \mathrm{T}]$ & 0,02 & 0,98 & 0,033 & 0,033 & $-0.02-1,00$ \\
\hline DQA $1 * 38[\mathrm{C} / \mathrm{T}]$ & 1 & 0 & 0 & 0 & ND \\
\hline DQB1*-272 [TAAC/-] & 0,07 & 0,93 & 0 & 0,135 & $1,00-0,003$ \\
\hline DQB1*-256 [G/T] & 1 & 0 & 0 & 0 & ND \\
\hline $\mathrm{DQB}^{*}{ }_{-170}[\mathrm{G} / \mathrm{A}]$ & 0,43 & 0,57 & 0,61 & 0,495 & $-0,23-0,39$ \\
\hline DQB1*-154 [C/T] & 0,59 & 0,41 & 0,535 & 0,488 & $-0,08-1,00$ \\
\hline DQB1*-105 [A/T] & 1 & 0 & 0 & 0 & ND \\
\hline DQB1-87 [C/T] & 0,36 & 0,64 & 0,535 & 0,466 & $-0,10-1$ \\
\hline $\mathrm{DQB} 1 *_{-7} 1[\mathrm{C} / \mathrm{T}]$ & 0,72 & 0,28 & 0,302 & 0,396 & $0,07-1$ \\
\hline $\mathrm{DQB} 1 * 46[\mathrm{G} / \mathrm{A}]$ & 1 & 0 & 0 & 0 & ND \\
\hline
\end{tabular}


Tabla 3.9. Heterocigosidad obsevada $\left(h_{0}\right)$ y esperada $\left(h_{e}\right)$, equilibrio de Hardy-Weinberg (HWE) calculada para cada polimorfismo detectado en los promotores de los genes DLADRB1, DLA-DQA1 y DLA-DQB1en los grupos caso y control. ND (no determinado).

\begin{tabular}{lcccccc}
\hline Polimorfismo & Grupo & \multicolumn{2}{c}{$\begin{array}{c}\text { Frecuencias } \\
\text { alélicas }\end{array}$} & $\mathbf{h}_{\mathbf{o}}$ & $\mathbf{h}_{\mathbf{e}}$ & HWE (FIS - p) \\
\hline DRB1*-128 [C/T] & CASO & 0,73 & 0,27 & 0,4 & 0,4 & $0,04(1)$ \\
& CONTROL & 0.6 & 0,4 & 0,64 & 0,49 & $-0,29(0,2)$ \\
DRB1*69 [C/T] & CASO & 0,69 & 0,31 & 0,36 & 0,43 & $0,16(0,63)$ \\
& CONTROL & 0,56 & 0,44 & 0,66 & 0,5 & $-0,33(0,33)$ \\
DQA1*-85 [A/T] & CASO & 0 & 1 & 0,055 & 0,055 & ND \\
& CONTROL & 0,06 & 0,94 & 0,066 & 0,066 & ND \\
DQA1*38 [C/T] & CASO & 1 & 0 & 0 & 0 & ND \\
& CONTROL & 1 & 0 & 0 & 0 & ND \\
DQB1*-272 [TAAC/-] & CASO & 0,1 & 0,9 & 0 & 0,13 & $1(0,03)$ \\
& CONTROL & 0,18 & 0,82 & 0 & 0,3 & $1(0,007)$ \\
DQB1*-256 [G/T] & CASO & 1 & 0 & 0,055 & 0,055 & ND \\
& CONTROL & 1 & 0 & 0 & 0 & ND \\
DQB1*-170 [G/A] & CASO & 0,38 & 0,66 & 0,58 & 0,47 & $-0,23(0,39)$ \\
& CONTROL & 0,52 & 0,48 & 0,6 & 0,51 & $-0,2(0,42)$ \\
DQB1*-154 [C/T] & CASO & 0,45 & 0,55 & 0,62 & 0,5 & $-0,23(0,43)$ \\
& CONTROL & 0,72 & 0,28 & 0,39 & 0,42 & $0,06(1)$ \\
DQB1*-105 [A/T] & CASO & 0,98 & 0,02 & 0,04 & 0,04 & ND \\
& CONTROL & 1 & 0 & 0 & 0 & ND \\
DQB1-87 [C/T] & CASO & 0,28 & 0,72 & 0,5 & 0,42 & $-0,19(0,63)$ \\
& CONTROL & 0,44 & 0,56 & 0,52 & 0,5 & $-0,04(1)$ \\
DQB1*-71[C/T] & CASO & 0,8 & 0,2 & 0,3 & 0,36 & $0,15(0,58)$ \\
& CONTROL & 0,68 & 0,32 & 0,3 & 0,44 & $0,33(0,16)$ \\
DQB1*46 [G/A] & CASO & 1 & 0 & 0 & 0 & ND \\
& CONTROL & 1 & 0 & 0 & 0 & ND \\
\hline
\end{tabular}

Debido a que los polimorfismos tipificados para los tres genes de clase II se encuentran cercanos en el genoma, se llevó a cabo el análisis del desequilibrio de ligamiento (LD) utilizando los algoritmos "Four Gamete Rule" y "Solid spine pf LD" implementados en el software Haploview. Este análisis permitió identificar dos bloques de ligamiento con un $r^{2} \leq 45$ (Figura 3.2). El primer bloque incluye dos haplotipos del gen DLA-DRB1 (CC y TT), presentando ambas combinaciones frecuencias apreciables en la 
población total (Figura 3.2b). Como se mencionó anteriormente estos SNPs evidenciaron un valor de $\mathrm{r}^{2}$ de 1 por presentar un ligamiento completo. Por lo que desde el punto de vista práctico, solo haría falta tipificar uno solo de estos polimorfismos para estudios de asociación o de variabilidad genética. El segundo bloque incluye 5 haplotipos del gen DLA-DQB1, tres de ellos presentaron frecuencias superiores al 10\%, mientras que los dos restantes resultaron ser combinaciones raras en la población estudiada (Figura 3.2). Las frecuencias haplotípicas de los dos bloques de ligamiento en los grupos caso y control se resumen en la tabla 3.10, evidenciando que los 7 haplotipos identificados se detectaron en ambos grupos pero con frecuencias diferentes en alguno de ellos. Cabe mencionar que el gen DLA-DQA1 no se incluyó en el análisis de desequilibrio de ligamiento debido a su bajo nivel de variabilidad genética en la raza de ovejeros alemanes. La construcción de los haplotipos permitió la realización de los estudios de asociación con la QSC tanto a nivel alélico como haplotípico. 
Figura 3.2. Haplotipos y desequilibrio de ligamiento (LD) en las regiones reguladoras proximales de los genes DLA-DRB1, DLA-DQA1 y DLA-DQB1. a) Bloques haplotípicos 1 y 2. b) Se obtuvo el LD $\left(r^{2}\right)$ utilizando el software HAPLOVIEW 3.31 (Barrett y col., 2005). Las líneas gruesas marcan los dos bloques identificados.

a)

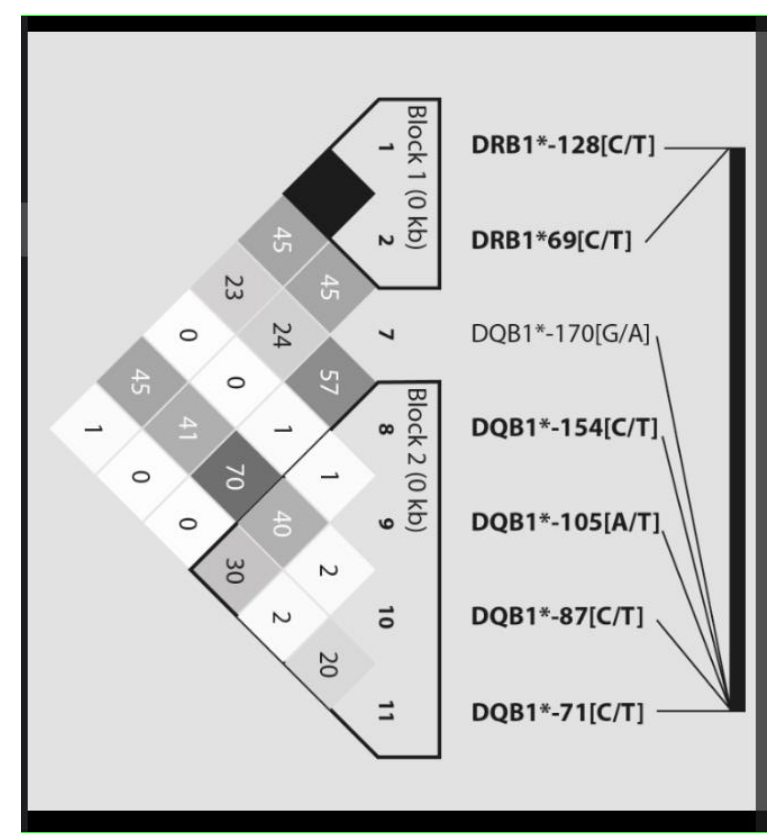

b)

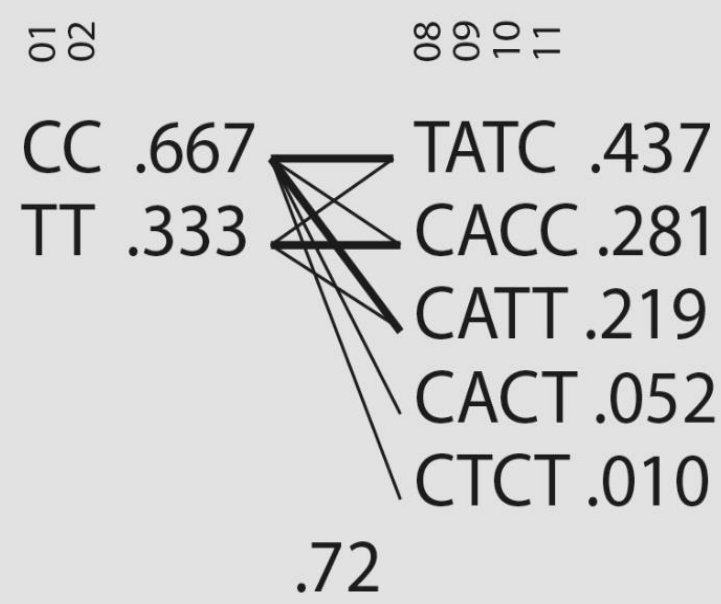


Tabla 3.10. Frecuencias haplotípicas de las regiones reguladoras proximales de los genes DLA-DRB1 y DLA-DQB1 en los grupos caso y control.

\section{Haplotipo}

\begin{tabular}{ccc} 
& Caso & Control \\
\hline URR-DRB1*CC & 0,36 & 0,26 \\
URR-DRB1*TT & 0,2 & 0,18 \\
URR-DQB*TATC & 0,54 & 0,28 \\
URR-DQB*CACC & 0,23 & 0,47 \\
URR-DQB*CATT & 0,17 & 0,24 \\
URR-DQB*CACT & 0,039 & 0 \\
URR-DQB*CTCT & 0,02 & 0 \\
\hline
\end{tabular}

En conclusión, las regiones promotoras de dos de los tres genes de clase II tipificados mostraron niveles suficientes de diversidad genética en los grupos caso y control para poder llevar a cabo los subsiguientes estudios de asociación tanto a nivel alélico como haplotípico, siendo la excepción el gen DLA-DQA1 el cual no presentó variabilidad genética.

\subsubsection{Región Presentadora de Antígenos (exón 2) de las Genes DLA-DRB1, DLA- DQA1 y DLA-DQB1}

Debido a su rol central en el reconocimiento y presentación de antígenos, el segundo exón o ARS (Antigen recognition site) de los genes de clase II DRB1, DQA1 y DQB1 presenta niveles excepcionales de variabilidad genética, siendo polimórficas gran parte de las posiciones nucleotídicas. Es por esta razón que la mayor dificultad para la identificación de los alelos en los individuos heterocigotas es la determinación de las fases de ligamiento entre los numerosos sitios polimórficos. Con el fin de solucionar este problema, en el presente estudio el análisis de las secuencias del exón 2 de los tres genes de DLA de clase II obtenidas se realizó mediante un software desarrollado en colaboración con el equipo de bioinformática del IGEVET. Este software se programó en los lenguajes Python (https://www.python.org/) y R (https://www.r-project.org/). En una primera etapa se desarrolló un script en Python, utilizando la biblioteca BioPython 
(http://biopython.org/wiki/Biopython). Este script lee las secuencias a partir del cromatograma en formato FASTA, permitiendo la notación $[\mathrm{A} / \mathrm{C}]$ para las posiciones polimórficas y las de todos los alelos reportados extraídos de la base de datos IPD-MHC (https://www.ebi.ac.uk/ipd/mhc/; ANEXO 12) en el formato de texto original. A partir de las secuencias de referencia que figuran en dicha base de datos, se generan todas las combinaciones posibles tomadas de a dos. Ese resultado se convierte a la nomenclatura IUPAC (Tabla 3.12), al igual que la secuencia problema leída a partir del cromatograma problema. Luego se alinea con cada una de las combinaciones de haplotipos, calculando coincidencias y diferencias, reportando en un archivo las secuencias, el alineamiento y las diferencias, finalmente ordenado de mayor a menor por cantidad de coincidencias. Además, se utilizó también una librería de R/Bioconductor llamada sangerseqR, que permite la lectura automática de los cromatogramas en formato .abd, generando un archivo con las secuencias primaria y secundaria, y el cromatograma correspondiente con las secuencias interpretadas. El uso de este paquete de R permitió detectar algunos errores en el algoritmo original de sangerseqR, que producen algunas lecturas erróneas en ciertas situaciones. Por lo tanto, se reportaron los errores encontrados y se resolvió el problema hallado en la librería. Por otra parte, se desarrolló en $\mathrm{R}$ una función para calcular la reversa complementaria del cromatograma, necesario para comparar las lecturas forward y reverse. Esta función no estaba disponible en el paquete de original de Bioconductor mencionado, pero sí en otros software, como por ejemplo el UGENE. La función será enviada al proyecto sangerseqR una vez que sea adaptada a los estándares de estilo de dicha biblioteca. Cabe destacar que para validar y corroborar los resultados del algoritmo desarrollado para este trabajo, la edición de las secuencias se realizó paralelamente en forma manual. Si bien en esta instancia el desarrollo es una prueba de concepto, se han logrado reunir todos los módulos necesarios para resolver el problema propuesto y falta aún desarrollar el script como una aplicación con interfase gráfica, que facilite la edición de errores de lectura y recalcule los alineamientos y comparaciones de forma amigable. En la figura 3.3 se describe el flujo de trabajo implementado en el software desarrollado para el análisis de las secuencias del exón 2 de los genes de clase II. 
Tabla 3.11. Código de ambigüedad nucleotídica (IUPAC, International Union of Pure and Applied Chemistry).

\begin{tabular}{ccc}
\hline CÓDIGO & Representa & Complemento \\
\hline A & ADENINA & T \\
G & GUANINA & C \\
C & CITOSINA & G \\
T & TIMINA & A \\
Y & Co T & R \\
R & A o G & Y \\
W & A o T & W \\
S & C o G & S \\
K & To G & K \\
M & Co A & H \\
D & A, G, T (no C) & B \\
V & A, C, G (no T) & D \\
H & A, C, T (no G) & V \\
B & C, G, T (no A) & X/N \\
X/N & Cualquier base & - \\
- & GAP &
\end{tabular}


Figura 3.3. Flujo de trabajo del software diseñado para asignar los genotipos de los exones 2 de los genes de clase II. 1) Base de datos IPD-MHC donde se encuentran reportados los alelo/haplotipos del exón 2. 2) Conversión a nomenclatura IUPAC. 3) Secuencia teórica. 4) Secuencia problema en formato .abd. 5) Cromatograma de la secuencia problema. 6) Secuencia problema en formato FASTA con nomenclatura original. 7) Secuencia problema en formato FASTA con nomenclatura IUPAC. 8) Ranking de comparaciones tomadas de a pares ordenado los posibles genotipos de mayor a menor número de coincidencias.9) Identificación del genotipo del individuo problema.

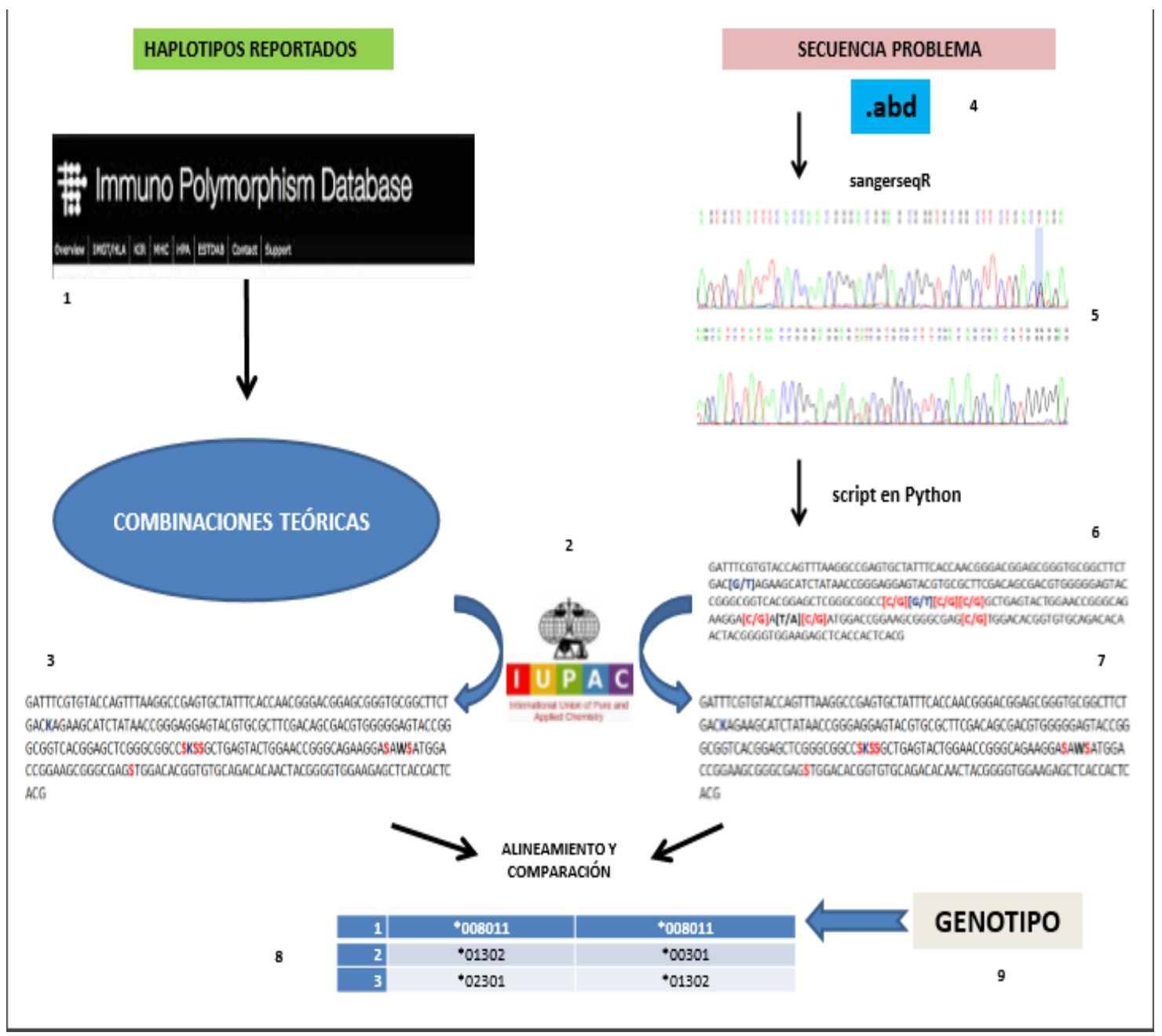

Para el análisis de los exones 2 (región presentadora de antígenos) de los genes DLADRB1, y -DQA1 se tipificaron los 73 perros clasificados en grupo caso $(\mathrm{N}=43)$ y grupo control $(\mathrm{N}=30)$ según los criterios antes mencionados. 
Para el exón 2 del gen DLA-DRB1 se detectaron 15 alelos/haplotipos en el total de la muestra de los 52 variantes reportadas actualmente para este marcador genético (ANEXO 12), 9 en el grupo control y 10 en el grupo caso (Tabla 3.12). Las frecuencias alélicas de este marcador variaron entre 0,01 y 0,45 en la población total. Esto resultó en valores de $\mathrm{h}_{\mathrm{e}}$ de $0,86 \mathrm{y} \mathrm{h}_{\mathrm{o}}$ de 0,69 en la población total. La diversidad genética dentro de los grupos caso y control fue de 0,848 y 0,88 para la $h_{e}$ y de 0,667 y 0,733 para la $h_{0}$, respectivamente (Tabla 3.13). El equilibrio HWE mostró que en ambos grupos (estimado a partir del índice $\mathrm{F}_{\text {IS }}$ ) y en la población total (estimado mediante el método exacto de Fisher) las frecuencias alélicas no se ajustaban a las proporciones teóricas esperadas (Tabla 3.13). Estos desvíos se debieron principalmente a un aumento significativo de individuos homocigotas.

Tabla 3.12. Frecuencias alélicas del exón 2 del gen DLA-DRB1 estimadas en los grupos caso, control y en la población total.

\begin{tabular}{cccc}
\hline ALELO & CASO & CONTROL & TOTAL \\
\hline$* \mathbf{0 0 1 0 1}$ & 0,11 & 0,03 & 0,08 \\
$* \mathbf{0 0 2 0 2}$ & 0 & 0,03 & 0,01 \\
$* \mathbf{0 1 1 0 1}$ & 0,48 & 0,4 & 0,45 \\
$* \mathbf{0 1 2 0 1}$ & 0 & 0,03 & 0,01 \\
$* \mathbf{0 1 5 0 1}$ & 0,23 & 0,18 & 0,22 \\
$* \mathbf{0 1 5 0 2}$ & 0 & 0,18 & 0,08 \\
$* \mathbf{0 1 5 0 3}$ & 0 & 0,03 & 0,01 \\
$* \mathbf{0 1 6 0 1}$ & 0,02 & 0 & 0,01 \\
$* \mathbf{0 1 7 0 1}$ & 0 & 0,06 & 0,04 \\
$* \mathbf{0 2 0 0 1}$ & 0,08 & 0 & 0,04 \\
$* \mathbf{0 2 1 0 1}$ & 0,02 & 0 & 0,01 \\
$* \mathbf{0 3 0 0 1}$ & 0 & 0,03 & 0,01 \\
$* \mathbf{0 3 5 0 1}$ & 0 & 0,03 & 0,01 \\
$* \mathbf{0 3 7 0 1}$ & 0,02 & 0 & 0,01 \\
$* \mathbf{0 3 9 0 1}$ & 0,02 & 0 & 0,01 \\
\hline
\end{tabular}

Tabla 3.13. Valores estimados de heterocigosidad esperada $\left(h_{e}\right)$ y observada $\left(h_{0}\right)$ para el exón 2 del gen DLA-DRB1 detectados en los grupos caso y control y la población total.

\begin{tabular}{cccc}
\hline Grupo & $\mathbf{h}_{\mathbf{e}}$ & $\mathbf{h}_{\mathbf{0}}$ & $\mathbf{F}_{\text {IS }}($ valor de $\mathbf{p})$ \\
\hline CASO & 0,848 & 0,667 & $0,218(0,015)$ \\
CONTROL & 0,88 & 0,733 & $0,172(<0,00001)$ \\
Total & 0,86 & 0,69 & High sign \\
\hline
\end{tabular}


En cuanto al exón 2 del gen DLA-DQA1 se detectaron 7 alelos en el total de la muestra de las 16 variantes reportadas para este marcador genético en la base de datos pública IPD-MHC (ANEXO 12). En los grupos caso y control se identificaron 7 y 4 alelos, respectivamente (Tabla 3.14). Las frecuencias alélicas de este marcador variaron entre 0,01 y 0,41 en la población total. Esto resultó en valores de $h_{e}$ de 0,886 y 0,824 y de $h_{o}$ de 0,572 y 0,588 en el grupo caso y en el grupo control, respectivamente (Tablas 3.15). El equilibrio HWE mostró que en los dos grupos y en la población total las frecuencias alélicas no se ajustaban a las proporciones teóricas esperadas bajo el HWE (Tabla 3.15). En los tres casos los desvíos se debieron a un aumento significativo de individuos homocigotas.

Tabla 3.14. Frecuencias alélicas del exón 2 del gen DLA-DQA1 estimadas en los grupos caso, control y en la población total.

\begin{tabular}{cccc}
\hline ALELO & CASO & CONTROL & TOTAL \\
\hline$* \mathbf{0 0 1 0 1}$ & 0,05 & 0,28 & 0,17 \\
$* \mathbf{0 0 2 0 1}$ & 0,46 & 0,36 & 0,41 \\
$* \mathbf{0 0 4 0 1}$ & 0,11 & 0,08 & 0,09 \\
$* \mathbf{0 0 6 0 1}$ & 0,25 & 0,28 & 0,26 \\
$* \mathbf{0 1 4 0 1}$ & 0,05 & 0 & 0,03 \\
$* \mathbf{0 1 5 0 1}$ & 0,05 & 0 & 0,03 \\
$* \mathbf{0 5 0 1 1}$ & 0,03 & 0 & 0,01 \\
\hline
\end{tabular}

Tabla 3.15. Valores estimados de heterocigosidad esperada $\left(h_{e}\right)$ y observada $\left(h_{o}\right)$ para el exón 2 del gen DLA-DQA1 detectados en los grupos caso y control y la población total.

\begin{tabular}{cccc}
\hline Grupo & $\mathbf{h}_{\mathbf{e}}$ & $\mathbf{h}_{\mathbf{0}}$ & $\mathbf{F}_{\text {IS }}($ valor de p) \\
\hline CASO & 0,886 & 0,572 & $0,363(0,00328)$ \\
CONTROL & 0,824 & 0,588 & $0,29(0,0041)$ \\
Total & 0,85 & 0,58 & 0,00013 \\
\hline
\end{tabular}

Con respecto al exón 2 del gen DLA-DQB1, se detectaron 13 alelos en el total de la muestra de los 36 variantes reportadas en las bases de datos ( ANEXO 12), 9 en el grupo caso y 11 en el grupo control (Tabla 3.16). Algunos alelos solo se detectaron en uno de los grupos o presentaron baja frecuencia. Las frecuencias alélicas de este marcador variaron entre 0,011 y 0,371. Esto resultó en valores de $h_{\mathrm{e}}$ de 0,75 y 0,844 y de $h_{\mathrm{o}}$ de 0,667 y 0,6 en el grupo caso y en el grupo control, respectivamente, mientras que la muestra total presentó 
valores de $h_{e}$ de 0,81 y de $h_{o}$ de 0,64 (Tablas 3.17). Como en los dos casos anteriores, el equilibrio HWE evidenció desviaciones significativas tanto en los dos grupos como en la población total (Tabla 3.17). En los tres casos los desvíos se debieron a un aumento significativo de individuos homocigotas, hecho que coincidió en los exones 2 de los tres genes de clase II evaluados.

Tabla 3.16. Frecuencias alélicas del exón 2 del gen DLA-DQB1 estimadas en los grupos caso, control y en la población total.

\begin{tabular}{cccc}
\hline ALELO & CASO & CONTROL & TOTAL \\
\hline$* \mathbf{0 0 2 0 1}$ & 0,12 & 0,28 & 0,2 \\
$* \mathbf{0 0 3 0 1}$ & 0,12 & 0,1 & 0,1 \\
$* \mathbf{0 0 8 0 1 1}$ & 0,09 & 0 & 0,05 \\
$* \mathbf{0 0 8 0 2}$ & 0,07 & 0,125 & 0,1 \\
$* \mathbf{0 1 3 0 1}$ & 0,02 & 0,025 & 0,02 \\
$* \mathbf{0 1 3 0 2}$ & 0,45 & 0,25 & 0,36 \\
$* \mathbf{0 1 3 0 3}$ & 0,02 & 0,025 & 0,02 \\
$* \mathbf{0 1 7 0 1}$ & 0 & 0,025 & 0,01 \\
$* \mathbf{0 2 1 0 1}$ & 0 & 0,025 & 0,01 \\
$* \mathbf{0 2 2 0 1}$ & 0 & 0,025 & 0,01 \\
$* \mathbf{0 2 3 0 1}$ & 0,09 & 0,1 & 0,1 \\
$* \mathbf{0 2 4 0 1}$ & 0 & 0,025 & 0,01 \\
$* \mathbf{0 3 2 0 1}$ & 0,02 & 0 & 0,01 \\
\hline
\end{tabular}

Tabla 3.17. Valores estimados de heterocigosidad esperada $\left(h_{e}\right)$ y observada $\left(h_{0}\right)$ para el exón 2 del gen DLA-DQB 1 detectados en los grupos caso y control y la población total.

\begin{tabular}{cccc}
\hline Grupo & $\mathbf{h}_{\mathbf{e}}$ & $\mathbf{h}_{\mathbf{0}}$ & F $_{\text {IS }}($ valor de $\mathbf{p})$ \\
\hline CASO & 0,75 & 0,667 & $0,11(0,0284)$ \\
CONTROL & 0,844 & 0,6 & $0,29(<0,00001)$ \\
Total & 0,81 & 0,64 & High sign \\
\hline
\end{tabular}

En los tres exones 2 analizados no se observó un aumento significativo de homocigosis en el grupo caso con respecto al grupo control $(p<0,05)$. En los tres exones 2 tipificados se observaron niveles elevados de diversidad genética, en los grupos caso y control, suficientes para poder llevar a cabo los subsiguientes estudios de asociación. 


\subsubsection{Análisis de los haplotipos de la región presentadora de antígenos}

Para determinar los haplotipos compuestos por las tres regiones presentadoras de antígenos de utilizó el análisis multilocus del software Pypop. Se encontraron en la muestra un total de 11 haplotipos, 9 en el grupo caso y 6 en el grupo control (Tabla 3.18) con una frecuencia haplotípica entre 0,1 y 0,43 en la población total.

Tabla 3.18. Haplotipos DRB1/DQA1/DQB1. Frecuencias haplotípicas en el grupo caso, control y población total.

\begin{tabular}{ccccc}
\hline Haplotipo & DRB1/DQA1/DQB1 & CASO & CONTROL & TOTAL \\
\hline $\mathbf{1}$ & $01101 / 00201 / 01302$ & 0,53 & 0,32 & 0,43 \\
$\mathbf{2}$ & $01501 / 00601 / 00301$ & 0,13 & 0,12 & 0,125 \\
$\mathbf{3}$ & $00101 / 00101 / 00201$ & 0,11 & 0,32 & 0,2 \\
$\mathbf{4}$ & $01501 / 00601 / 02301$ & 0,11 & 0,12 & 0,11 \\
$\mathbf{5}$ & $01501 / 00201 / 01302$ & 0,03 & 0 & 0,01 \\
$\mathbf{6}$ & $02001 / 01501 / 08011$ & 0,03 & 0 & 0,01 \\
$\mathbf{7}$ & $02001 / 00401 / 08011$ & 0,03 & 0 & 0,01 \\
$\mathbf{8}$ & $00101 / 01501 / 00802$ & 0,03 & 0 & 0,01 \\
$\mathbf{9}$ & $01601 / 00401 / 00802$ & 0,03 & 0 & 0,01 \\
$\mathbf{1 0}$ & $01501 / 00101 / 00201$ & 0 & 0,03 & 0,01 \\
$\mathbf{1 1}$ & $01501 / 00601 / 00802$ & 0 & 0,09 & 0,04 \\
\hline
\end{tabular}

\subsection{Análisis de asociación.}

\subsubsection{Microsatélites.}

Debido a que los microsatélites genotipados presentaron un alto número de alelos, muchos de los cuales se detectaron a muy baja frecuencia génica se utilizaron para hacer la asociación los alelos que estaban más representados en la población. Los resultados obtenidos mostraron una asociación significativa entre los alelos FH2054*172 (valor de p $=0,02$ ) y el FH2975*320 (valor de p = 0,005) y el desarrollo de la QSC. En el caso del alelo FH2054*172, solo se presentó en los animales enfermos en una frecuencia de 0,12 y presentó un $\mathrm{OR}=6,55$, con IC 95\%=0,8-251. El microsatélite $\mathrm{FH} 2975^{* 320}$ se presentó en una frecuencia significativamente mayor en el grupo caso $(0,47)$ que en grupo caso, con un valor de $\mathrm{OR}=3,27$ con IC $95 \%=1,42-9,44$. El microsatélite FH2202 no evidenció 
asociaciones significativas con QSC en la población de ovejeros animales en estudio (Tabla 3.19).

Tabla 3.19. Análisis de asociación entre el desarrollo de QSC y los alelos de los microsatélites FH2054, FH2975 y FH2202.OR (Odds ratio). IC (Intervalo de confianza). En negrita se marcaron los valores significativos.

\begin{tabular}{|c|c|c|c|c|c|}
\hline \multirow{5}{*}{ Alelo } & \multicolumn{2}{|c|}{ Frecuencia alélica } & \multirow{5}{*}{$\begin{array}{c}\text { Test } \\
\text { exacto de } \\
\text { Fisher } \\
\text { (valor de } \\
\text { p) }\end{array}$} & \multirow[t]{5}{*}{ OR } & \multirow[t]{5}{*}{$95 \%$ IC } \\
\hline & & & & & \\
\hline & Caso & Control & & & \\
\hline & & & & & \\
\hline & & & & & \\
\hline FH2054*148 & 0,06 & 0 & 0,14 & 3 & $0,37-133$ \\
\hline FH2054*152 & 0,4 & 0,38 & 1 & 0,99 & $0,5-2,24$ \\
\hline FH2054*156 & 0,06 & 0,12 & 0,3 & 0,38 & $0,14-1,68$ \\
\hline FH2054*164 & 0,15 & 0,14 & 1 & 1 & $0,33-3,56$ \\
\hline FH2054*168 & 0,2 & 0,36 & 0,09 & 0,42 & $0,2-1,05$ \\
\hline FH2054*172 & 0,12 & 0 & $\mathbf{0 , 0 2}$ & 6,55 & $0,8-251$ \\
\hline FH2975*300 & 0,02 & 0,11 & 0,09 & 0,12 & $0,03-1,33$ \\
\hline $\mathrm{FH} 2975 * 312$ & 0,02 & 0,11 & 0,09 & 0,12 & $0,03-1,33$ \\
\hline $\mathrm{FH} 2975 * 320$ & 0,47 & 0,18 & 0,005 & 3,27 & $1,42-9,44$ \\
\hline FH2975*324 & 0,02 & 0,11 & 0,09 & 0,12 & $0,03-1,33$ \\
\hline FH2975*348 & 0,17 & 0,05 & 0,09 & 2,45 & $0,75-13,4$ \\
\hline $\mathrm{FH} 2975 * 352$ & 0,05 & 0,16 & 0,01 & 0,24 & $0,08-1,24$ \\
\hline $\mathrm{FH} 2202 * 397$ & 0,05 & 0,04 & 1 & 0,82 & $0,22-6,22$ \\
\hline $\mathrm{FH} 2202 * 401$ & 0,14 & 0,125 & 1 & 0,94 & $0,36-3,3$ \\
\hline $\mathrm{FH} 2202 * 405$ & 0,017 & 0,08 & 0,17 & 0,15 & $0,04-1,7$ \\
\hline $\mathrm{FH} 2202 * 413$ & 0,14 & 0,083 & 0,54 & 1,38 & $0,5-5,6$ \\
\hline $\mathrm{FH} 2202 * 429$ & 0,24 & 0,23 & 1 & 0,95 & $0,43-2,58$ \\
\hline $\mathrm{FH} 2202 * 433$ & 0,17 & 0,1 & 0,4 & 1,48 & $0,56-5,2$ \\
\hline $\mathrm{FH} 2202 * 457$ & 0 & 0,06 & 0,08 & 0 & $0,005-2,2$ \\
\hline
\end{tabular}


Evaluando la hipótesis de que la homocigosis aumenta el riesgo a desarrollar QSC, se realizó el análisis de asociación entre la homocigosis de los tres microsatélites y la enfermedad. En ninguno de los casos de observaron diferencias significativas (Tabla 3.20).

Tabla 3.20. Análisis de asociación entre el desarrollo de QSC y la heterocigocidad observada $\left(h_{\mathrm{o}}\right)$ para los alelos de los microsatélites FH2054, FH2975 y FH 2202. OR (Odds Ratio). IC (Intervalo de confianza).

\begin{tabular}{lccccc}
\hline Microsatélite & \multicolumn{2}{c}{ Ho } & $\begin{array}{c}\text { Test exacto de Fisher } \\
\text { (valor de p) }\end{array}$ & OR & 95\% IC \\
& Caso & Control & & & \\
\hline FH2054 & 0,56 & 0,64 & 0,59 & 0,7 & $0,4-2,32$ \\
FH2975 & 0,78 & 0,65 & 0,37 & 1,93 & $0,59-6,51$ \\
FH2202 & 0,79 & 0,7 & 1,55 & 0,43 & $0,43-5,8$ \\
\hline
\end{tabular}

\subsubsection{Región Reguladora Proximal de los genes DLA-DRB1, DLA-DQA1 y DLA- DQB1}

La asociación entre la QSC y los alelos/haplotipos de las regiones promotoras de los genes los tres genes de clase II del DLA se evaluó utilizando un clásico estudio de casocontrol. La frecuencia de cada alelo dentro de cada grupo, caso y control, se comparó utilizando el Test exacto de Fisher y Odds ratio (OR),

Para el gen DLA-DRB 1 se estimó la frecuencia de cada alelo dentro de cada grupo y se las comparó utilizando el Test exacto de Fisher y Odds ratio (OR), con un intervalo de confianza de 95\% (ver tabla 3.21). En ninguno de los dos se apreciaron diferencias significativas entre los grupos.

En el caso del gen DLA-DQA1, los alelos se encontraron casi fijados en el SNP DQA1*85 [A/T] y fijado en el DQA1* 38 [C/T], el alelo $\mathrm{T}$ y el alelo $\mathrm{C}$ respectivamente. Debido a esto no se pudo asociar este gen al desarrollo de QSC (Tabla 3.21)

En el gen DLA-DQB1 se observaron diferencias significativas en las frecuencias del SNP DQB1*-154 [C/T], con un valor de p de 0,016 y un OR de 3, donde la variante $\mathrm{T}$ aumentaría el riesgo a desarrollar QSC (Tabla 3.21). Este resultado se confirmó cuando se realizó la asociación entre los haplotipos de la región promotora y QSC. El haplotipo URRDQB*TATC, el único que contiene la variante T del SNP DQB1*-154 [C/T], estuvo 
significativamente asociado con la QSC $(\mathrm{p}=\mathbf{0 , 0 0 6})$, incrementando tres veces el riego de desarrollar la enfermedad $(\mathrm{OR}=3,08 \%, \mathrm{IC}=1,43-8)($ Tabla 3.22)

Tabla 3.21. Frecuencias alélicas estimadas en los grupos caso y control para los promotores de los genes DLA-DRB1, DLA-DQA1 and DLA-DQB1. La frecuencia de cada alelo dentro de cada grupo se comparó utilizando el Test exacto de Fisher y Odds ratio (OR). IC (Intervalo de confianza). ND (no determinado).

\begin{tabular}{|c|c|c|c|c|c|}
\hline \multirow[t]{2}{*}{ Polimorfismo } & \multicolumn{2}{|c|}{ Frecuencia génica } & \multirow{2}{*}{$\begin{array}{c}\text { Test exacto } \\
\text { de Fisher } \\
\text { (valor de p) }\end{array}$} & \multirow[t]{2}{*}{ OR } & \multirow[t]{2}{*}{$95 \%$ IC } \\
\hline & Caso & Control & & & \\
\hline DRB1*-128 [C/T] & $0.73 / 0.27$ & $0.6 / 0.4$ & 0.19 & 0.54 & $0.22-1.3$ \\
\hline $\mathrm{DRB} 1 * 69[\mathrm{C} / \mathrm{T}]$ & $0.69 / 0.31$ & $0.56 / 0.44$ & 0.33 & 0.58 & $0.22-1.53$ \\
\hline DQA $1 *-85[\mathrm{~A} / \mathrm{T}]$ & $0 / 1$ & $0.06 / 0.94$ & 0.38 & Inf & 0.04 -inf \\
\hline DQA $1 * 38[\mathrm{C} / \mathrm{T}]$ & $1 / 0$ & $1 / 0$ & 1 & ND & ND \\
\hline DQB1*-272 [TAAC/ - ] & $0.1 / 0.9$ & $0.18 / 0.82$ & 0.66 & 0.47 & $0.05-2.89$ \\
\hline $\mathrm{DQB} 1 *-256[\mathrm{G} / \mathrm{T}]$ & $1 / 0$ & $1 / 0$ & 1 & ND & ND \\
\hline $\mathrm{DQB}^{*}-170[\mathrm{G} / \mathrm{A}]$ & $0.38 / 0.66$ & $0.52 / 0.48$ & 0.2 & 1.8 & $0.76-4.4$ \\
\hline DQB1*-154 [C/T] & $0.45 / 0.55$ & $0.72 / 0.28$ & 0.016 & 3 & $1.25-7.68$ \\
\hline DQB1*-105 [A/T] & $0.98 / 0.02$ & $1 / 0$ & 0.47 & ND & ND \\
\hline DQB1-87 [C/T] & $0.28 / 0.72$ & $0.44 / 0.56$ & 0.17 & 2 & $0.81-5.1$ \\
\hline $\mathrm{DQB} 1 *-71[\mathrm{C} / \mathrm{T}]$ & $0.8 / 0.2$ & $0.68 / 0.32$ & 0.22 & 0.53 & $0.19-1.4$ \\
\hline $\mathrm{DQB} 1 * 46[\mathrm{G} / \mathrm{A}]$ & $1 / 0$ & $1 / 0$ & 1 & ND & ND \\
\hline
\end{tabular}

Tabla 3.22. Frecuencia haplotípica estimada en el grupo caso y control para los promotores de los genes DLA-DRB1 y DLA-DQB1. La frecuencia de cada haplotipo dentro de cada grupo fue comparada usando el test exacto de Fisher y Odds ratio (OR). IC (Intervalo de confianza). ND ( no determinado).

\begin{tabular}{lccccc}
\hline Haplotipo & Frecuencia haplotípica & $\begin{array}{c}\text { Test exacto de } \\
\text { Fisher } \\
\text { (valor de p) }\end{array}$ & OR & $\mathbf{9 5 \%}$ IC \\
& Caso & Control & & & \\
\hline URR-DRB1*CC & 0,36 & 0,26 & 0,67 & 0,79 & $0,34-1,83$ \\
URR-DRB1 ${ }^{*}$ TT & 0,2 & 0,18 & 0,67 & 0,79 & $0,34-1,83$ \\
URR-DQB*TATC & 0,54 & 0,25 & $\mathbf{0 , 0 0 6}$ & $\mathbf{3 , 0 8}$ & $1,43-8$ \\
URR-DQB*CACC & 0,23 & 0,40 & 0,07 & 0,4 & $0,18-1,05$ \\
URR-DQB*CATT & 0,17 & 0,29 & 0,22 & 0,45 & $0,19-1,31$ \\
URR-DQB*CACT & 0,04 & 0,045 & 1 & 0,53 & $0,13-4,97$ \\
URR-DQB*CTCT & 0,02 & 0 & 1 & 0,85 & $0,1-65,25$ \\
\hline
\end{tabular}


Se evaluó la hipótesis de que la homocigosis de los genes del MHC incrementa el riesgo de susceptibilidad a las enfermedades autoinmunes independientemente de la combinación de alelos presentes. Para confirmarlo se estimaron las $h_{o}, h_{e} y$ el HWE en toda la muestra y dentro de cada grupo (caso y control). Además, se calculó el OR para comparar los rangos de genotipos homocigotas/heterocigotas en ambos grupos. Los resultados obtenidos se muestran en la Tabla 3.23. Aunque todos los SNPs de las regiones reguladoras se encontraban en HWE tanto en los grupos caso como en el de animales controles, los resultados mostraron que los perros homocigotas para DRB1*69 [C/T] poseían más riesgo para desarrollar QSC que los perros heterocigotas $(\mathrm{p}=0.048 ; \mathrm{OR}=4.2$, $95 \% \mathrm{CI}=1.07-18.21$, Tabla 3.23). Estos resultados se encuentran en concordancia con los resultados reportados previamente por Jokinen y colaboradores (2011). Para el resto de los polimorfismos no se observaron diferencias significativas. 
Tabla 3.23. Análisis del equilibrio de Hardy-Weinberg (HWE) para cada polimorfismo de los promotores de los genes DLA-DRB1, DLA-DQA1 y DLA-DQB1 dentro de los grupos caso y control utilizando el índice $\mathrm{F}_{\mathrm{IS}}$.Las proporciones de homocigotas/heterocigotas entre ambos grupos fueron comparadas mediante el test exacto de Fisher y Odds ratio (OR). IC (Intervalo de confianza). ND (no determinado).

\begin{tabular}{|c|c|c|c|c|c|}
\hline Polimorfismo & $\begin{array}{c}\text { HWE } \\
\text { F }_{\text {IS }}-\text { p } \\
\text { Caso }\end{array}$ & $\begin{array}{c}\text { HWE } \\
\text { Fis }-p \\
\text { Control }\end{array}$ & $\begin{array}{l}\text { Test exacto de Fisher } \\
\text { (valor de p) }\end{array}$ & OR & $95 \%$ IC \\
\hline DRB1*-128[C/T] & $0.16-0.65$ & $-0.39-0.09$ & 0.14 & 2.83 & $0.86-9.96$ \\
\hline DRB1*69 [C/T] & $0.16-0.65$ & $-0.39-0.09$ & 0.048 & 4.2 & $1.07-18.21$ \\
\hline DQA $1 *-85[\mathrm{~A} / \mathrm{T}]$ & $-0.02-1$ & ND & 1.00 & 1.21 & $0.01-100.77$ \\
\hline DQA1* $38[\mathrm{C} / \mathrm{T}]$ & ND & ND & ND & ND & ND \\
\hline DQB1*-272 [TAAC/ - ] & $1-0.033$ & ND & ND & ND & ND \\
\hline DQB1*-256 [G/T] & ND & ND & 1 & 0 & $0-\inf$ \\
\hline DQB1*-170 [G/A] & $-0.23-0.4$ & $-0.27-0.36$ & 0.76 & 1.26 & $0.36-4.42$ \\
\hline DQB1*-154 [C/T] & $-0.07-1$ & $0.1-1$ & 0.07 & 3.48 & $0.99-13.47$ \\
\hline DQB1*-105 [A/T] & ND & ND & 0.47 & 0 & $0-35.6$ \\
\hline DQB1-87 [C/T] & $-0.1-1$ & $-0.18-0,63$ & 0.76 & 1.32 & $0.4-4.57$ \\
\hline DQB1*-71[C/T $]$ & $0.07-1$ & $0.47-0.06$ & 0.5 & 0.58 & $0.12-2.4$ \\
\hline $\mathrm{DQB} 1 * 46[\mathrm{G} / \mathrm{A}]$ & ND & ND & ND & ND & ND \\
\hline
\end{tabular}

\subsubsection{Segundo exón de los genes DLA-DRB1, DLA-DQA1 y DLA-DQB1}

La asociación entre la QSC y los alelos/haplotipos de las regiones presentadoras de antígenos de los tres genes de clase II del DLA se evaluó utilizando un clásico estudio de caso-control. Con este propósito, se estimaron las frecuencias alélicas y la heterocigocidad observada y esperada dentro de los grupos caso y control de los tres genes DLA-DRB1, DLA-DQA1 y DLA-DQB1 (Tabla 3.24). Los resultados obtenidos mostraron una asociación significativa entre el desarrollo de QSC y el alelo DLA-DQA1*00101 ( $\mathrm{p}=$ 
$0,013, \mathrm{OR}=0,12$, IC $95 \%=0,04-0,75)$, lo que sugiere un menor riesgo a presentar la enfermedad en los animales portadores de esta variante (alelo protector). El resto de los polimorfismos no mostraron asociaciones significativas. Como en el caso de las regiones reguladoras de estos loci, también se evaluó la hipótesis de que la homocigosis de los genes del MHC incrementa el riesgo de susceptibilidad a la QSC. Para confirmarlo se estimaron las heterocigocidades dentro de cada grupo (caso y control). Sin embargo, no se observó asociación significativa entre la heterocigocidad y la QSC en ninguno de los tres genes (Tabla 3.25).

Tabla 3.24. Análisis de asociación entre el desarrollo de QSC y los alelos de los exones 2 de los genes DLA-DRB1, -DQA1 y DQB1. OR (Odds ratio). IC (Intervalo de confianza). En negrita se marcan los valores significativos.

\begin{tabular}{|c|c|c|c|c|c|}
\hline \multirow{3}{*}{ Alelo } & \multicolumn{2}{|c|}{ Frecuencia alélica } & \multirow{3}{*}{$\begin{array}{l}\text { Test exacto } \\
\text { de Fisher } \\
\text { (valor de p) }\end{array}$} & \multirow[t]{3}{*}{ OR } & \multirow[t]{3}{*}{$95 \%$ IC } \\
\hline & & & & & \\
\hline & Caso & Control & & & \\
\hline DLA-DRB1*01101 & 0,48 & 0,4 & 0,65 & 1,17 & $0,53-3,15$ \\
\hline DLA-DRB1*01501 & 0,23 & 0,18 & 0,78 & 1,14 & $0,45-3,99$ \\
\hline DLA-DRB1*00101 & 0,11 & 0,03 & 0,22 & 2 & $0,48-20$ \\
\hline DLA-DQA1*00101 & 0,05 & 0,28 & $\mathbf{0 , 0 1 3}$ & 0,12 & $0,04-0,75$ \\
\hline DLA-DQA1*00201 & 0,41 & 0,46 & 0,48 & 1,35 & $0,6-3,72$ \\
\hline DLA-DQA1*00401 & 0,09 & 0,11 & 0,7 & 1,05 & $0,32-6,11$ \\
\hline DLA-DQA1*00601 & 0,26 & 0,25 & 0,79 & 0,72 & $0,3-2,25$ \\
\hline DLA-DQB1*00201 & 0,2 & 0,12 & 0,09 & 0,03 & $0,11-1,09$ \\
\hline DLA-DQB1*00301 & 0,1 & 0,12 & 1 & 0,9 & $0,3-4,25$ \\
\hline DLA-DQB1 *01302 & 0,36 & 0,45 & 0,06 & 2,18 & $0,97-6$ \\
\hline DLA-DQB1*02301 & 0,1 & 0,09 & 1 & 0,7 & $0,22-3,6$ \\
\hline DLA-DQB1*00802 & 0,1 & 0,07 & 0,46 & 0,42 & $0,14-2,36$ \\
\hline
\end{tabular}


Tabla 3.25. Análisis de asociación entre el desarrollo de QSC y la heterocigocidad observada $\left(\mathrm{h}_{\mathrm{o}}\right)$ para los alelos de los exones 2 del gen DLA-DRB1, DLA-DQA1, DLADQB1. OR (Odds Ratio). IC (Intervalo de Confianza).

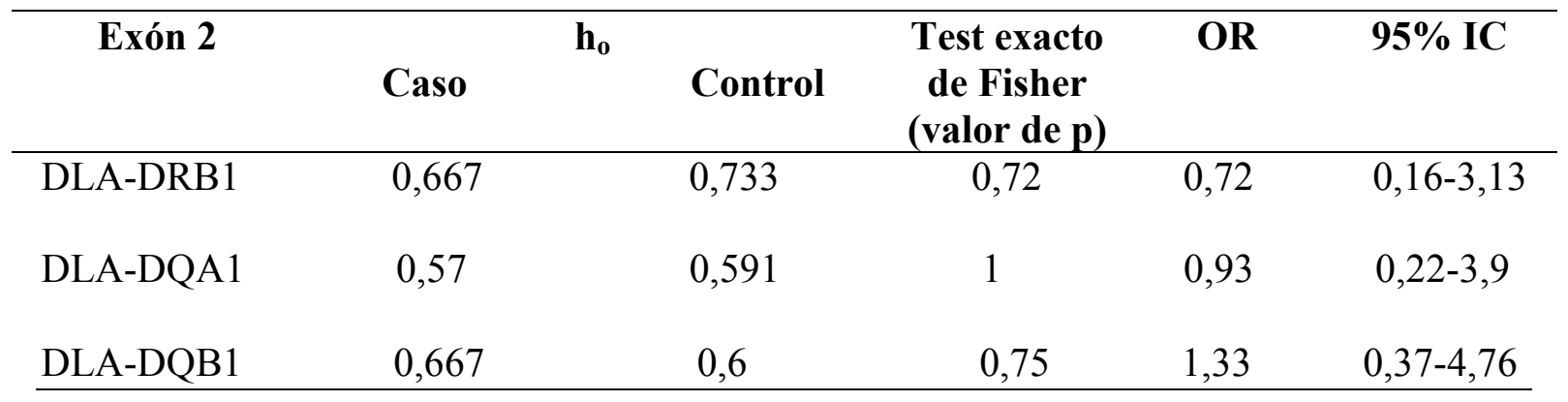

En conclusión, en los tres grupos de marcadores utilizados (microsatélites, regiones reguladoras proximales y exones 2) para el estudio de asociación se observaron alelos asociados significativamente con el desarrollo de la QSC, evaluados por separado. Luego se determinó el desequilibrio de ligamiento ( $\mathrm{LD}$, en valores de $\mathrm{D}^{\prime}$ ) entre todos los loci utilizando el software Pypop (Tabla 3.26). Del análisis multilocus de los tres microsatélites se obtuvieron 141 haplotipos diferentes, con frecuencias haplotipicas entre 0,014 y 0,06 por lo que no fueron muy útiles para realizar un estudio de asociación. Es por esta razón que se procedió a realizar los estudios de asociación entre los haplotipos conformados por los alelos de las regiones presentadoras de antígenos de los tres genes de clase II y el desarrollo de QSC. Este análisis puso en evidencia diferencias significativas entre los grupos caso y control en la distribución del haplotipo 3 ( $\mathrm{p}=0,02, \mathrm{OR}=0,2$, IC $95 \%=0,07-0,81$; Tabla 3.27), debido a que esta combinación resultó ser significativamente más frecuente en los individuos sanos que en los enfermos, los resultados obtenidos sugerirían un rol protector para el desarrollo de QSC. Este resultado coincide con los resultados de la asociación con los exones 2 en forma individual, ya que este haplotipo contiene el alelo protector DLADQA*00101 (Tabla 3.27, Figura 3.4). 
Tabla 3.26. Desequilibrio de ligamiento medido en $\mathrm{D}^{\prime}$ entre todos los loci analizados (Pypop software).

\begin{tabular}{|c|c|c|c|}
\hline \multirow[t]{2}{*}{ Pares de loci } & \multicolumn{3}{|c|}{ Desequilibrio de Ligamiento [D'] } \\
\hline & $\begin{array}{l}\text { Población } \\
\text { total }\end{array}$ & Caso & Control \\
\hline URR-DRB1/DRB1 exón2 & 0,87 & 0,85 & 1 \\
\hline DRB1 exón2/DQA1 exón2 & 0,8 & 0,91 & 0,86 \\
\hline DQA1 exón2/URR-DQB1 & 0,6 & 0,77 & 0,63 \\
\hline URR-DQB1/DQB1 exón2 & 0,8 & 0,92 & 0,67 \\
\hline DQB1 exón2/FH2202 & 0,73 & 0,84 & 0,8 \\
\hline FH2202/FH2975 & 0,82 & 0,8 & 0,87 \\
\hline FH2975/FH2054 & 0,56 & 0,6 & 0,7 \\
\hline
\end{tabular}

Tabla 3.27. Análisis de asociación entre el desarrollo de QSC y los haplotipos conformados por las regiones presentadoras de antígenos de los genes de clase II DLADRB1, DLA-DQA1 y DLA-DQB1. OR (Odds ratio). IC ( Intervalo de confianza). En negrita se marca el valor significativo.

\begin{tabular}{ccccccc}
\hline \multicolumn{1}{c}{ Haplotipo } & \multicolumn{2}{c}{$\begin{array}{c}\text { Frecuencias } \\
\text { haplotípicas } \\
\text { Caso }\end{array}$} & $\begin{array}{c}\text { Test exacto } \\
\text { Control }\end{array}$ & $\begin{array}{c}\text { OR } \\
\text { (valor de p) }\end{array}$ & 95\% IC \\
& & 0,53 & 0,32 & 0,6 & 2,32 & $1,002-6,59$ \\
\hline $\mathbf{1}$ & $01101 / 00201 / 01302$ & 0,13 & 0,12 & 1 & 1,04 & $0,2-5,74$ \\
$\mathbf{2}$ & $01501 / 00601 / 00301$ & 0,11 & 0,32 & $\mathbf{0 , 0 2}$ & 0,2 & $0,07-0,81$ \\
$\mathbf{3}$ & $00101 / 00101 / 00201$ & 0,11 & 0,12 & 1 & 0,63 & $0,2-3,27$ \\
\hline & $01501 / 00601 / 02301$ & & & & & \\
\hline
\end{tabular}


Figura 3.4. Distribución de los haplotipos detectados en los grupos caso y control. Se marcó con una flecha el haplotipo 3, el cual evidenció diferencias significativas (haplotipo protector).

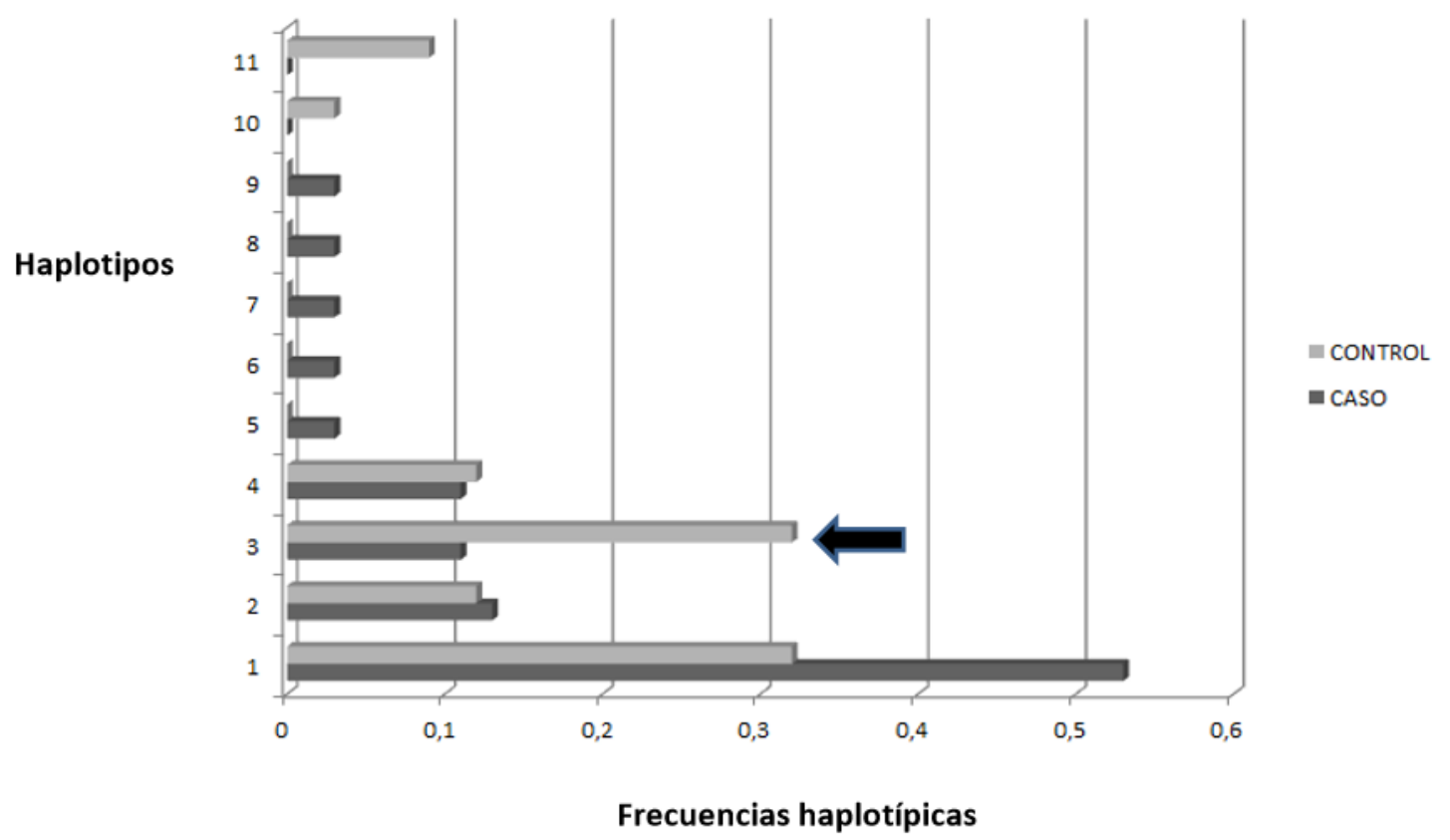

Para finalizar se evaluó la asociación entre los haplotipos conformados por la región reguladora proximal y su correspondiente región presentadora de antígenos (exón 2) del gen DLA-DQB1y el riesgo a desarrollar QSC. La determinación de estos haplotipos y de sus frecuencias alélicas se llevó a cabo usando el software Pypop. Cabe mencionar que solo se tuvieron en cuenta las combinaciones más representadas, y que en este caso los loci analizados presentaban un $\mathrm{LD}=0,92\left(\mathrm{D}^{\prime}\right)$. Los resultados de asociación obtenidos mostraron diferencias significativas entre el haplotipo URR-DQB*TATC/*01302 y el desarrollo de QSC ( $\mathrm{p}=0,003$, OR=4,56, 95\% IC=1,74-16,53) (Tabla 3.28), lo que sugiere que los animales portadores de esta combinación poseen cinco veces más riesgo a desarrollar QSC. 
Tabla 3.28. Frecuencias haplotípicas de las regiónes promotoras y presentadoras de antígenos del gen DLA-DQB1 (URR-DQB/exón 2 DQB1) y análisis de asociación. OR (Odds Ratio). IC (Intervalo de Confianza).

\begin{tabular}{cccccc}
\hline Haplotipo & $\begin{array}{c}\text { Frecuencia } \\
\text { haplotípica }\end{array}$ & $\begin{array}{c}\text { Test exacto } \\
\text { de Fisher } \\
\text { (valor de } \\
\text { p) }\end{array}$ & OR & 95\% IC \\
& Caso & Control & & & \\
\hline URR-DQB*TATC/*01302 & 0,5 & 0,15 & $\mathbf{0 , 0 0 3}$ & 4,56 & $1,74-16,53$ \\
URR-DQB*CACC/*00301 & 0,15 & 0,12 & 0,25 & 0,24 & $0,072-1,58$ \\
URR-DQB*CATT/*00201 & 0,06 & 0,16 & 1 & 1 & $0,33-4,85$ \\
URR-DQB*CACC/*02301 & 0,09 & 0,06 & 1 & 1 & $0,26-7,87$ \\
\hline
\end{tabular}




\section{4- DISCUSIÓN}




\section{4- DISCUSIÓN}

En cuanto al estudio retrospectivo realizado colaboración con Servicio de Clínica de Pequeños Animales, Hospital de Clínicas (Facultad de Ciencias Veterinarias, Universidad Nacional de La Plata) se recolectó información de pacientes caninos sobre edad, sexo, raza y motivos de consulta $(n=752)$, en un período comprendido entre el año 2009 y 2011. Como resultado de este relevamiento se observó una incidencia de la QSC de 5,46\%. Dentro de este grupo de animales el $78 \%$ eran de la raza ovejero alemán. La edad de presentación promedio fue 5,5 años. Dentro los caninos afectados, la relación hembra: macho fue de 1,15:1. Este estudio confirma que el Ovejero Alemán, una de las principales razas que se crían en nuestro país, es la raza más afectada por QSC. Además, cabe destacar que la QSC es una de las enfermedades de origen genético más importante en esta raza. En cuanto a la predisposición sexual, se muestran diferencias con los autores Gelatt (1999), Bedford (1981) y Maggs (2009) quienes reportan que las hembras están más afectadas que los machos. Por el contrario, en este estudio no se observó diferencias en la predisposición a desarrollar QSC entre hembras y machos. La edad promedio de presentación fue de 5,5 años, coincidente con reportes anteriores donde se informó un rango etario de entre 1 y 6 años de edad en Ovejeros Alemanes (Jokinen y col., 2011).

Estudios previos han propuesto que la QSC es una enfermedad autoinmune. Entre las evidencias que apoyan esta hipótesis se encuentra el hecho que se ha reportado la sobreexpresión de los genes de clase II en las corneas afectadas (Williams, 2005). Además, la importancia de la respuesta inmune anómala en el desarrollo de la enfermedad queda en evidencia por su respuesta al tratamiento con fármacos inmunosupresores como los corticoides y ciclosporina (Pérez, 2004). Es por esta razón que para el estudio de asociación entre polimorfismos genéticos y el desarrollo de la QSC se seleccionó la región del DLA de clase II ubicada en el cromosoma 12 canino, debido a que estos genes codifican a los receptores más efectivos en la presentación de antígenos propios, los cuales activan a los linfocitos T autoreactivos. Por lo tanto, los loci de clase II presentadores de antígenos, tales como los genes DLA-DRB1, DLA-DQA1 y DLA-DQB1, son los principales genes candidatos para estudiar las enfermedades autoinmunes (Day y Shultz, 2014). Por otra parte, numerosos trabajos han reportado asociaciones significativas entre loci de clase II y enfermedades autoinmune en humanos, animales de experimentación y animales 
domésticos (Ollier y col., 2001; Kennedy, 2006; Kennedy, 2007; Wilbe y col. , 2010; It y col., 2010; Quinnell y col., 2003, Kasper y col., 2014 ). Entre ellas pueden mencionarse el Lupus eritematoso sistémico, la enfermedad de Addison y Diabetes Mellitus, de gran importancia debido a las similitudes fisiopatológicas con la especie humana. Basado en estas evidencias, en el presente trabajo de Tesis Doctoral se eligieron tanto las regiones promotoras proximales como las regiones presentadoras de antígenos de los genes de clase II DLA-DRB1, DLA-DQA1 y DLA-DQB1. Estos genes son los tres genes funcionales de clase II canino que presentan mayor nivel de polimorfismo. Además, el estudio se complementó con la tipificación de tres microsatélites cercanos a estas regiones (Figura 2.4).

En una primera etapa se tipificaron tres microsatélites ubicados próximos a la región de clase II del DLA. Los resultados obtenidos en este análisis mostraron que, si bien los tres marcadores genéticos elegidos presentaron variabilidad alélica, la mayoría de los alelos detectados evidenciaron una baja frecuencia en la población estudiada. Por esta razón se realizaron los estudios de asociación para las variantes que al menos estaban en una frecuencia mayor a 0,1 , dos de los tres microsatélites elegidos mostraron una asociación significativa con el desarrollo de la QSC. En este sentido, alelos de los STRs FH2054 (FH2054*172) y FH2975 (FH2975*320) presentaron asociaciones significativas con un mayor riesgo a desarrollar QSC. Por el contrario, no se observaron asociaciones significativas con el microsatélite FH2202, a pesar de ser el marcador genético más cercano a la región de clase II del DLA. Los resultados obtenidos a partir de la genotipificación de los microsatélites constituyen una primera aproximación para apoyar la hipótesis que genes de la región cromosómica de clase II del DLA estarían asociados al desarrollo de QSC. Esto afirmación sería confirmada posteriormente con la tipificación de los genes de clase II (regiones reguladora proximal y presentadora de antígenos), lo cual se discutirá más adelante.

En una segunda etapa se evaluaron los polimorfismos (SNPs e INDELs) dentro de dos regiones de importancia funcional para los genes de clase II, las que están involucradas en la regulación de la expresión génica y en el reconocimiento y presentación de los antígenos. En la población de ovejeros alemanes estudiada se detectaron con frecuencias apreciables los dos alelos reportados para el promotor del gen DLA-DRB1. Trabajos 
previos mostraron que el alelo DRBp*1 (variante C del DRB1*-128 [C/T]) es el más común en perros y está fijada en algunas razas (por ej., Rottweiler, Airedale Terrier, Irish Setter, Cocker Spaniel y Boston Terrier). De todas maneras, los resultados obtenidos están en concordancia con los datos reportados en la raza ovejero alemán $(C=0,58$ y $T=0,42$; Berggren y Seddon, 2005). En cuanto a los SNPs que fueron reportados en perros y lobos en el gen DLA-DQA1, el primero corresponde a una transversión A/T localizada en una TATA Box en posición-85 dentro del promotor y el segundo a una sustitución sinónima en la posición 69 del exón 1 del gen. Los alelos T del SNP DQA1*-85 [A/T] y C del SNP DQA1* $38[\mathrm{C} / \mathrm{T}]$ fueron las variantes más comunes en perros, mientras que los alelos A del SNP DQA1*-85 [A/T] y T del DQA1* $38[\mathrm{C} / \mathrm{T}]$ solo fueron identificados en las razas Doberman Pinscher, English Springer Spaniel y Saluki. Por lo tanto, estas variantes no estaban reportadas en el ovejero alemán (Berggren y Seddon, 2005). En concordancia con los estudios previos, el análisis de la población de ovejeros alemanes de nuestra región mostró que el alelo $\mathrm{C}$ del DQA1* $38[\mathrm{C} / \mathrm{T}]$ estaba fijado, mientras que la variante $\mathrm{T}$ del SNP DQA1*-85 [A/T] se encontraba cercano a la fijación. La variante A del DQA1*-85 $[\mathrm{A} / \mathrm{T}]$ solo se observó en dos animales heterocigotas (frecuencia alélica $=0,02$ ). La ausencia de esta variante en ovejeros alemanes en los reportes previos podría deberse a efectos de muestreo. Por otra parte, la baja variabilidad del promotor de este gen con respecto a otras razas caninas puede explicarse por los altos niveles de diferenciación interracial y por lo bajos niveles de diversidad intraracial producto de la alta consanguinidad, reducido número de individuos fundadores, al tamaño efectivo de la población y a la presencia de barreras raciales. Esto ha llevado a que muchos SNPs solo presenten polimorfismos en algunas razas o grupos raciales. Esto se ve reflejado en la distribución de las enfermedades de origen genético en esta especie. Aunque este patrón es común en las especies domésticas, es mucho más marcado en la especie canina (van Steenbeek y col., 2016).

Berggren y Seddon (2005) reportaron siete SNPs y dos INDELs en el gen DLADQB1 en diferentes razas de perros y el lobo, siendo el SNP DQB1*46 [G/A] especifico del lobo. Esto último explicaría porque en el presente estudio no se detectó la mutación A/G (no sinónima) en la posición 46 del exón 1 del gen DLA-DQB1. Además, tampoco, se observaron nuevos polimorfismos para este locus. Los resultados obtenidos coinciden con 
los reportados previamente, ya que se detectaron los mismo polimorfismos con frecuencias similares, con excepción del INDEL DQB1*-272 [TAAC/-] (Berggren y Seddon, 2005). Esta inserción se encontró en muy baja frecuencia en la población de ovejeros alemanes estudiada, en contraste con lo reportado en Escandinavia donde ambas variantes presentaban frecuencias alélicas similares (Berggren y Seddon, 2005).

Los resultados obtenidos del análisis de LD permitieron identificar dos bloques haplotípicos. Este hecho es esperable debido a que a pesar de que los genes de clase II del DLA encuentran próximos en el cromosoma 12 canino, se ha reportado que en los genomas de mamíferos solo se alcanza un alto LD a distancias genéticas muy pequeñas $(<100 \mathrm{~kb}$; Goddard y Hayes, 2012; Axelsson, 2012). En este sentido, los genes DLA-DRB1 y DLADQA1 se encuentran a una distancia genética de aproximadamente $70 \mathrm{~kb}$, mientras que entre el DLA-DQA1 y el DLA-DQB1 hay una distancia de aproximadamente $30 \mathrm{~kb}$, por lo que la distancia total entre los genes más alejados $(100 \mathrm{~kb})$ es lo suficientemente grande para que se pierda el LD por efecto de la recombinación. Como consecuencia de ello, los dos bloques detectados estaban conformados por polimorfismos de un mismo gen (DLADRB1 y DLA-DQB1). En el caso del gen DLA-DRB1, los haplotipos detectados corresponden a los alelos reportados previamente: DLA-DRB1*1 y DLA-DRB1*2. En cuanto al gen DLA-DQB1, se detectaron los haplotipos DLA-DQBp*2, DLA-DQBp*3, DLA-DQBp*6 y DLA-DQBp*7, que fueron reportados previamente por Berggren y Seddon (2005). Además, se detectó el haplotipo DLA-DQBp*4 (denominado en el presente estudio DLA-URR-DQB*CATT) con una frecuencia génica de 0,2 , siendo identificado por primera vez en la raza Ovejero alemán. Como se discutió anteriormente, estas diferencias entre poblaciones de ovejeros alemanes de distintas regiones geográficas pueden ser consecuencia de la estructura y dinámica poblacional característica de las razas caninas. Finalmente, cabe mencionar que la fase de ligamiento del gen DLA-DQA no pudo ser analizada debido a que casi todos los animales presentaron genotipos homocigotas para el mismo genotipo para ambos SNPs. En este caso, también los resultados obtenidos concuerdan con lo observado en otras poblaciones de ovejeros animales.

Las variaciones en los niveles de la respuesta inmune entre individuos/poblaciones han sido explicadas mediante diferentes mecanismos, tales como diferencias en el reconocimiento y presentación de antígenos, en los niveles de expresión génica y en el 
grado de homocigosis (Fernando y col., 2008). La expresión de las moléculas del MHC de clase II está principalmente regulada a nivel transcripcional por un proceso complejo que involucra secuencias altamente conservadas localizadas en las regiones reguladoras de los genes de clase II. Estas unidades reguladoras comprenden a seis secuencias ( $\mathrm{S}, \mathrm{X}, \mathrm{X} 2, \mathrm{Y}$, CCAAT y TATA boxes), que están altamente conservadas en los vertebrados (Handunnetthi y col., 2010). Estas secuencias representan sitios de interacción con factores de transcripción nucleares como NF-YB, NF-YC, RFX5, RFXANK y CREB-1, los cuales forman un "transcriptosoma" con el transactivador de clase II (CIITA) y median el control transcripcional (Ting y col., 2002). Además, estas secuencias regulatorias son necesarias para la correcta expresión constitutiva e inducidas por citoquinas. Por lo tanto, los polimorfismos a ese nivel podrían tener consecuencias funcionales en su actividad transcripcional (Louis y col., 1994; Singal y col., 1994, 1996; Janitz y col., 1997).

La sobreexpresión de las moléculas del MHC de clase II que ocurre en la QSC, la cual está regulada por el IFN-gamma secretado por el infiltrado celular de linfocitos T CD4+, que reconoce las regiones reguladoras a través de un complejo de factores de transcripción haciendo que células como fibroblastos o epiteliales expresen moléculas de clase II como si fueran "celulas presentadoras de antígenos temporarias” (Andersen y col., 1991; Williams, 2005). Considerando tanto esto como el rol de las regiones reguladoras en el control transcripcional, se puede suponer que los polimorfismos dentro de las cajas regulatorias podrían modificar los niveles de expresión génica y por lo tanto la respuesta inmune. De todos los polimorfismos detectados en el presente estudio solo dos se localizan dentro de secuencias de reconocimiento de factores de transcripción: SNP DQB1*-154 [C/T] y SNP DLA-DQA1*-85[A/T]. El SNP DQB1*-154 [C/T] está localizado en el extremo 3' de la caja reguladora X2, y además, evidenció una asociación significativa con un mayor riesgo a desarrollar QSC. Por lo que se podría hipotetizar que el cambio en la caja regulatoria X2 podría afectar el nivel y/o patrón de expresión del gene clase II DLA-DQB1 en la QSC, y de esta forma explicar la asociación observada. De todas maneras, el rol funcional de este sitio polimórfico necesita ser confirmado por estudios de expresión génica. Cabe recordar que el SNP DLA-DQA1*_85[A/T] se encuentra en la caja regulatoria Y del promotor, pero que en este caso el polimorfismo no fue informativo debido a que se su variante $\mathrm{T}$ se encuentra prácticamente fijada en la raza estudiada. 
Varios estudios muestran que la heterocigosidad confiere una ventaja contra enfermedades infecciosas y enfermedades autoinmunes en diferentes especies de mamíferos, como por ejemplo humanos y bovinos (Thursz y col., 1997; Hraber y col., 2007; Takeshima y col., 2008), En caninos, se asoció la homocigosis de los genes DLA case II a la mayor predisposición a desarrollar enfermedades autoinmunes, como en SLE, Enfermedad de Addison (Hughes y col., 2010; Wilbe y col., 2010). En este sentido, Jokinen (2011) asoció los niveles de homocigosis con un mayor riesgo o predisposición a desarrollar QSC (OR: 4,37; $\mathrm{p}=0,02)$. Sin embargo, en este estudio no se observaron asociaciones significativamente entre la homocigocidad y la mayoría de los marcadores utilizados, que un mayor riesgo al desarrollo de la enfermedad. La excepción a esto fue el SNP DRB1*69 [C/T] localizado al inicio del exón 1 del gen DLA-DRB1. En este caso los perros homocigotas para este polimorfismo poseían más riesgo para desarrollar QSC que los perros heterocigotas $(\mathrm{p}=0.048 ; \mathrm{OR}=4.2,95 \% \mathrm{CI}=1.07-18.21)$.

El análisis de los polimorfismos del exón 2 (región presentadora de antígenos, ARS) de los genes DLA-DRB1, DLA-DQA1 y DLA-DQB1 presentó suficiente variabilidad genética, tanto en el grupo caso como control, como para realizar el estudio de asociación. Sin embargo, solo se detectaron 15 de los 52 haplotipos reportados para el gen DLADRB1, 7 de los 16 alelos reportados para el gen DLA-DQA1 y 13 de los 36 alelos reportados para el gen DLA-DQB1. Además, en los tres genes se observaron diferencias significativas con las proporciones esperadas del HWE atribuidas a la elevada homocigosis. Esto es esperable debido a diferentes factores genéticos poblacionales. El reducido número de animales fundadores y la presencia de barreras raciales han tenido como consecuencias que la excepcional variabilidad genética de estos genes de clase II esté fraccionada entre las diferentes razas o grupos raciales. Es por esta razón, que por ejemplo en el caso de los genes analizados se detectaron aproximadamente un tercio de los alelos reportados (Hedrick, 2005). Este efecto no se ve tan marcado en el caso de los SNPs bialélicos, como por ejemplo el promotor del gen DLA-DRB1. Por otra parte, dentro de cada raza la población usualmente está dividida en criaderos de pocos reproductores, por lo que el aumento significativo de la homocigosis observado en el presente estudio podría deberse al efecto Wahlund. El uso de uno o unos pocos reproductores machos portadores de una pocas variantes en particular produce su aumento en esta subpoblación con respecto al resto, 
produciendo variaciones entre las frecuencias alélicas de los diferentes criaderos. Esta explicación puede ser aplicada a la muestra analizada ya que los animales incluidos provienen de diferentes criaderos y explicaría que la mayoría de los marcadores se encuentren en desequilibrio de HWE. Además, este efecto podría enmascarar la mayor predisposición de los homocigotas a desarrollar QSC.

En cuanto a la distribución haplotípica dentro de la población de estudio se hallaron 11 haplotipos de los exones 2 DLA-DRB1/DLA-DQA1/DLA-DQB1 en el total de la población, pero solo cuatro con una frecuencia apreciable para hacer los estudios de asociación. Las variantes más comunes halladas en otros países coinciden con las encontradas en este estudio. La frecuencia del haplotipo más común en ovejeros alemanes, DLA-DRB1*01101/DQA1*00201/DQB1*01302 fue de 0,43, mientras que en otras poblaciones como las de Estados Unidos, Reino Unido y Finlandia, fue en promedio del 0,4 (Tsai y col., 2013; Wilbe y col., 2010; Jokinen, 2011).

Una vez genotipados los animales para los exones 2 de los tres genes, se realizó el análisis de asociación entre los polimorfismos de esta región y el desarrollo de QSC con el clásico diseño de caso-control. Se observaron diferencias significativas solo entre el haplotipo DRB1*00101/DQA1*00101/DQB1*00201 y el desarrollo de QSC, indicándolo con haplotipo protector. Sin embargo, el haplotipo de riesgo DRB1*01501/DQA1*00601/DQB1*00301 reportado por Jokinen (2011), presentó en este estudio una frecuencia génica de 0,125 en la población total y no evidenció diferencias significativas entre los grupos caso y control. Mientras que en otras poblaciones de ovejeros alemanes presentaron una frecuencia alélica de 0,27 (Tsai y col., 2013, Jokinen y col., 2011). Estas diferencias dentro de la misma raza pero en poblaciones diferentes pueden deberse a las diferentes presiones de selección que hayan recibido (Clatworthy y col., 2007).

Finalmente, se evaluó el haplotipo conformado por las regiones reguladoras y el exón 2 del gen DLA-DQB1. Este tipo de análisis no se ha hecho en otros trabajos de asociación entre enfermedades inmunomediadas y el MHC clase II. Se encontró una asociación significativa entre el haplotipo URR-DQB*TATC/*01302 ( $\mathrm{p}=0,003)$ y la enfermedad, aumentando el riesgo a desarrollar QSC en 5 veces. Cabe recordar el promotor URRDQB*TATC también evidenció una asociación significativa cuando fue analizado en forma independiente y que el alelo *01302, el más frecuente en la raza OA, mostró un valor 
de $\mathrm{p}$ cercano al límite de significancia $(\mathrm{p}=0,06)$. Además, estos dos loci mostraron valores de LD cercanos al ligamiento completo $\left(D^{\prime}=0,92\right)$ en el grupo caso. Es por estas razones que la asociación del haplotipo URR-exon 2 podría explicarse teóricamente como una sinergia entre el promotor y el exón 2, relacionado al número de transcriptos expresados del gen conjuntamente a una mayor eficiencia en el reconocimiento del antígeno. En este este sentido, Cowell (1998) y Mitchison y Roes (2002) sugirieron que la co-evolución entre estas dos regiones del gen pueden haber sido consecuencia de una selección favorable hacia alguna otra característica. El análisis de los polimorfismos en las regiones presentadoras de antígenos (exón 2) son críticas en el estudio de las enfermedades inmunomediadas ya que determinan los motivos aminoacídicos de los sitios de unión a antígenos presentes en los bolsillos de las moléculas presentadoras del MHC. La importancia de las variaciones a nivel aminoacídico fue confirmada en trabajos que analizaron las asociaciones entre la estructura proteica de las moléculas del MHC y el reconocimiento y la presentación de antígenos, por lo tanto con la respuesta inmune (Konnai y col., 2003; Yoshida y col., 2009) 


\section{5-CONCLUSIONES}




\section{5- CONCLUSIONES}

El presente trabajo de Tesis Doctoral se centró en el estudio de asociación entre los polimorfismos localizados en genes de DLA de clase II y microsatélites ligados al DLA con la patogénesis de la QSC en perros ovejeros alemanes. Las principales conclusiones obtenidas se detallan a continuación:

- Se obtuvieron por primera vez datos epidemiológicos locales sobre la prevalencia de QSC en ovejeros alemanes, no observándose diferencias significativas entre sexos.

- Los resultados obtenidos validan la asociación reportada en ovejeros alemanes (Jokinen, 2011) en una muestra independiente, perteneciente a la provincia de Buenos Aires y proveen una fuerte evidencia que avala la asociación entre los genes del MHC de clase II y el desarrollo de la QSC en perros.

- Como respuesta a la necesidad de asignar los alelos de los exones 2 se desarrolló un software que calcula las combinaciones más probables a partir de las secuencias crudas y utilizando las secuencias de alelos reportados en la base de datos IPD-MHC.

- Se han detectado por primera vez haplotipos protectores, los cuales podrían contribuir una vez validados a la selección positiva en los criaderos.

- También se evaluó la sinergia que se puede dar entre las regiones reguladoras proximales y las regiones presentadoras de antígenos en los genes del DLA de clase II, observándose la asociación entre ciertas combinaciones y el desarrollo de QSC.

- Estas asociaciones genéticas apoyan los estudios clínicos, histológicos y farmacológicos previos que indican que la QSC es una enfermedad inmunomediada (Bedford y Longstaffe, 1981; Williams, 1999, 2005). 
- Si bien la base genética de la enfermedad puede ser principalmente explicada por esta asociación con los genes del $\mathrm{MHC}$, otros genes pueden contribuir en la patogénesis y deberían ser identificados.

- Los hallazgos del presente trabajo podrían ser utilizados para identificar animales susceptibles previo a la aparición de los cambios patológicos. 


\section{6-BIBLIOGRAFÍA}




\section{6- BIBLIOGRAFÍA:}

1. Andersen LC, Beaty JS, Nettles JW, Seyfried CE, Nepom GT, Nepom BS. Allelic Polymorphism in Transcriptional Regulatory Regions of HLADQB .1991Genes. J Exp Med. 173(1), 181-192.

2. Asher L, Diesel G, Summers JF, McGreevy PD, Collins LM. Inherited defects in pedigree dogs. Part 1: disorders related to breed standards. Vet J. 2009; 182(3):402-11.

3. Axelsson E, Webster MT, Abhirami R, The LUPA Consortium, Ponting CP, Kerstin LT. Death of PRDM9 coincides with stabilization of the recombination landscape in the dog genome. Genome Research. 2012; 22, 51-63

4. Barrett JC, Fry B, Maller J, Daly MJ. Haploview: analysis and visualization of LD and haplotype maps. Bioinformatics. . 2005; 21, 263-265.

5. Bedford PGC, Longstaffe JA. Corneal pannus (chronic superficial keratitis) in the German shepherd dog. Journal of Small Animal Practice .1981; 20: 41-56.

6. Berggren K, Seddon J. MHC promoter polymorphism in grey wolves and domestic dogs. Immunogenetics. 2005; 57, 267-272.

7. Björnerfeldt S, Hailer F, Nord M, Vilà C. Assortative mating and fragmentation within dog breeds. BMC Evol Biol. 2008; 8:28.doi: 10.1186/1471-2148-8-28.

8. Brinkmeyer-Langford C, Komegay JN. Comparative Genomics of X-linked Muscular Distrophies: The Golden Retriever Model. Curr Genomics. 2013; 144:330-342. 
9. Calboli FC, Sampson J, Fretwell N, Balding DJ. Population structure and inbreeding from pedigree analysis of purebred dogs. Genetics. 2008; 179(1):593-601.

10. Chandler HL, Kusewitt DF, Colitz CM. Modulation of matrix metalloproeinases by ultraviolet radiation in the canine cornea. Vet Ophthalmol. 2008; 11:135-144.

11. Chavkin MJ, Roberts SM, Salman MD, Severin GA, Scholten NJ. Risk factors for development of chronic superficial keratitis in dogs. J Am Vet Med Assoc. 1994 204(10):1630-4.

12. Cheng S, Wigney D, Haase B, Wade CM. Inheritance of chronic superficial keratitis in Australian Greyhounds. Animal Genetics. 2016. 47:629.

13. Clatworthy MR, Willcocks L, Urban B. Systemic lupus erythematosusassociated defects in the inhibitory receptor FcyRIIb reduce susceptibility to malaria. Proc Natl Acad Sci U SA. 2007: 104: 7169-74.

14. Cowell LG, Kepler TB, Janitz M, Lauster R, Mitchison NA. The distribution of variation in regulatory gene segments, as present in MHC class II promoters. 1998. Genome Res 8:124-134

15. Davis SJM, Valla FR. Evidence for domestication of the dog 12,000 years ago in the Natufian of Israel. Nature. 1978. 276:608-10.

16. Day M. Clínical Immunology of the dog and cat, Second Edition. Manson Publishing. 2012. 
17. Day MJ, Shultz RD. Veterinary Immunology: Principles and practice. Second Edition. Taylor and Francis Group. 2014. Cap 16, pag.188.

18. de la Chapelle A, Wright FA. Linkage disequilibrium mapping in isolated populations: The example of Finland revisited. 1998. Proc. Natl. Acad. Sci. 95:12416-12423.

19. Fainboim L, Geffner J. Introducción a la Inmunología humana. 5ta Edición. Buenos Aires. Médica Panamericana. 2008.

20. Farmer A-MT. Corneal pannus in the dog. PhD Thesis, University of Cambridge, 1983.

21. Federación Cinológica Internacional. FCI, 2016. http://www.fci.be/en/.

22. Fels L, Marschall Y, Philipp U, Distl O. Multiple loci associated with canine hip dysplasia (CHD) in German sherperd dogs. 2014. Mamm Genome. 25:262269.

23. Gelatt KN. Veterinary Ophthalmology Ed. $3^{\text {a }}$. Lippincott, Williams \& Willkins. Cap 9-355-425. 1999.

24. Goddard ME, Hayes BJ. Genome-Wide Association Studies of Linkage Disequilibrium in Cattle. 2012. Bovine Genomics.192-211.

25. Gough A, Thomas A. Breed predispositions to disease in Dogs and Cats. Blackwell. 2004. 72-79. 
26. Handunnetthi L, Ramagopalan SV, Ebers GC, Knight JC. Regulation of MHC class II gene expression, genetic variation and disease. Genes Immun. 2010. 11(2), 99-112.

27. Hedrick PW. Genetics of populations. Third Edition. Jones and Barlett Publishers. Cap 6. Pag 342. 2005.

28. http://omia.angis.org.au/home/

29. Hughes AM, Jokinen P, Bannasch DL, Lohi H, Oberbauer AM.Association of a dog leukocyte antigen class II haplotype with hypoadrenocorticism in Nova Scotia Duck Tolling Retrievers. 2010. Tissue Antigens75, 684-690

30. Hraber P, Kuiken C, Yusim K. Evidence for human leukocyte antigen heterozygote advantage against hepatitis $C$ virus infection. 2007. Hepatology 46, 1713-1721.

31. It V., L. Barrientos, J. López Gappa, D. Posik, S. Diaz, C. Golijow, G. Giovambattista. Association of canine juvenile generalized demodicosis with the Dog Leukocyte Antigen System (DLA). 2010. Tissue Antigens, 76 (1): 67-70.

32. Janitz M, Mitchison A, Reiners-Schramm L, Lauster R. Polymorphic MHC class II promoters exhibit distinct expression pattern in various antigenpresenting cell lines. 1997. Tissue Antigens. 49, 99- 106.

33. Kasper KJ, Zeppa JJ, Wakabayashi AT, Xu SX, Mazzuca DM. Bacterial Superantigens Promote Acute Nasopharyngeal Infection by Streptococcus pyogenes in a Human MHC Class II-Dependent Manner. 2014. PLoS Pathog 10(5): e1004155. 
34. Kennedy LJ, Quarmby S, Happ GM .Association of canine hypothyroidism with a common major histocompatibility complex DLA class II allele. 2006. Tissue Antigens 68: 82-6.

35. Kennedy LJ. 14th International HLA and Immunogenetics Workshop: report on joint study on canine DLA diversity. 2007. Tissue Antigens, 269-271.

36. Konnai S, Nagaoka Y,Takeshima S, Onuma M, Aida Y. Sequences and diversity of 17 new Ovar-DRB1 alleles from three breeds of sheep. 2003. Immunogenetics. 30:275-282.

37. Kramer JW, Venta PJ, Klein SR, Cao Y, Schall WD, Yuzbasiyan-Gurkan V. A von Willebrand's Factor Genomic Nucleotide Variant and Polymerase Chain Reaction Diagnostic Test Associated with Inheritable Type-2 von Willebrand's Disease in a Line of German Shorthaired Pointer Dogs. 2004. Vet Pathol. 41(3):221-8.

38. Larson G, Bradley DG. How much is that in dog years? The advent of canine population genomics. PLoS Genet. 2014.10(1): e1004093.

39. Li N, Stephens M. Modeling Linkage Disequilibrium and Identifying Recombination Hotspots Using Single-Nucleotide Polymorphism Data. 2003.Genetics. 165( 4) 2213-2233

40. Lopez García MJ, Osuna Molina A, Osuna Molina R. Manual de laboratorio de las enfermedades autoinmunes digestivas. Omnia Science Publisher. 2013.

41. Lucotte G, Perramon A, Kaminski M. Molecular basis for heterosis in the chicken-quail hybrid. 1977.Comp Biochem Physiol B.56(2):119-22. 
42. Maggs D. Capítulo Córnea y esclera. En Slatter, Fundamentos de oftalmología veterinaria. $4^{\circ}$ ed. Elsevier. Barcelona (España) 2009. p. 179-206.

43. Marsili S, Genini S, Sudharsan R, Gingrich J, Aguiire GD, Beltran WA. Exclusion of the unfolded protein response in light-induced retinal degeneration in the canine T4R RHO model of autosomal dominant retinitis pigmentosa. 2015. PloS One 10.

44. Mellanby RJ, Ogden R, Clements DN, French AT, Gow AG, Powell R. Population structure and genetic heterogeneity in popular dog breeds in the UK. 2013. Vet J. 2013;196(1):92-7.

45. Mitchison NA, Roes J. Patterned variation in murine MHC promoters. 2002. Proc Natl Acad Sci USA. 99:10561-10566

46. Nei M. Estimation of average heterozygosity and genetic distance from a small number of individuals.1978. Genetics.89(3):583-90.

47. Nelson RW, Couto G. Small Animal Internal Medicine. 5ta Edición. Elseiver. 2014

48. Nemanic S, Nixon B.K, Baltzer W. Analysis of risk factors for elbow dysplasia in giant breed dogs. 2016. Vet Comp Orthop Traumatol. 29(5):369-77.

49. Okonechnikov, Golosova, Fursov. Unipro UGENE: a unified bioinformáticas toolkit. 2012. Bioinformatics. 28:1166-1167

50. Ollier WER, Kennedy LJ, Thomson W. Dog MHC alleles containing the 
"human RA shared epitope" confer susceptibility to canine rheumatoid arthritis. 2001. Immunogenetics. 53: 669-73.

51. Ostrander E A, Kruglyak L. Unleashing the Canine Genome. 2000. Genome Res. 10: 1271-1274.

52. Pang JF, Kluetsch C, Zou XJ, Zhang AB, Luo LY, Angleby H. mtDNA data indicate a single origin for dogs south of Yangtze River, less than 16,300 years ago, from numerous wolves. 2009. Mol Biol Evol.26(12):2849-64.

53. Parker HG, Kim LV, Sutter NB, Carlson S, Lorentzen TD, Malek TB. Genetic structure of the purebred domestic dog. 2004. Science. 304(5674).

54. Parker HG, Shearin AL, Ostrander EA. Man's best friend becomes biology's best in show: Genome analyses in the domestic dog. 2010. Annu Rev Genet. 44:309-336.

55. Packer RM, Hendricks A, Tivers MS, Burn CC. Impact of facial conformation on canine health: brachycephalic obstructive airway syndrome. 2015. PLoS One 10, e0137496.

56. Patterson, D. Companion animal medicine in the age of medical genetics. 2000. J. Vet. Internal. Med. 14: 1-9.

57. Pedersen, P.B., Nielsen, C.B., Heegaard, S. Collie eye anomaly in blind Collie pups. 2004. Dansk Veterinaertidsskrift 87:27-29.

58. Pérez AA. La asociación lógica: corticoterapia y Ciclosporina A, una alternativa eficaz en el tratamiento de la queratitis superficial crónica 
inmunomediada .Tesis Doctoral. Facultad de Veterinaria . Universidad Complutense de Madrid. 2004.

59. Quinnell RJ, Kennedy LJ, Barnes A, Courtenay O, Dye C, Garcez LM, Shaw MA, Carter SD, Thomson W, Ollier WE. Susceptibility to visceral leishmaniasis in the domestic dog is associated with MHC class II polymorphism. 2003. Immunogenetics.55(1):23-28.

60. Rimbault M, Ostrander EA. So many doggone traits: mapping genetics of multiple phenotypes in the dog. 2012.Hum Mol Genet. 15;21(R1):R52-7.

61. Rugeles López MT, Montoya Guarin CJ. Inmunología. Una ciencia activa. 2da Edición. Universidad de Antioquia, 2009.

62. Sanger F, Nicklen S, Coulson AR. DNA sequencing with chain-terminating inhibitors. Proceedings of the National Academy of Sciences of the United States of America. 1977;74(12):5463-5467.

63. Schneider S, Roessli D, Excoffier L. Arlequin: a software for population genetics data analysis. 2000. Schneider S, Roessli D, Excoffier L. Arlequin: a software for population genetics data analysis User manual ver 2.000. Genetics and Biometry Lab, Dept. of Anthropology, University of Geneva; Geneva: 2000.

64. Singal D P, Qiu X. Polymorphism in the upstream regulatory regions and level of expression of HLA-DRB genes. 1994. Mol. Immunol. 31, 1117-1120.

65. Singal DP, Qiu X. Polymorphism in both $X$ and $Y$ motifs controls level of expression of HLA-DRB1 genes. 1996. Immunogenetics. 43, 50- 56. 
66. Skoglund P, Gotherstrom A, Jakobsson M. Estimation of population divergence times from non-overlapping genomic sequences: examples from dogs and wolves. 2011. Mol Biol Evol. 28(4):1505-17.

67. Summers JF, Diesel G, Asher L, McGreevy PD, Collins LM. Inherited defects in pedigree dogs. Part 2: disorders that are not related to breed standards. 2010. Vet J. 183(1):39-45.

68. Sutter NB, Eberle MA, Parker H, Pullar BJ, Kirkness EF, Kruglyak L, Ostrander E.A. Extensive and breed-specific linkage disequilibrium in Canis familiaris. 2004. Genome Research.14:2388-2396.

69. Takeshima SN, Matsumoto Y, Chen J, Yoshida T, Mukoyama H, Aida Y. Evidence for cattle major histocompatibility complex (BoLA) class II DQA1 gene heterozygote advantage against clinical mastitis caused by Streptococci and Escherichia species. 2008. Tissue Antigens. 72: 525-531.

70. Thursz MR, Thomas HC, Greenwood BM, Hill AV. Heterozygote advantage for HLA class-II type in hepatitis B virus infection. 1997. Nature Genetics. 17 (1): 11-12.

71. Ting JPY, Trowsdale J. Genetic control of MHC class II expression. 2002. Cell 109, 121: S21-33.

72. van Steenbeek FG, Hyt€onen $\uparrow$ MK, Leegwater PAJ, Lohi $\uparrow$ H. The canine era: the rise of a biomedical model. 2016. Animal Genetics 47: 519-527.

73. Wang G-D, Zhai W, Yang H-C. Out of southern East Asia: the natural history of domestic dogs across the world. 2016. Cell Research. 26(1):21-33. 
74. Wayne RK, Ostrander EA. Origin, genetic diversity, and genome structure of the domestic dog. 1999. Bioessays, 21: 247-257.

75. Wayne RK, Ostrander EA. Lessons learned from the dog genome. 2007.Trends in Genetics. 23, 557-67.

76. Whitley RD, Gilger BC. Cap: Diseases of the canine cornea and sclera. En Gelatt KN (Ed.) Veterinary Ophthalmology Ed. 3 ${ }^{\text {a }}$ Lippincott, Williams \& Willkins, 1999. 635-673.

77. Wilbe M, Jokinen P, Truvé K, Seppala EH, Karlsson EK, Biagi T, Hughes A, Bannasch D, Andersson G, Hansson-Hamlin H, Lohi H, Lindblad-Toh K. Genome-wide association mapping identifies multiple loci for a canine SLErelated disease complex. 2010. Nat Genet. 42(3): 250-4.

78. Wilcox B, Walkowicz C. The Atlas of Dog Breeds of the World Hardcover, 1995.

79. Williams DL. Major histocompatibility class II expression in the normal canine cornea and in canine chronic superficial keratitis. 2005.Veterinary Ophthalmology. 8, 6, 395-400.

80. Williams DL. Histological and immunohistochemical evaluation of canine chronic superficial keratitis. 1999. Res Vet Sci. 67(2):191-5.

81. Yoshida T, Furuta H, Kondo Y, Takeshima S, Aida Y, Kosugiyama M,Tomogane H. Association of the amino acid motifs of $B o L A-D R B 3$ alleles with mastitis pathogens in Japanese Holstein cows. 2009. Animal Science Journal. 5: 510-519. 
82. Yuzbasiyan-Gurkan V, Blanton SH, Cao Y, Ferguson P, Li J, Venta PJ, Brewer GJ. Linkage of a microsatellite marker to the canine copper toxicosis locus in Bedlington Terriers. 1997. American Journal of Veterinary Research. 58: $23-7$. 
7- ANEXOS 


\section{ANEXO 1. Planilla de examen ocular}

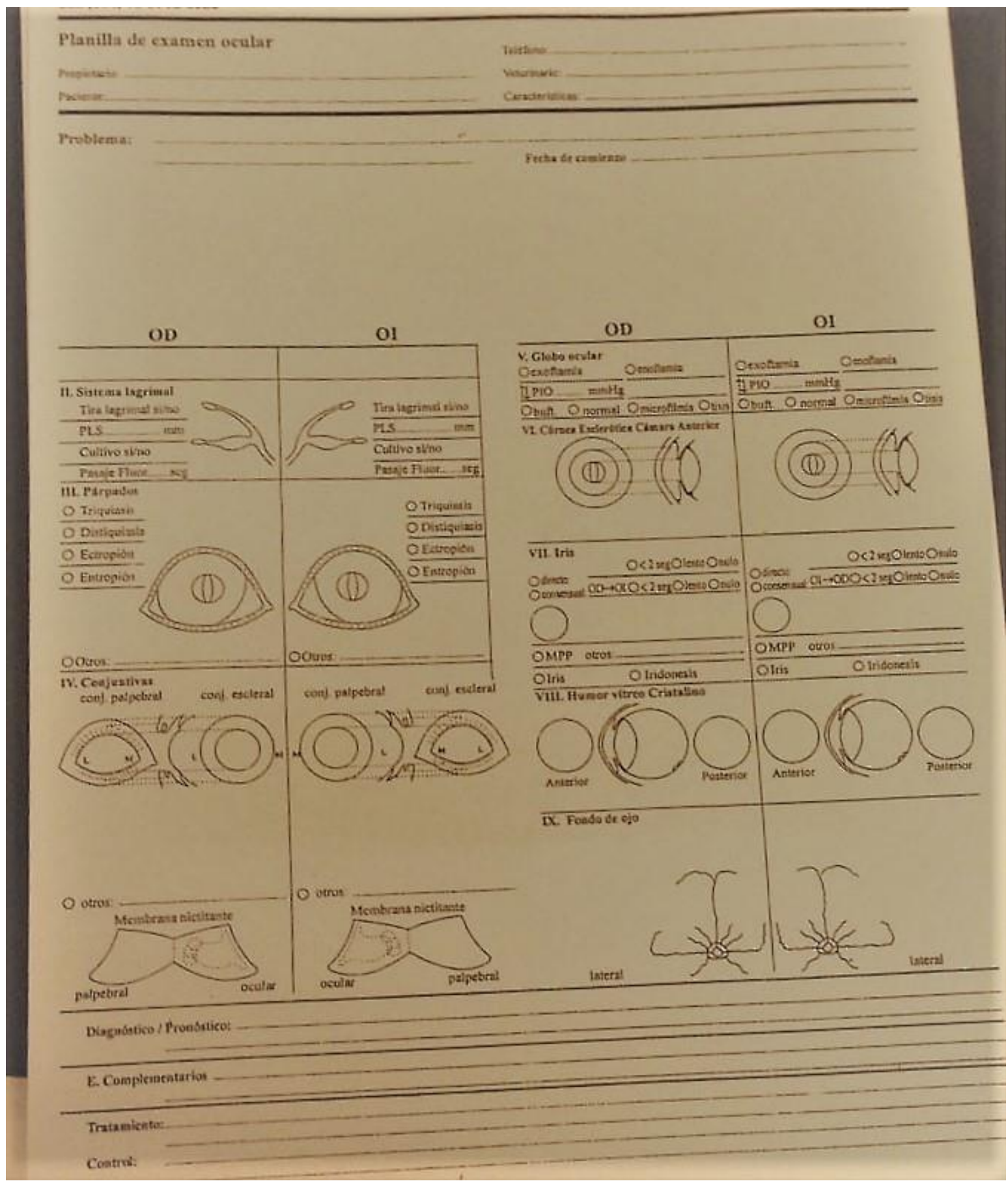


ANEXO 2. Modelo de consentimiento informado presentado a los propietarios de los animales muestreados.

\section{CONSENTIMIENTO INFORMADO}

En el día de la fecha: con DNI

Yo, ......

nro

Con domicilio en:

Calle: Nro: Localidad:

Pcia:. CP Teléfono.

Tras haber recibido información verbal clara y sencilla sobre el procedimiento. Autorizo voluntariamente a la extracción de muestra de sangre entera con EDTA/Hisopado bucal (tache lo que no corresponda) del paciente:

Nombre. Especie.

Sexo. Edad. Pelaje.

Nro. de Historia Clínica.

Para su utilización en (marcar con una $\mathrm{x}$ ):

...... Estudio de asociación genómica de la Queratitis Superficial Crónica en la raza Ovejero Alemán.

A realizarse en el IGEVET (Instituto de Genética Veterinaria), Facultad de Ciencias Veterinarias, Universidad Nacional de La Plata.

Firma:

Aclaración:

VETERINARIO
Firma:

Aclaración: PROPIETARIO 
ANEXO 3. Kit de purificación de ADN genómico Wizard $\square$ (Promega, Madison, WI, USA)

\begin{tabular}{|c|c|c|c|c|c|}
\hline \multirow{2}{*}{$\begin{array}{l}\text { Sample } \\
\text { Size }\end{array}$} & \multicolumn{2}{|c|}{$\begin{array}{l}\text { Lysis } \\
\text { Solution }\end{array}$} & \multirow{2}{*}{$\begin{array}{c}\text { Protein } \\
\text { Precipitation } \\
\text { Solution }\end{array}$} & \multirow[b]{2}{*}{ |sopropanol } & \multirow{2}{*}{$\begin{array}{c}\text { DNA } \\
\text { Rehydration } \\
\text { Solution }\end{array}$} \\
\hline & Cell & Nuclei & & & \\
\hline 300\% & 9004| & 300/ & 100\% & 300" & $100 \mu 1$ \\
\hline $1 \mathrm{~m} \mid$ & $3 m \mid$ & $1 \mathrm{~m} \mid$ & 330 | & $1 \mathrm{~m} \mid$ & 150"l \\
\hline $3 \mathrm{ml}$ & $9 \mathrm{ml}$ & $3 m \mid$ & $1 \mathrm{ml}$ & $3 \mathrm{ml}$ & 250ul \\
\hline $10 \mathrm{ml}$ & $30 \mathrm{ml}$ & $10 \mathrm{ml}$ & $3.3 \mathrm{ml}$ & $10 \mathrm{ml}$ & 8004 \\
\hline
\end{tabular}

Protocolo de extracción de ADN genómico a partir de sangre entera con EDTA, heparina o citrato.

1- Cargar $900 \mu \mathrm{l}$ de solución de lisis celular en tubos de 1,5 ml y agregar $300 \mu \mathrm{lde}$ sangre. Mezclar por inversión.

2- Incubar por 10 minutos a temperatura ambiente.

3- Centrifugar las muestras a 13000-16000 x g (velocidad máxima en microcentrífuga), 20 segundos.

4- Descartar sobrenadante y vortexear el pellet por 15 segundos.

5- Agregar $300 \mu 1$ de solución de lisis nuclear y se mezclar por inversión.

6- Agregar $100 \mu 1$ de solución de precipitación proteica y vortexear por 20 segundos.

7- Centrifugar las muestras según su volumen13000-16000 x g (velocidad máxima en micro-centrífuga), 3 minutos

8- Transferir el sobrenadante a un nuevo tubo de $1,5 \mathrm{ml}$ con $300 \mu 1$ isopropanol y mezclar suavemente hasta que aparezcan los " hilos" de ADN

9- Centrifugar las muestras según su volumen 13000-16000 x g (velocidad máxima en micro-centrífuga), 1 minuto.

10 - Descartar el sobrenadante y agregar $300 \mu 1$ etanol 70\%. 
11-Quitar el etanol y secar el pellet al aire por 10-15 minutos (no deben quedar restos de alcohol.

12- Rehidratar el ADN en $100 \mu$ de solución de rehidratación de ADN por 1 hora a $65^{\circ} \mathrm{C}$ u overnight a $37^{\circ} \mathrm{C}$.

13- Luego almacenar al ADN purificado a $-20^{\circ} \mathrm{C}$.

ANEXO 4. Protocolo de extracción orgánica de ADN total de sangre periférica

1- Alicuotar 500 ul de la muestra de sangre en tubos de 1,5 ml.

2- Lavar con 1000 ul de agua pura y centrifugar a 10000 g por 1 minuto.

3- Descartar el sobrenadante volcando suavemente el tubo y secar sobre papel la última gota. Repetir el lavado una vez mas o hasta que el pellet quede blanco.

4- Resuspender el pellet en 400 ul de Buffer de Extracción S (50mM de HCl-Tris, 25 mM de DTT, $2 \%$ de N-Laurylsarcosine)

5- Agregar $10 \mathrm{ul}$ de proteinasa $\mathrm{K}(10 \mathrm{mg} / \mathrm{ml})$ e incubar durante 3 horas a $55^{\circ} \mathrm{C}$ o toda la noche a $37^{\circ} \mathrm{C}$.

6- Llevar la muestra a temperatura ambiente y agregar 400 ul de cloroformo. Mezclar por inversión. Centrifugar a $10000 \mathrm{~g}$ por 1 minuto.

7- Transferir la fase acuosa, que contiene el ADN (superior), a un nuevo tubo y descartar la fase orgánica.

8- Repetir la extracción orgánica una vez más.

9- Transferir la fase acuosa a otro tubo y agregar $80 \mathrm{ul}$ de Acetato de Amonio 10M.

Centrifugar a $10000 \mathrm{~g}$ por 1 minuto. Transferir la fase acuosa a otro tubo y agregar $800 \mathrm{ul}$ de etanol $100 \%$ (preenfriado). Mezclar suavemente, precipitar durante 1 hora en hielo o en el freezer (se puede dejar toda la noche).

10- Centrifugar a 14000 g por 15 minutos. Luego descartar el sobrenadante volcando suavemente y secar la boca del tubo sobre papel.

11- Lavar el tubo con 250 ul de etanol $70 \%$ frio, centrifugar a 14000 g por 15 minutos y volver a descartar el sobrenadante.

12- Secar el pellet a $\mathrm{T}^{\circ}$ ambiente.

13- Agregar 100 - 200 ul de agua pura e incubar toda la noche en un baño a $37^{\circ} \mathrm{C}$ para hidratar el ADN. 
ANEXO 5.Cuantificación del ADN extraído y productos de PCR purificados.

\section{Protocolo del uso de NanoVue : Medición de concentración de ADN}

Espectrofotómetro NanoVue GE HealthCare

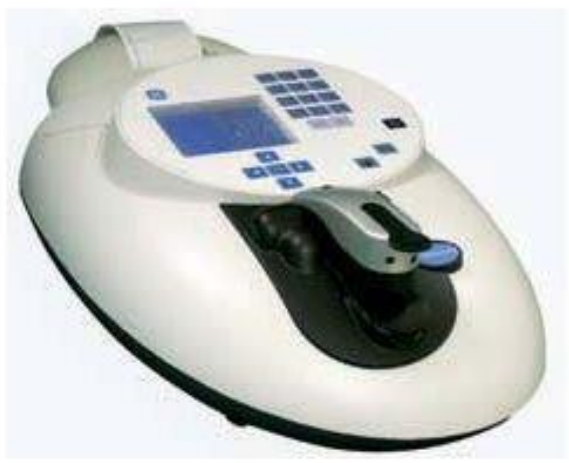

Panel de control

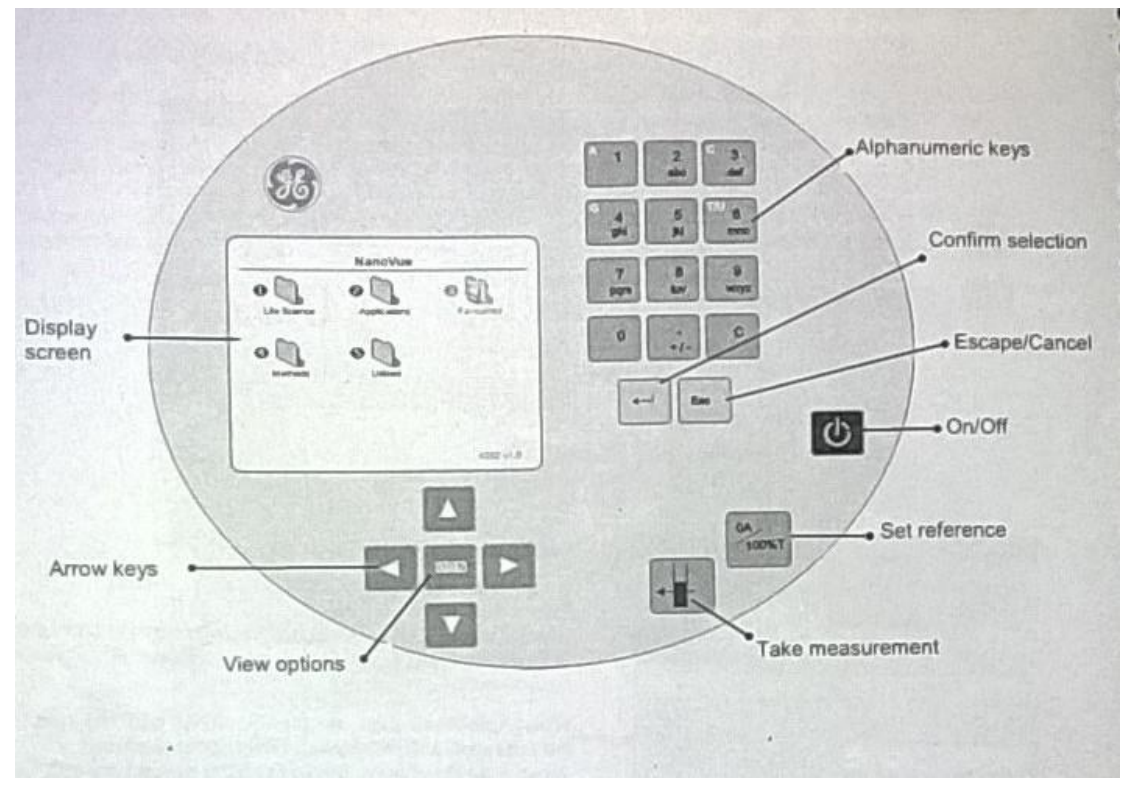

1) Encender el equipo utilizando la tecla color negra del panel de control (on/off).

2) En la pantalla se muestran los íconos de cinco carpetas con distintas funciones, utilizando la botonera alfanumérica, seleccionar la carpeta nro 1 con la leyenda "Life Science".

3) Seleccionar de las seis funciones que aparecen en la pantalla, la opción nro 1 con la leyenda DNA.

4) Confirmar la operación utilizando el botón “Confirm selection"ubicado debajo del teclado alfanumérico. 
5) Levantar la tapa que protege la placa de medición de muestra.

6) Para calibrar el espectrofotómetro con un blanco, colocar una gota de $3 \mu \mathrm{l}$ de agua destilada en el centro de la placa de medición, utilizando una micropipeta de $0-10 \mu 1$,

7) Bajar la tapa que protege la placa de medición.

8) Seleccionar del panel de control el botón "Set reference", para llevar el equipo a 0 absorbancia.

9) Aparecerá en la pantalla un cartel con la leyenda: "A second reference is required for comparison-Replace the reference and repeat".

10) Levantar la tapa, secar cuidadosamente con un papel absorbente estéril la zona donde estaba la gota y reemplazar con una nueva gota de agua destilada estéril.

11) Bajar la tapa y nuevamente pulsar nuevamente el botón "Set reference."

12) A continuación en la pantalla, todos los parámetros de medición se colocaran en cero.

13) Levantar la tapa, limpiar la placa de medición el agua utilizada anteriormente.

14) Colocar una gota de $3 \mu 1$ de la muestra problema en el centro de la placa de medición.

15) Pulsar el botón de tomar medida "Take measurement".

16) La concentración $[\mathrm{ng} / \mu \mathrm{l}]$ aparecerá en el recuadro "Concentration" y la relación de absorbancias (A260/A280) en el recuadro correspondiente (Indicador de calidad de ADN, el valor debe estar entre 1,7 y 2).

17) Una vez finalizada la utilización del equipo, apagar utilizando la misma tecla de encendido (on/off) y luego desconectarlo de la red eléctrica.

ANEXO 6 . Chequeo de productos de PCR en geles de poliacrilamida 6\%.

Preparación de geles de poliacrilamida $6 \%$

Agua destilada...................... $9 \mathrm{ml}$

TBE 5X.......................... $3 \mathrm{ml}$

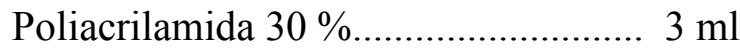

APS............................ $150 \mu 1$

TEMED.......................... $15 \mu 1$

1. Limpiar los vidrios con alcohol $70 \%$ para desengrasarlos.

2. Colocar los separadores $(0,375 \mathrm{~mm})$ sobre el vidrio entero y apoyar encima, con mucho cuidado, el vidrio calado. Sujetar con ganchos o clips.

3. Agregar el APS y luego el TEMED a la mezcla de poliacrilamida, mezclar bien y proceder (desde el extremo calado) a cargar el gel con una pipeta de vidrio, evitando que se formen burbujas de aire.

4. Una vez lleno el molde con el gel, colocar el peine con cuidado.

5. Esperar que polimerice y montar en la cuba electroforética con TBE 1X. No dejar el gel polimerizado mucho tiempo sin montar para evitar la deshidratación.

6. Sembrar las muestras y correr a 170 voltios durante el tiempo necesario (30 minutos aproximadamente).

TBE 5X:

$54 \mathrm{~g}$. de Tris base. 
$27,5 \mathrm{~g}$. de Ácido Bórico.

$20 \mathrm{ml}$ de EDTA 0.5M ( $\mathrm{pH}=8)$.

Completar hasta $1000 \mathrm{ml}$ con agua destilada.

\section{Preparación de las muestras para su siembra}

La muestra se siembra en el gel con colorante DYE, permitiendo así su visualización durante la corrida electroforética.

Se toman $3 \mu 1$ del ADN genómico y se le agregan $1 \mu 1$ de DYE, los $4 \mu 1$ resultantes se colocan en los pocillos del gel.

La corrida electroforética se realiza a 170 voltios durante 1 hora y cuarto.

\section{Colorante DYE:}

$0.025 \mathrm{~g} . . . \ldots \ldots \ldots \ldots \ldots \ldots \ldots \ldots$ de Bromophenol Blue.

$4 \mathrm{~g} \ldots \ldots \ldots \ldots \ldots \ldots \ldots \ldots \ldots \ldots$ de sacarosa.

Completar hasta un volumen final de $100 \mathrm{ml}$ con agua destilada.

\section{Revelado de los geles}

1. Se colocan $50 \mu 1$ de Bromuro de etidio en $500 \mathrm{ml}$ de $\mathrm{H} 20$ destilada.

2. Sumergir el gel en la solución por 10 minutos.

3. Revelar bajo luz UV.

ANEXO 7.Purificación de las reacciones de PCR por precipitación con polietilenglicol (PEG)

Este protocolo está ajustado para reacciones de PCR de $50 \mu 1$. Si el volumen de la PCR es diferente, modificar la escala manteniendo las proporciones.

1. Correr $5 \mu 1$ de la PCR en un gel de agarosa para verificar la amplificación.

2. Al resto de la reacción de PCR agregarle $50 \mu 1$ de una solución de 20\% PEG -2.5 M $\mathrm{NaCl}$ y mezclar bien.

3. Incubar a $37^{\circ} \mathrm{C}$ por 15 minutos.

4. Centrifugar a alta velocidad $(\sim 15.000 \mathrm{x}$ g) durante 15 minutos a temperatura ambiente.

5. Retirar el sobrenadante con pipeta y descartarlo. El pellet es incoloro y queda adherido a la pared del tubo.

6. Agregar $125 \mu 1$ de etanol $70 \%$. Si se agrega el etanol en el fondo del tubo, centrifugar 2 minutos. Si se agrega el etanol suavemente por la pared del tubo, dejar reposar un 
minuto. Eliminar el sobrenadante y descartar. Eliminar la mayor cantidad posible del etanol.

7. Secar el pellet a $37^{\circ} \mathrm{C}$ durante $10-15$ minutos. Asegurarse de que no queden restos de etanol y que el pellet esté seco. Un exceso en el secado del pellet dificulta la resuspensión.

8. Disolver el producto de PCR en $20 \mu 1$ de agua bidestilada estéril. Resuspender completamente el pellet (con pipeta o vortex). Ayuda incubar por unos minutos a temperatura ambiente o a $37^{\circ} \mathrm{C}$.

9. Correr de 2 a $4 \mu \mathrm{l}$ en un gel de agarosa durante 10 minutos para tener una idea aproximada del porcentaje de recuperación. Simultáneamente sembrar 20 y 100 ng de un standard de DNA.

\section{Solución 20\% PEG - 2,5 M NaCl}

Para $50 \mathrm{ml}$ mezclar:

1) 10.0 g polietilenglicol 8000 (funciona igualmente con el PEG 6000 u 8000)

$7.3 \mathrm{~g}$ de $\mathrm{NaCl}$

2) Agregar $45 \mathrm{ml}$ de agua bidestilada.

3) Agitar y dejar disolver el PEG durante al menos 20 minutos. Se puede colocar la solución en un agitador a $37^{\circ} \mathrm{C}$.

3) Una vez disuelto el PEG (la solución se vuele incolora), completar el volumen hasta $50 \mathrm{ml}$ con agua bidestilada.

4) Conservar a temperatura ambiente.

\section{ANEXO 8. Secuenciación}

Se utilizó un secuenciador automático MEGABACE 1000. Que utiliza una mezcla de nucleótidos sin marcar y dideoxinucleótidos marcados fluorescentemente con distintos colores. La secuenciación se lleva a cabo en una sola reacción. Los fragmentos obtenidos en la reacción se separan por electroforésis en un capilar de poliacrilamida y el color asociado a cada uno de ellos se detecta utilizando un rayo láser. La secuencia de colores registrada por el detector a lo largo de la corrida es indicativa de la secuencia 
de bases que componen al fragmento, y es informada al usuario a través de un computador. (Ver figura en ANEXO 9)

\section{Protocolo de realización de las reacciones de secuenciación}

Para $10 \mu 1$ de volumen final:
ADN (200 ng) + agua...................... $5 \mu \mathrm{l}$
$\operatorname{primer}(5 \mathrm{uM}=5 \mathrm{pmol} / \mathrm{ul}) \ldots \ldots \ldots \ldots \ldots \ldots \ldots . .1 \mu \mathrm{l}$
premix (DYEnamic ET Dye Terminator)..... $4 \mu 1$
volumen final...............................10 101

Programa de PCR poco riguroso: 40 ciclos de 20 segundos a $95^{\circ} \mathrm{C}, 15$ segundos a $50^{\circ} \mathrm{C}$ y 1 minuto a $60^{\circ} \mathrm{C}$.

Purificar las reacciones para eliminar los cebadores y los nucleótidos fluorescentes no incorporados, para ello se realiza una precipitación con acetato de amonio y etanol de acuerdo al siguiente protocolo.

Reacción de secuencia................ $10 \mu \mathrm{l}$

Acetato de amonio $7.5 \mathrm{M} \ldots \ldots \ldots \ldots \ldots . . .1 \mu \mathrm{l}$

Etanol absoluto........................30 $\mu 1$

1. Centrifugar a $15.000 \mathrm{rpm}$ durante 15 minutos.

2. Descartar el sobrenadante.

3. Lavar con $100 \mu \mathrm{l}$ de etanol 70\%, agregando el alcohol con suavidad para no despegar el pellet.

4. Centrifugar a $15.000 \mathrm{rpm}$ durante 2 minutos y eliminar tanto etanol como sea posible (si quedaran gotas en las paredes, centrifugar brevemente y eliminarlas con la pipeta).

Esto es importante ya que los restos de etanol producen artefactos en la corrida del secuenciador (dye blobs).

5. Secar el etanol a $37^{\circ} \mathrm{C}$ durante aproximadamente 10 minutos. No secar excesivamente (dificulta la resuspensión).

6. Disolver el pellet en $10 \mu 1$ de MegaBACE Loading Solution vortexeando vigorosamente durante 20-30 segundos para asegurar una resuspensión completa. 
ANEXO 9. Esquema de un proceso de secuenciación.

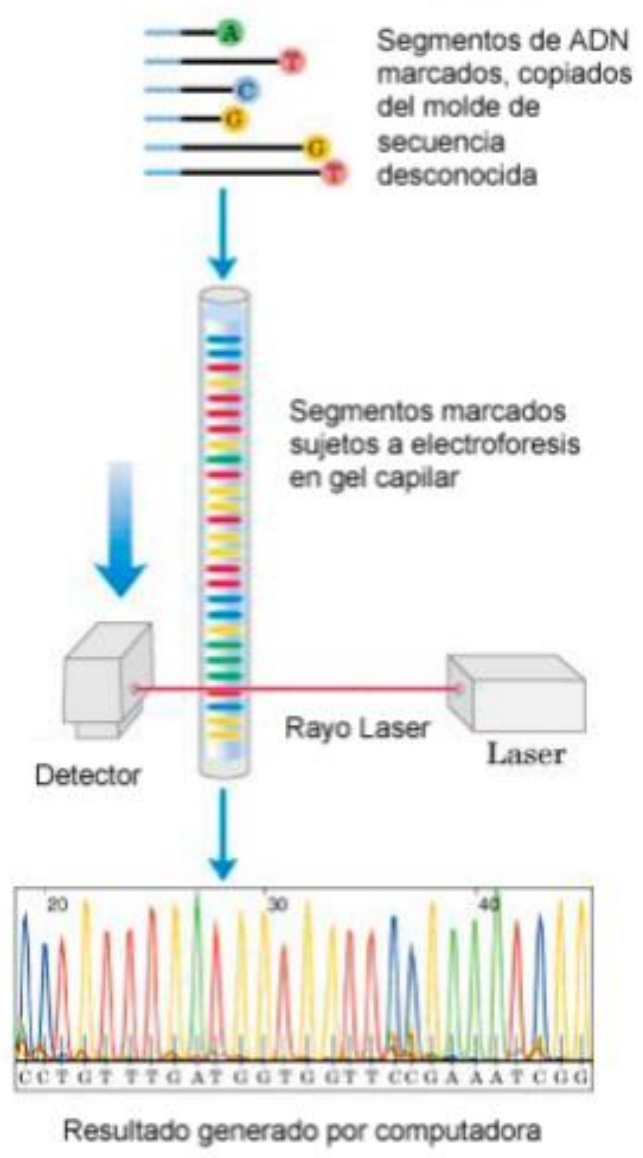


ANEXO 10. Protocolos de amplificación:

Secuenciación (volumen final: $25 \mu \mathrm{l}$ )

Agua Destilada $\quad \operatorname{csp}$

$\begin{array}{lrc}\text { Buffer } & 20 & \mathrm{mM} \\ \text { dNTP's } & 200 & \mu \mathrm{M} \\ \mathrm{MgCl}_{2} & 1,5 & \mathrm{mM} \\ \text { Primer - F }(5 \mu \mathrm{M}) & 0,4 & \mu \mathrm{M} \\ \text { Primer - R }(5 \mu \mathrm{M}) & 0,4 & \mu \mathrm{M} \\ \text { Taq. Polimerasa } & 0,5 \mathrm{UI} \\ \text { ADN } & 25-50 \mathrm{ng}\end{array}$

ANEXO 11.

a) Geles de poliacrilamida 6\%. Chequeo de productos de PCR (Microsatélites). 1)2)3)4) Muestras problema. (+) Positivo. (-) Negativo.

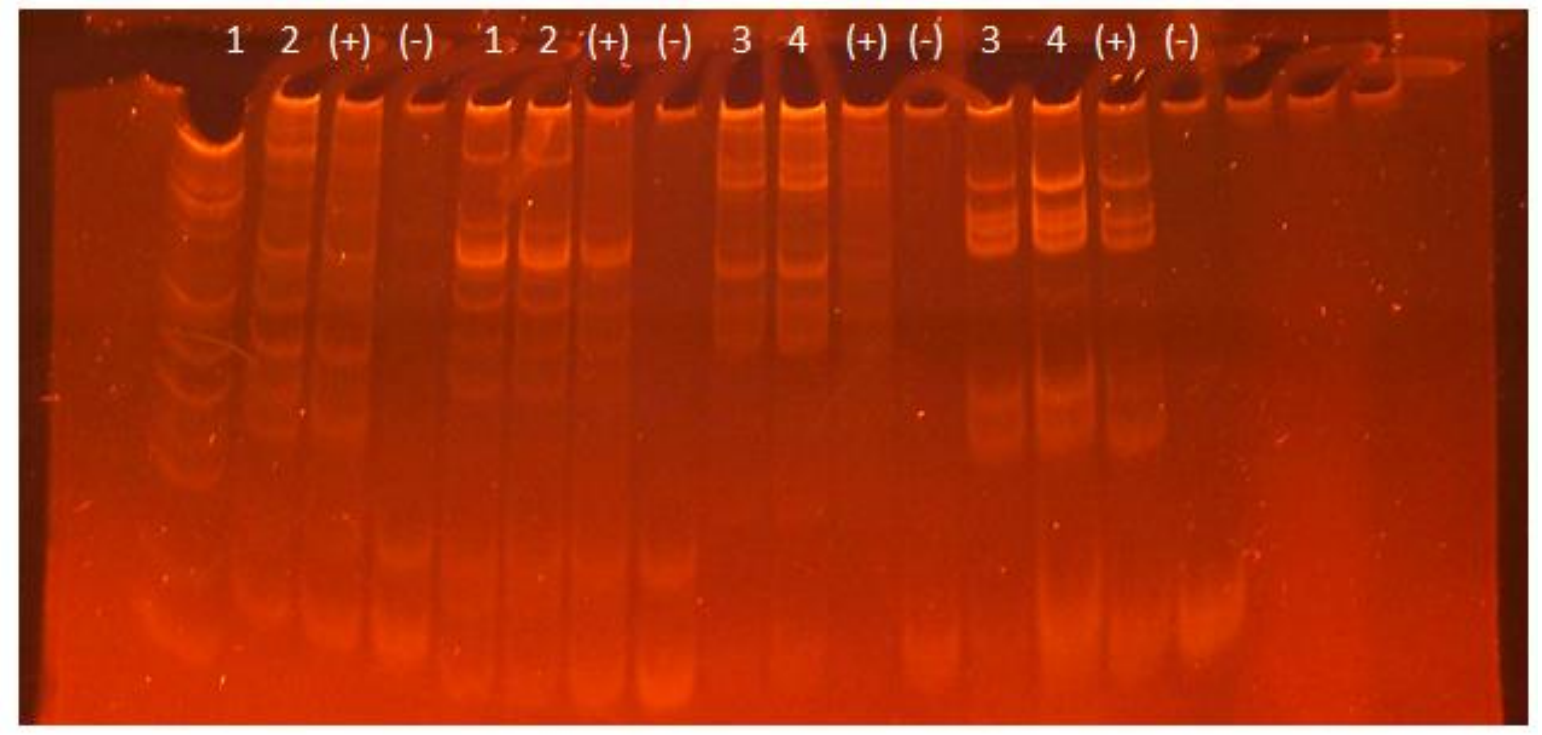




\section{ANEXO 11 b) Cromatogramas de los microsatélites. 1)FH2054}
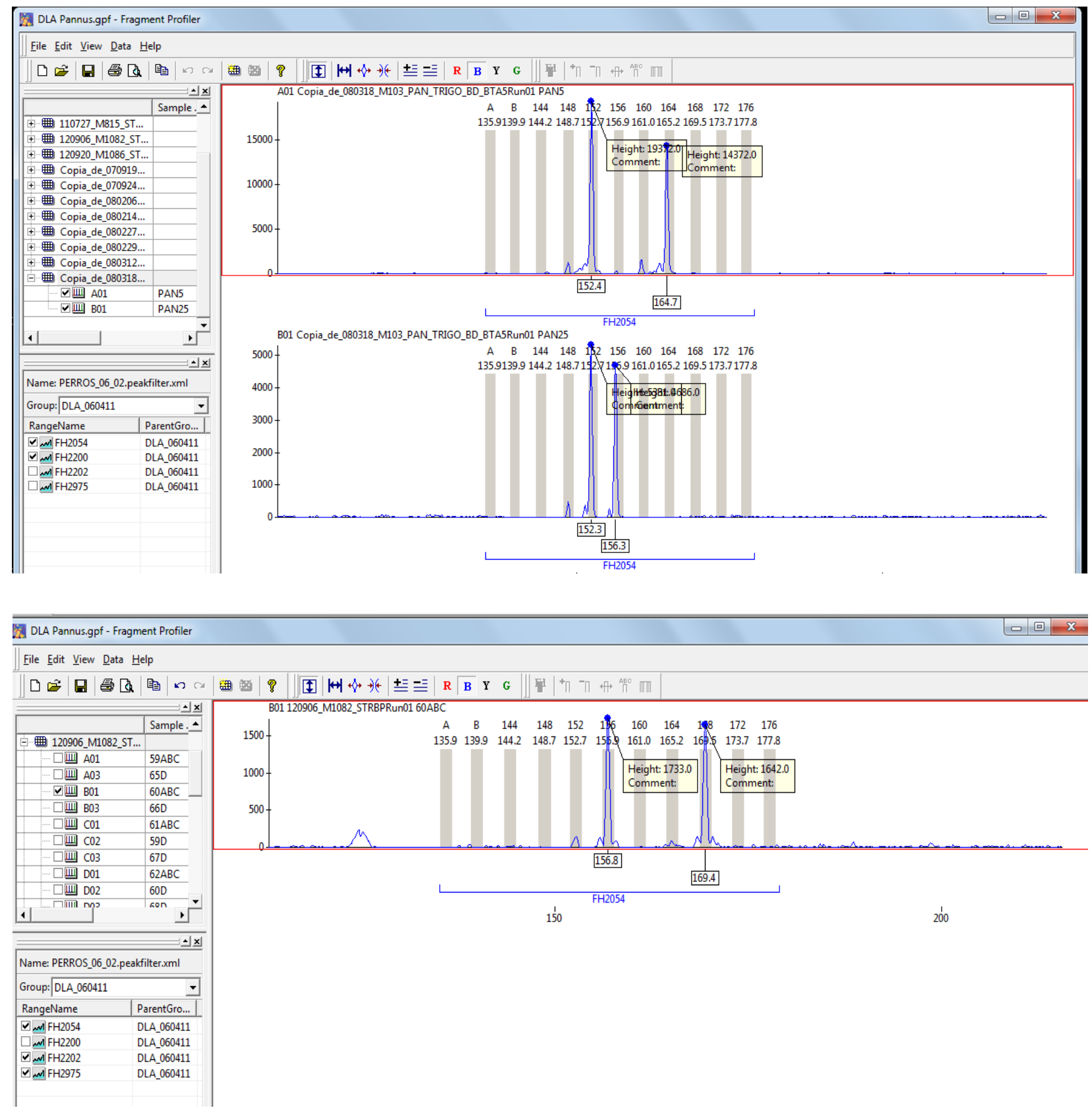


\section{2) FH2202}
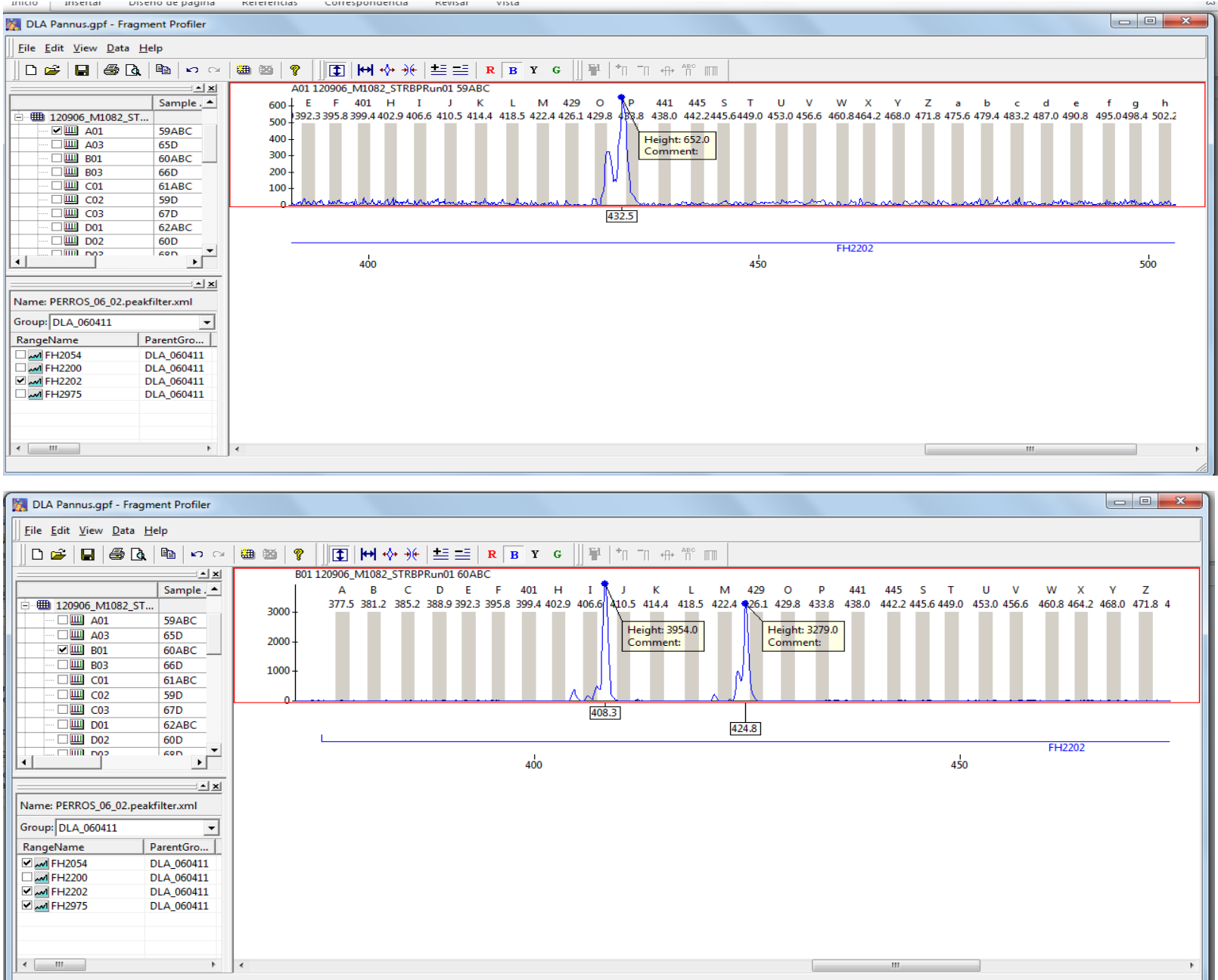


\section{3) FH2975}

DLA Pannus.gpf - Fragment Profiler

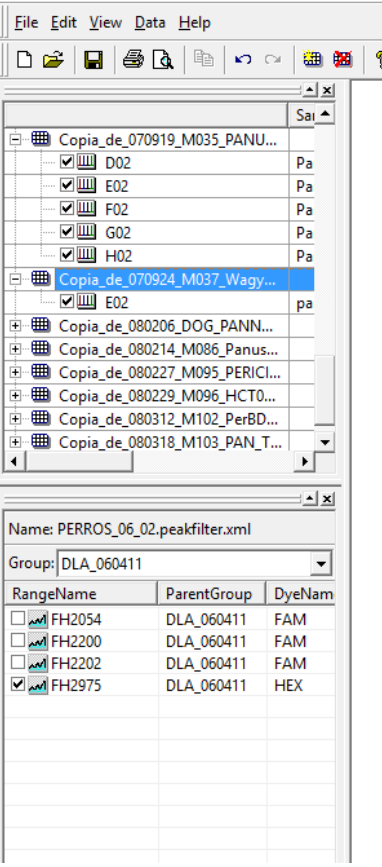

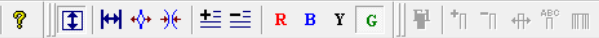

E02 Copia_de_070919_M035_PANUS_DonB_ArecoRun01 Pannus3

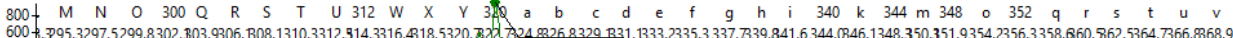

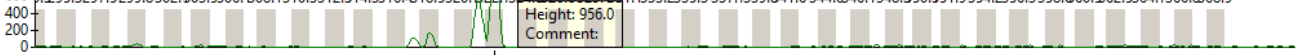
322.7

F02 Copia_de_070919_M035_PANUS_DonB_ArecoRun01 Pannus6

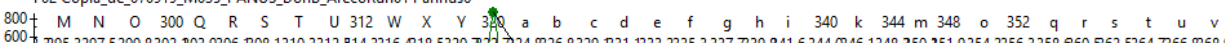

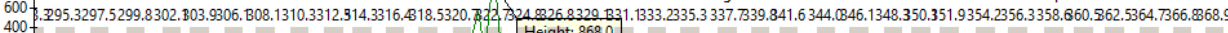
${ }_{0}^{200} \mathrm{Z}$ 322.7

G02 Copiade 070919 M035 PANUS_DonB_ArecoRun01 Pan2

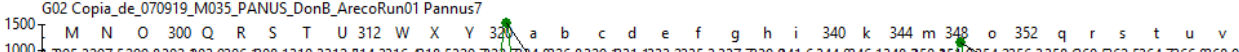

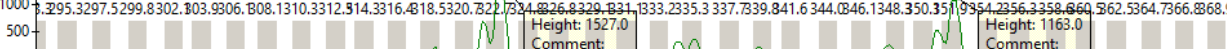

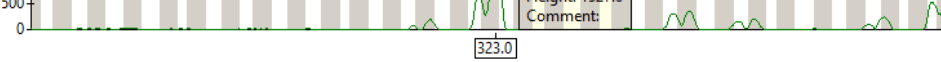

H02 Copia_de_070919_M035_PANUS_DonB_ArecoRun01 Pannus8

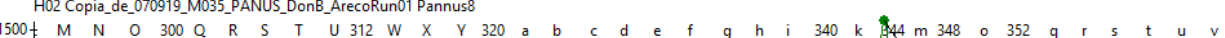

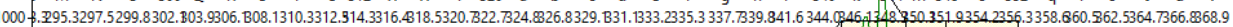

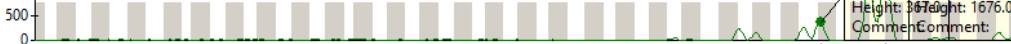

343.6

347.7

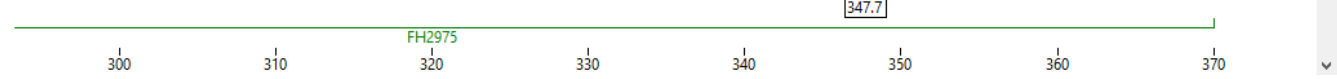


ANEXO 12. Alineamiento de las secuencias reportadas para el exón 2 de los genes DLA de clase II. Base de datos IPD-MHC

\section{a) DLA-DRB1}

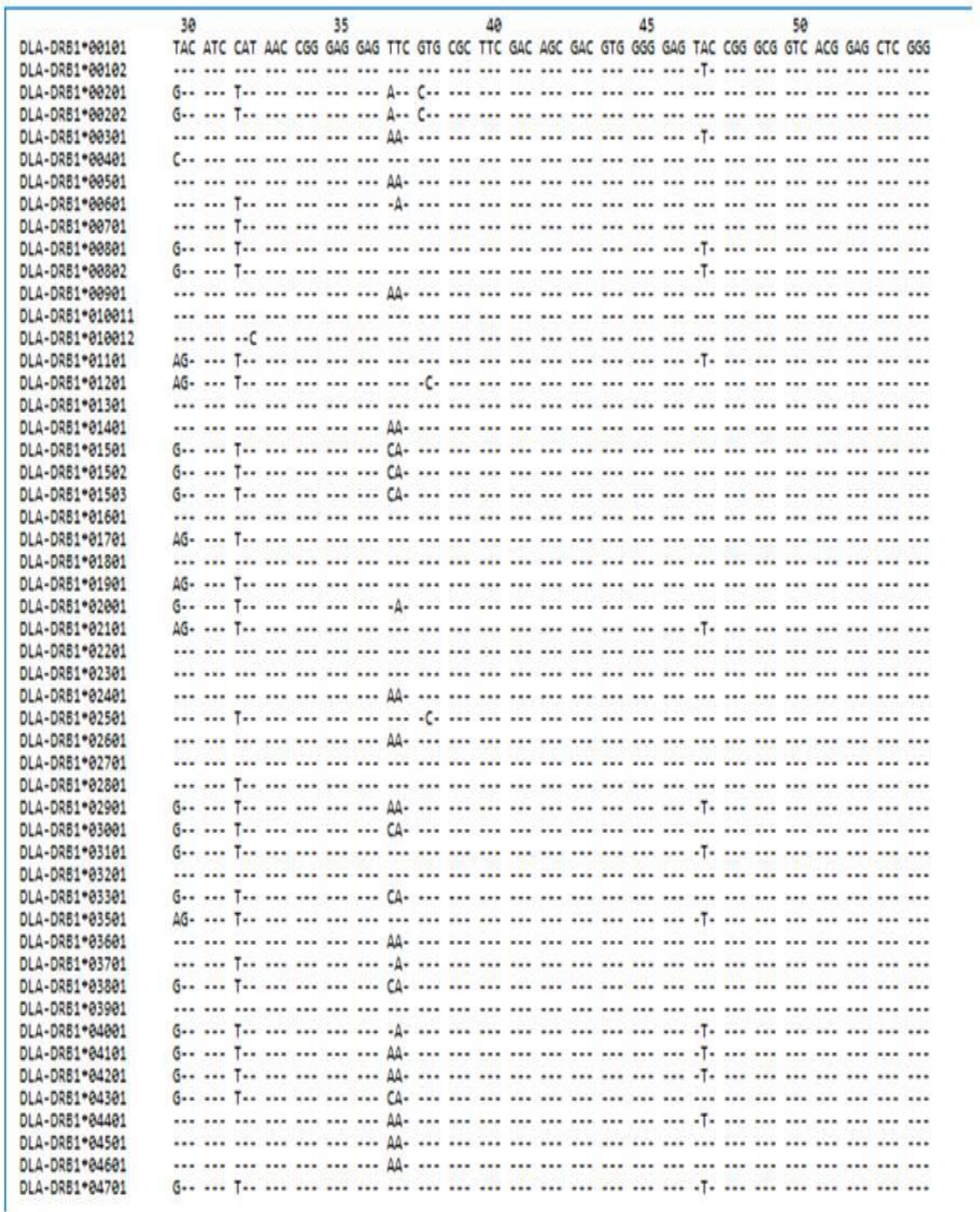


DLA-DRB1 *0101 OLA.DRB1 •0102 DLA-DRB1 + 02201 OLA-DRB1 - 09202 DLA-DRB1 * CA3O1 DLA-DRB1 • QQ4O1 DLA-DRB1-09501 OLA-DRB1・Q9601 DLA-DRB1 *09701 DLA-DRB1・QBBOI DLA-DRB1 - 09802 OLA-DRB1- 09991 OLA-DRB1-010911 OLA-DRB1-012912 OLA-DRB1*O1101 DLA-DRB1*01201 DLA-DRB1-01301 OLA-DRB1*01401 DLA-DRE1・01501 OLA-DRB1・01502 OLA-DRB1-01503 DLA-DRB1·01601 DLA-DRB1-91791 DLA-DRB1 •01801 DLA-DRB1-O19O1 OLA-DRB1 •02001 DLA-DRE1:02101 OLA-DRB1・02201 OLA-DRB1-02301 OLA-DRB1-02401 DLA-DRB1-92501 DLA-DRB1 -92601 DLA-DRB1:02701 OLA-DRB1-02BO1 OLA-DRB1-02901 OLA-DRB1-03091 OLA-DRB1-O3101 DLA-DRE1-03201 DLA-DRB1-03391 OLA-DRB1-03501 DLA-DRB1*03601 DLA-DRB1*03701 DLA-DRB1•03801 OLA-DRB1・03991 DLA-DRE1 - Q4Q91 OLA-DRB1-Q4101 OLA-DRB1-04201 DLA-DRB1*QA3O1 OLA.DRB1.QA4O1 DLA-DRB1・QA501 DLA-DRB1*QA691 OLA-DRB1・04701
$55 \quad 60 \quad 78 \quad 75$

COS CCC GTC OCT GAO TCC TGO AAC GOS CAO AAG GAG ATC TTO GAG CAG CAO COS GCA ACO GTO GAC ACC TAC TGC

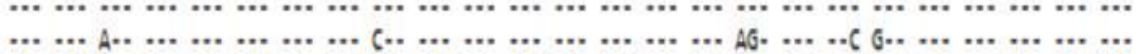

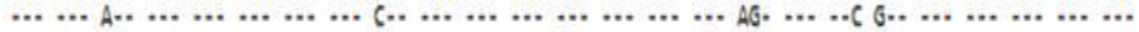

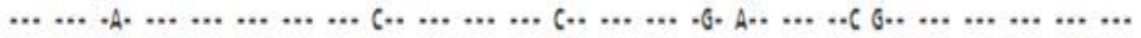

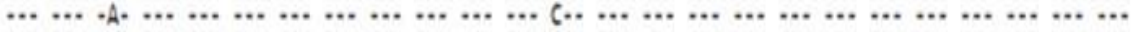

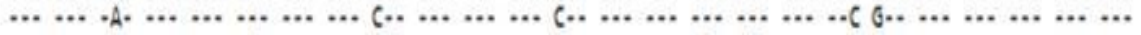

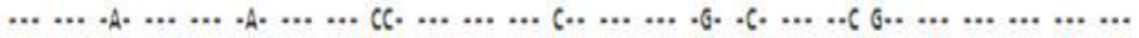

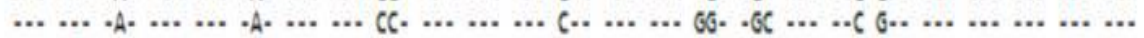

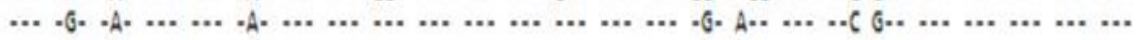

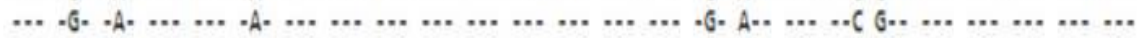

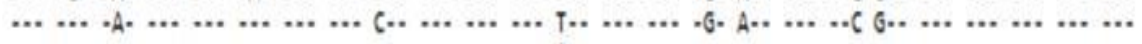

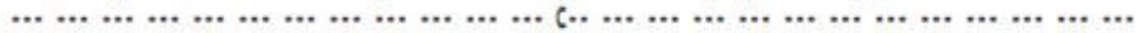

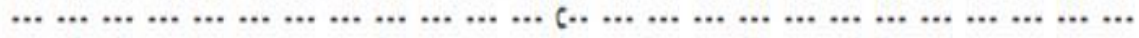

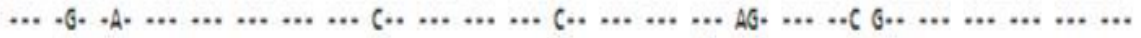

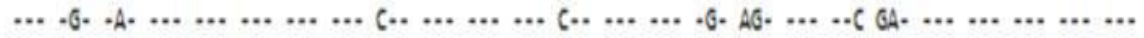

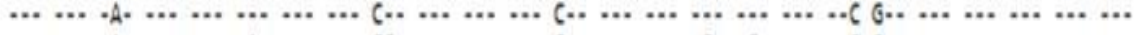

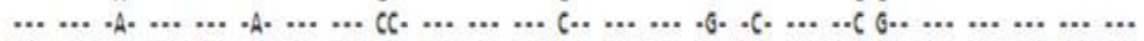

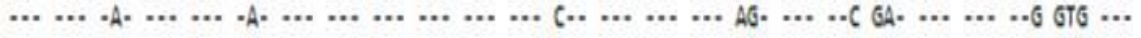

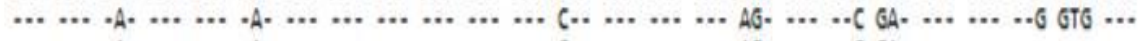
$\ldots \ldots$........................... C...................

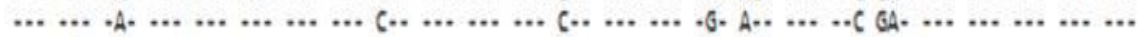

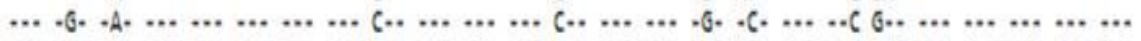

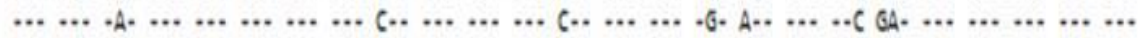

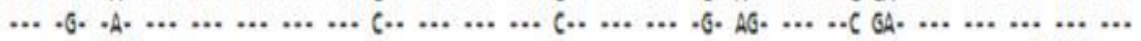

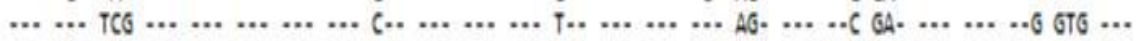

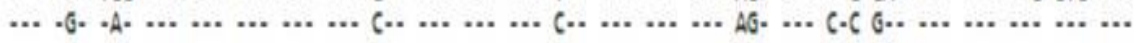

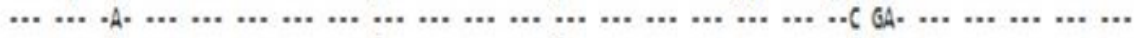

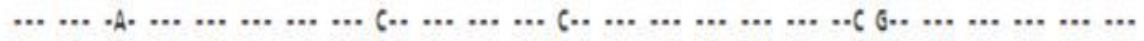

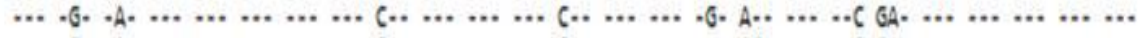

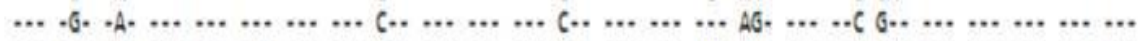

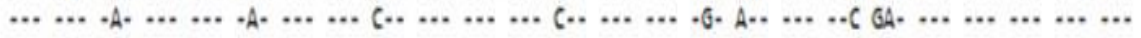

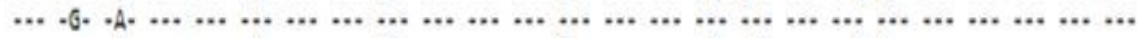

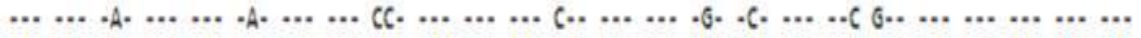
$\ldots$. . G. A. ................................. . G. A.. ... .. G G..............

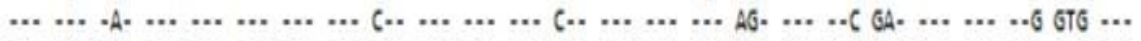

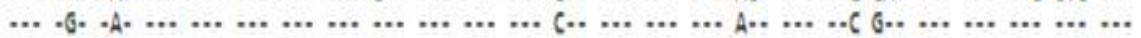

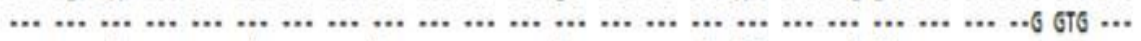

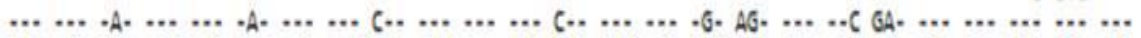

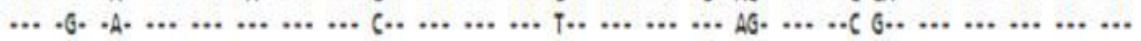

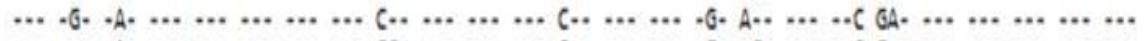

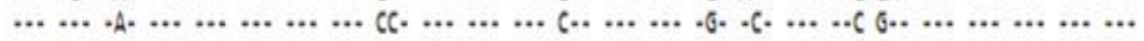

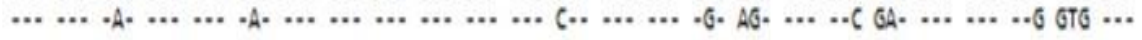

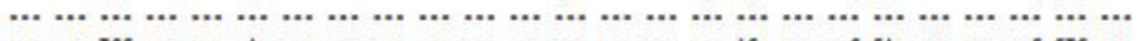

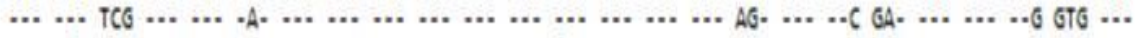

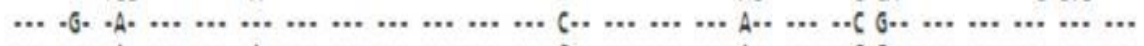

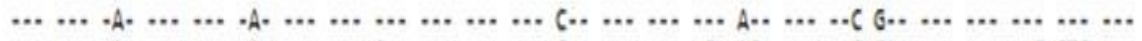

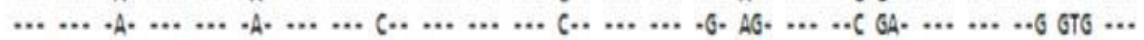

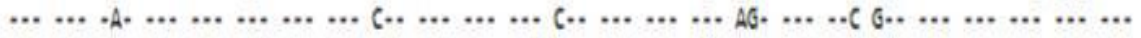

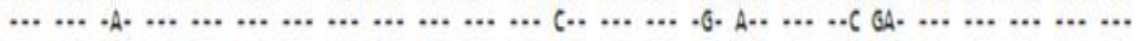

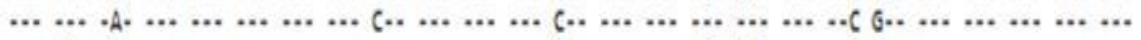

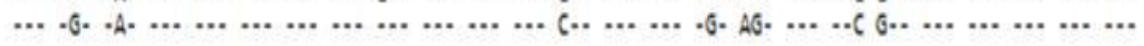


DLA-DRE1・00101 DLA-DRB1 - 60102 DLA-DRB1 -69201 OLA-DRB1 • 69202 DLA-DRB1-093e1 DLA-DRB1-0Q491 OLA-DRB1 • 09501 DLA-DRB1 • 69601 DLA-DRB1 - 69701 DLA-DRB1 *09801 OLA-DRB1 • 69892 DLA-DRB1 *09991 DLA-DRB1 • 10911 DLA-DRB1 •010912 DLA-DRB1*01101 DLA-DRB1 •01201 DLA-DRB1-01301 DLA-DRB1 •01401 OLA-DRB1 •015e1 DLA-DRB1 • 01502 DLA-DRB1・01503 DLA-DRE1 • 01601 DLA-DRB1 • 01701 DLA-DRE1・91801 DLA-DRB1 *01901 DLA-DRE1 • 92691 DLA-DRB1 • 22101 DLA-DRB1•02201 DLA-DRB1 • 22301 DLA-DRB1 • 02401 DLA-DRB1•02501 DLA-DRB1-02601 DLA-DRB1 - 22701 DLA-DRB1 •02801 DLA-DRB1 •02901 DLA-DRB1 •03e91 DLA-DRB1-03101 DLA-DRB1 -03201 OLA-DRB1 • 03301 DLA-DRB1 • 03501 DLA-DRB1 •03601 DLA-DRB1-03701 DLA-DRB1・03801 DLA-DRB1・03901 DLA-DRE1 •Q4901 OLA-DRB1+Q4101 OLA-DRB1・B4201 DLA-DRB1*Q4301 DLA-DRB1・84401 DLA-DRB1・Q4501 DLA-DRB1-Q4601 DLA-DRB1・Q4701
$8 e$

85

90

95

AGA CAC AAC TAC GGG GTS ATT GAG AGC TTC ACG GTG CAG CGS COA G

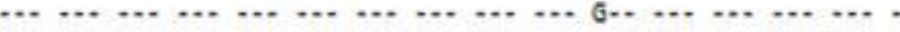

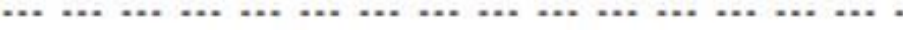

[..

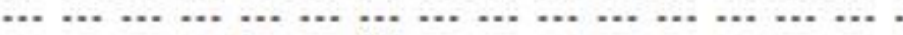

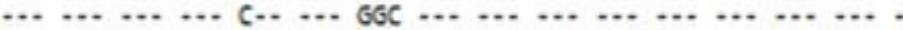

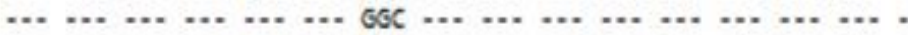

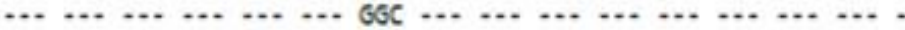

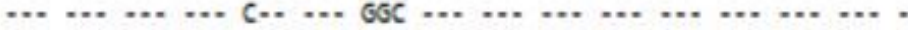

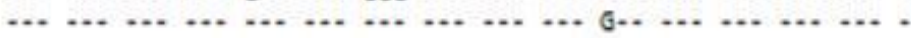

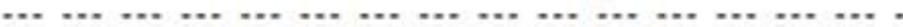

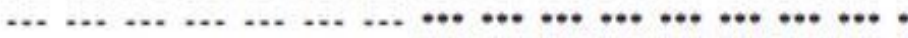

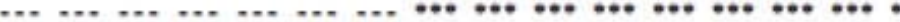

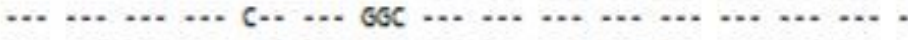

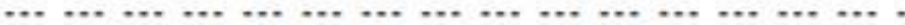

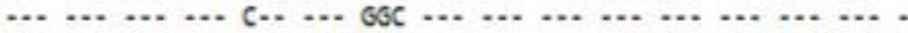

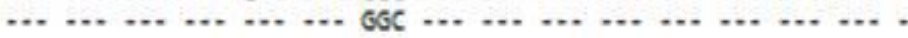

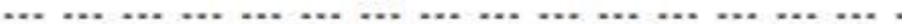

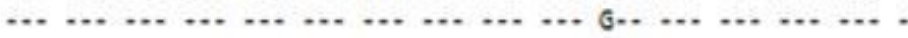

[...

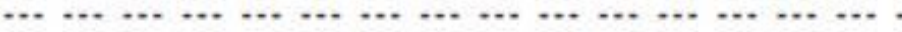

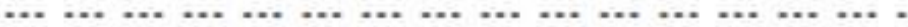

[..

[..

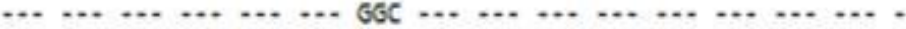

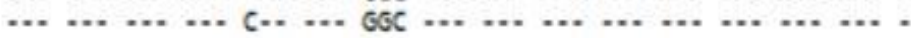

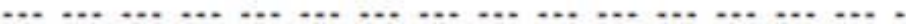

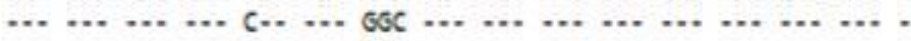

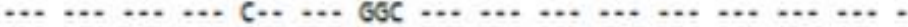

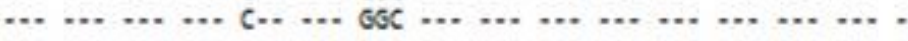

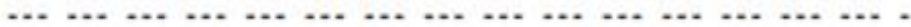

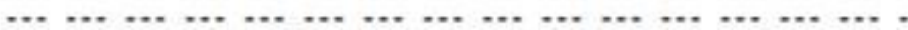

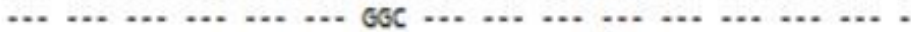

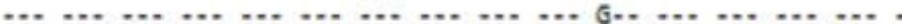

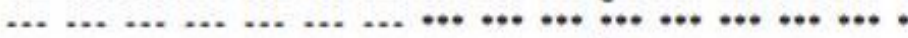

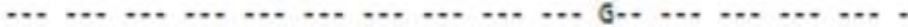

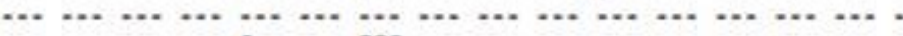

...

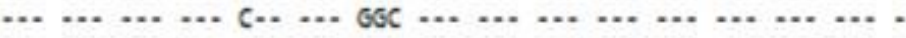

[..

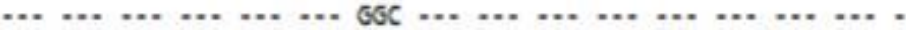

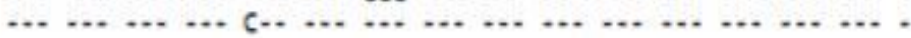

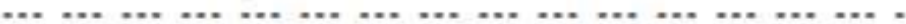

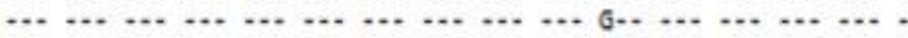

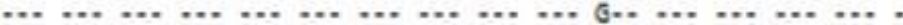

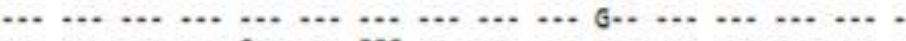

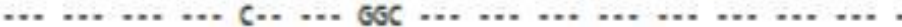

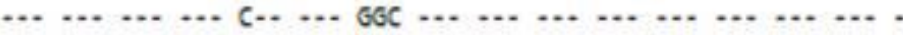

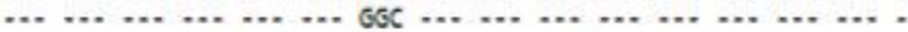

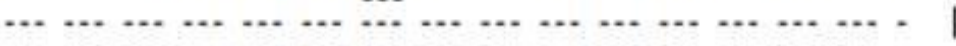

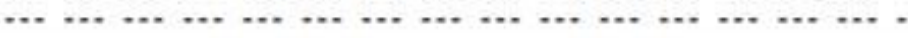




\section{b) DLA-DQA1.}

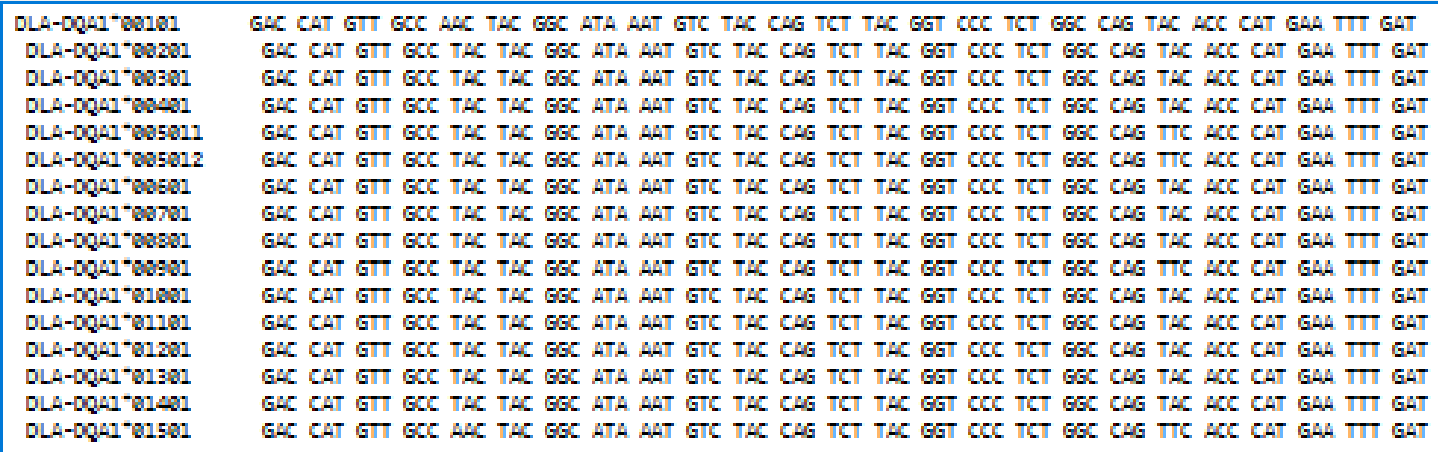

DLA-DQ41-00102 DLA-DQA1-00201 OLA-DQA1-00301 OLA-0QA1"00401 DLA-DQA1"00501] OLA-DQA1-005012 OLA-DQA1"00601 DLA-DQA1"00701 DLA-DQA1-00601 DLA-DQA1"00901 OLA-DQA1"01001 DLA-DQA1"01101 DLA-DQA1'01201 OLA-0QA1'01301 OLA-DQA1"01401 DLA-DQA1"01501

OLA-0QA1'00101 OLA-DQA1'00201 DLA-DQA1'00302 DLA-DQA1'0040 OLA-DQA1'005011 DLA-DQA1'005012 DLA-DQA1"0050? DLA-0Q41-00701 DLA-DQA1'00BO1 DLA-DQA1'00801 DLA-DQA1'01001 OLA-0QA1'01101 DLA-DQA1'01201 DLA-DQA1"01301 OLA-DQA1"01401 DLA-DQA1'01501

OLA-DQA1"00101 OLA-DQA1'00201 OLA-DQA1'00301 DLA-DQA1"00401 DLA-DQA1'005011 DLA-0QA1'005012 DLA-DQA1'00601 DLA-DQA1'00701 DLA-DQA1'00BO1 OLA-DQA1'00901 OLA-0QA1"01001 DLA-DQA1'01101 DLA-DQA1'01201 OLA-0QA1'01301 OLA-DQA1"01401 $\Delta 0$ 45 50 55 GGC GAT GAG GAG TTC TAC GTG GAC CTG GLG ARG ALG GAA ACT GTC TGG CGG CTG CCT GTG TTT LGC ACA TTT LGA GSC GAT GAG GAG TTC TAC GTG GAC CTG GAG AAG ALG GAA ACT GTC TGG CGG CTG CCT GTG TTा AGC ACA TTा ACA GSC GAT GAG GAG TTC TAC GTG GAC CTG GAG AAG AAG GAA ACT GTC TGG CGG CTG CCT GTG TTT AGC ACA TTा ACA GGC GAT GAG GAG TTC TAC GTG GAC CTG GAG ARG ALG GAA ACT GTC TGG CGG CTG CCT GTG TTT AGC ACA TTT ACA GBC GAT GLG GLG TTC TAC GTG GLC CTG GLG ALG ARG GAA ACT GTC TGG CGG CTG CCT GTG TTT LGC ACA TTा ACA GGC GAT GAG GAG TTC TAC GTG GAC CTG GAG ARG ARG GAA ACT GTC TGG CGG CTG CCT GTG TTा AGC ACA TTा ACA GGC GAT GAG GAG TTC TAC GTG GAC CTG GLG AAG ALG GAA ACT GTC TGG CGG CTG CCT GTG TTा AGC ACA TTा AGA GSC GAT GAG GAG TTC TAC GTG GAC CTG GAG ARG ALG GAA ACT GTC TGG CGG CTG CCT GTG TTा AGC ACA TIT ACA GSC GAT GAG GLG TTC TAC GTG GAC CTG GAG ARG ALG GAA ACT GTC TGG CGG CTG CCT GTG TTा AGC ACA TTा ACA GGC GAT GAG GAG TTC TAK GTG GAC CTG GLG ALG AAG GAA ACT GTC TGG CGG CTG CCT GTG TTT AGC ACA TTT AGA GSC GAT GAG GAG TTC TAC GTG GAC CTG GAG ALG AAG GAA ACT GTC TGG CGG CTG CCT GTG TTT AGC ACA TTा AGA GBC GAT GAG GAG TTC TAC GTG GAC CTG GAG ARG ALG GAA ACT GTC TGG CGG CTG CCT GTG TTा AGC ACA TTा ACA GGC GAT GAG GAG TTC TAC GTG GAC CTG GAG AAG ALG GAA ACT GTC TGG CGG CTG CCT GTG TTा AGC ACA TTा GCA GGC GAT GAG GAG TTC TAK GTG GAC CTG GLG ARG AAG GAA ACT GTC TGG CGG CTG CCT GTG TTT AGC ACA TTT AGA GSC GAT GAG GAG TTC TAC GTG GAC CTG GAG ALG ALG GAA ACT GTC TGG CGG CTG CCT GTG TTा AGC ACA TTा AGA GGC GAT GLG GAG TTC TAC GTG GAC CTG GLG ALG ARG GAA ACT GTC TGG CGG CTG CCT GTG TTT AGC ACA TTT AGA

$$
60
$$

65

70

75

80

ИGT TTT GAC CCA CLG GGT GCA CTG RGA AAC TTG GCT ATA ATA AAA CAA AAC TTG AAC ATC ATG ACT AAA LGG TCC AGT TTा GAC CCA CAG GGT GCA CTG LGA AAC TTG GCT ATA ACA AAA CAA AAC TTG AAC ATC ATG ACT AAA AGG TCC सGT TाT GAC CCA CAG GGT GCA CTG AGA AAC TTG GCC AGA GCA AAA CAA AAC TTG AAC ATC CTG ACT AAA AGT TCC AGT TTा GAC CCA CAG GGT GCA CTG AGA AAC TTG GCT ATA ATA AAA CAA AAC TTG AAC ATC CTG ACT AAA AGG TCC यदा TाT GAC CCA CAG GGT GCA CTG LGA AAC TTG GCT ATA ACA AAA CAA AAC TTG AAC ATC ATG ACT AAA AGG TCC AGT TTT GAC CCA CAG GGT GCG CTG RGA AAC TTG GCT ATA ACA AAA CAA AAC TTG AAC ATC ATG ACT AAA AGG TCC सGT TTा GAC CCA CAG GGT GCA CTG LGA AAC TTG GCT ATA ATA AAA CAA AAC TTG AAC ATC CTG ACT AAA AGG TCC AGT TTT GAC CCA CAG GGT GCA CTG AGA AAC TTG GCT ATA ACA AAA CAA AAC TTG AAC ATC ATG ACT AAA AGG TCC LGT TTा GAC CCA CAG GGT GCA CTG LGA AAC TTG GCC AGA GCA AAA CAA AAC TTG AAC ATC CTG ACT AAA AGG TCC AGT TTा GLC CCA CAG GGT GCA CTG LGA ALC TTG GCT ATA ATA AAA CAA AAC TTG AAC ATC ATG ACT AAA AGG TCC LGT TTा GAC CCA CAG GGT GCA CTG AGA AAC TTG GCT ATA GCA AAA CAA AAC TTG AAC ATC CTG ACT AAA AGT TCC AGT TTा GAC CCA CAG GGT GCA CTG AGA AAC TTG GCT ATA ATA AAA CAA AAC TTG AAC ATC ATG ACT AAA AGG TCC AGT TTT GAC CCA CAG GGT GCA CTG LGA AAC TTG GCT ATA GCA AAA CAA AAC TTG AAC ATC ATG ACT AAA AGG TCC LGT TIT GAC CCA CAG GGT GCA CTG LGA AAC TTG GCT ATA ACA AAA CAA AAC TTG AAC ATC ATG ACT AAA AGG TCC LGT TTा GAC CCA CAG GGT GCA CTG AGA AAC TTG GCT ATA ATA AAA CAA AAC TTG AAC ATC ATG ACT AAA AGG TCC LGT TTT GAC CCA CAG GGT GCA CTG LGA AAC TTG GCT ATA ATA AAA CAA AAC TTG AAC ATC ATG ACT AAA AGG TCC

85

ARC CAA ACT GCT GCT ACC AAT ARC AAA ACT GCT GCT RCC AAT AAC CAA ACT GCT GCT ACC AAT ACE CAA ACT GCT GCT RCC AAT AAC AAA ACT GCT GCT ACC AAT ARC AAA ACT GCT GCT ACC AAT AAC CAA ACT GCT GCT ACC AAT ARC CAA ACT GCT GCT RCC AAT AQC CAA ACT GCT GCT RCC AAT AAC CAA ACT GCT GCT ACC AAT AAC CAA ACT GCT GCT ACC AAT ARC AAA ACT GCT GCT RCC AAT AAC CAA ACT GCT GCT ACC AAT AAC AAA ACT GCT GCT ACC AAT AAC CAA ACT GCT GCT ACC AAT AAC CAA ACT GCT GCT ACC AAT 


\section{c) DLA-DQB1.}

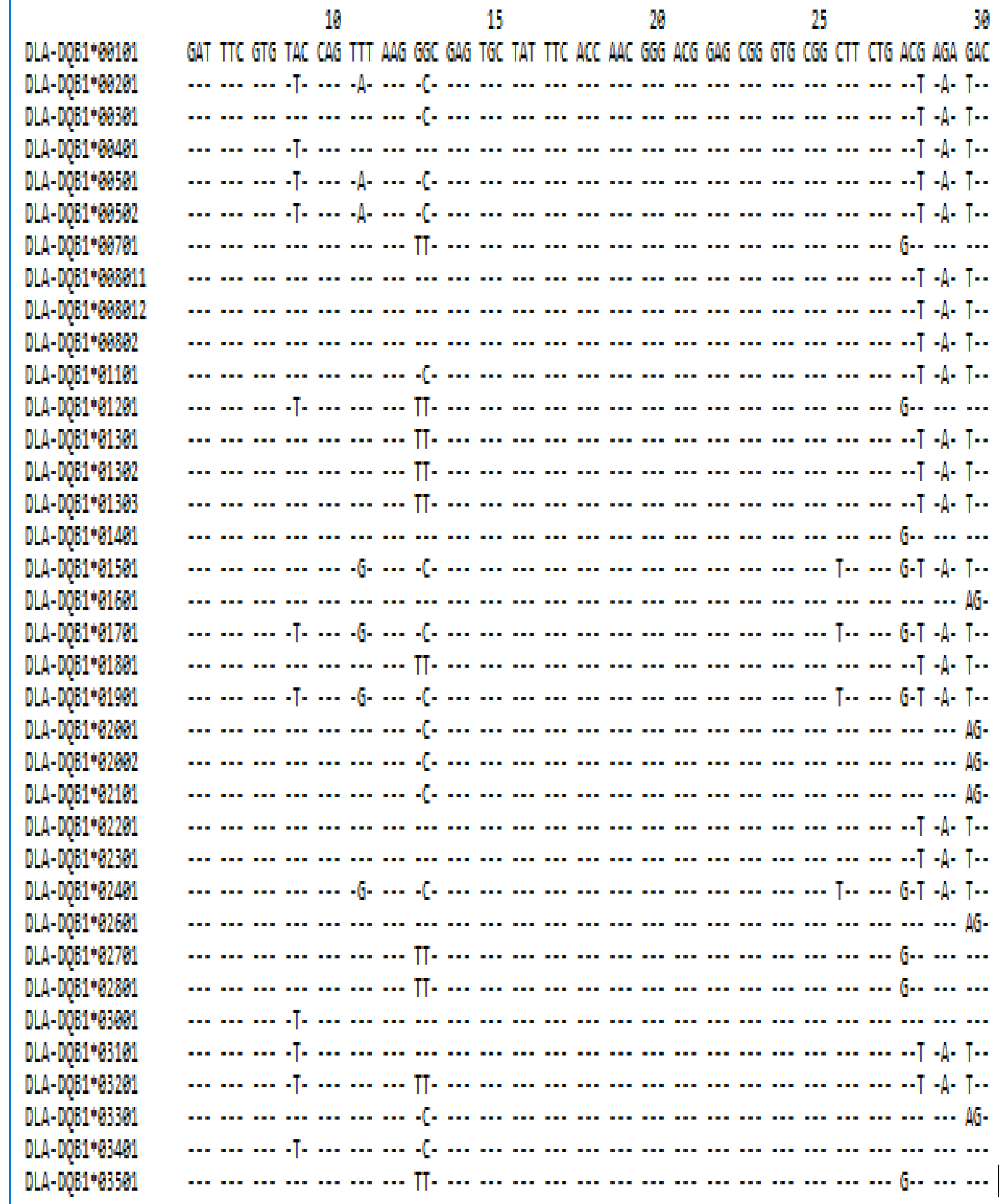


$35 \quad 46 \quad 45 \quad 50$

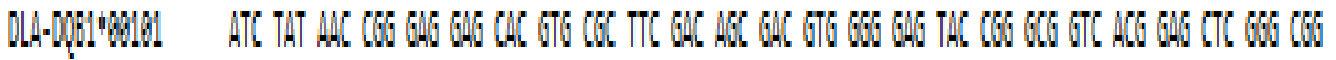

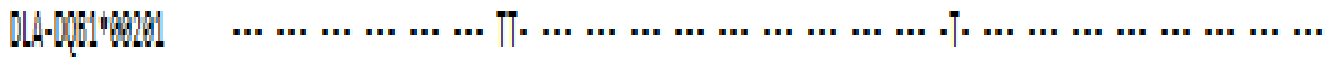

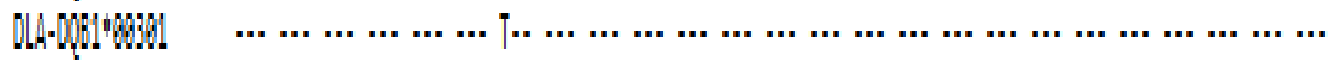

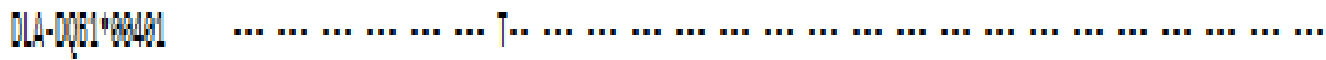

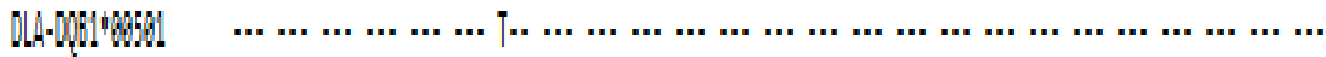

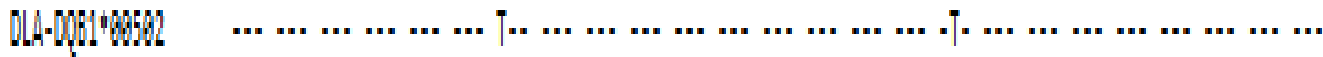

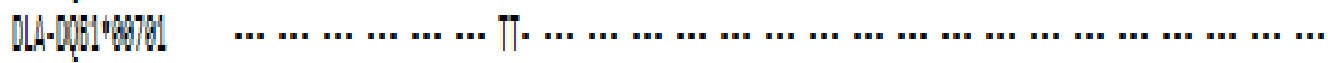

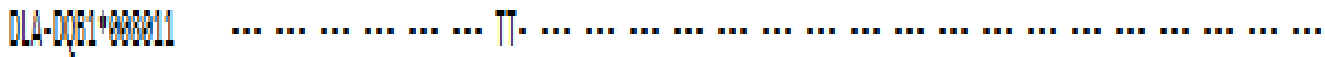

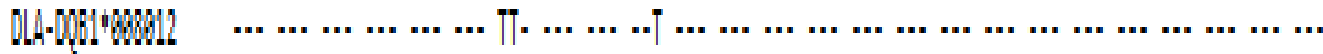

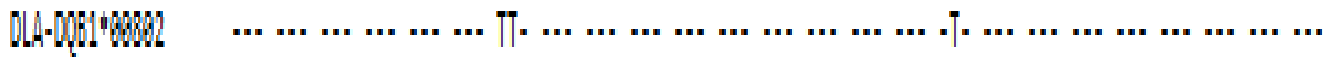

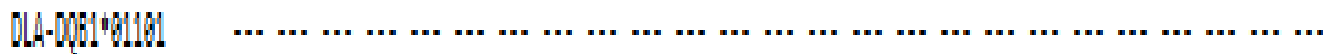

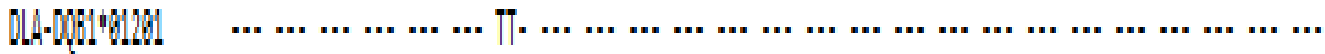

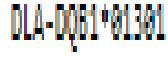

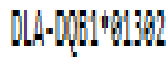
D.A.WE1:1913

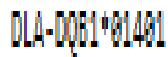
D.A.ME11915. D.A.WE1.9616. DLA.WB!1617\% D.A.WE140183. DLA.WE1191961 DLA.WE1 WOW. DLA.WB! WOW DLA.WE162018

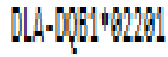

DLA.WE16281.

DLA.WE14024. DLA.WE10626.

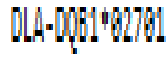

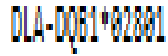

D.A.WELWWW D.A.W616819.

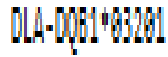

D.A.DE1"6331.

D.A.WE1.6841.

DLA.W61635.

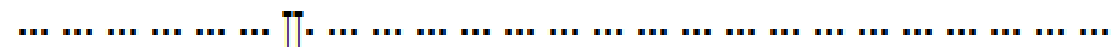

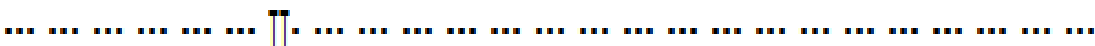

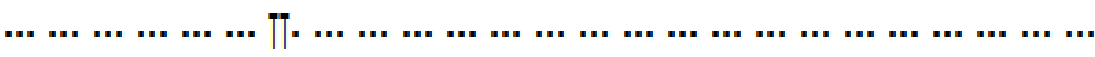

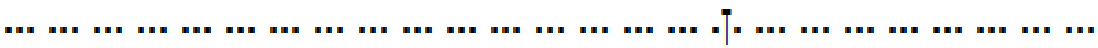

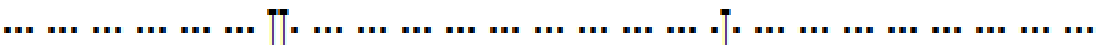

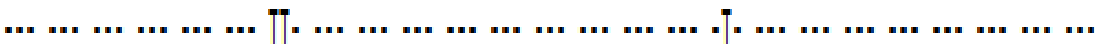

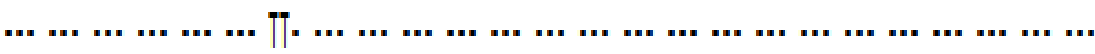

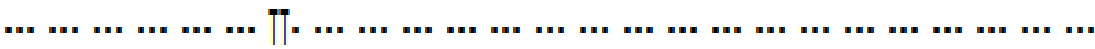

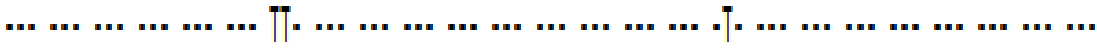

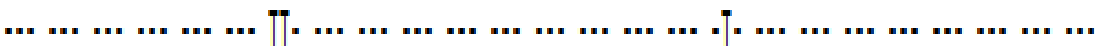

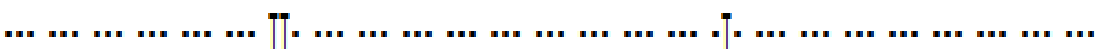

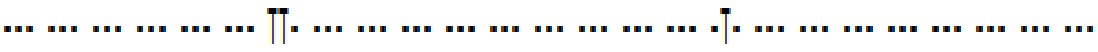

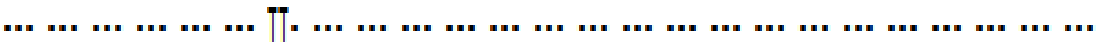

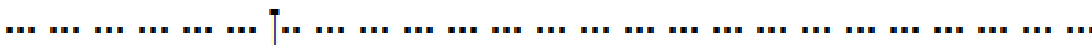

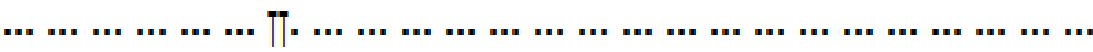

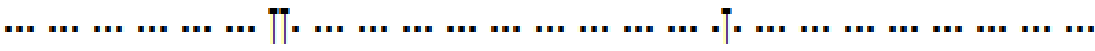

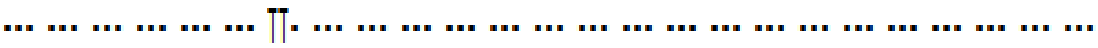

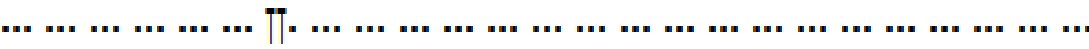
[..

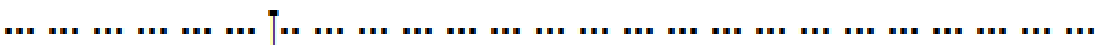

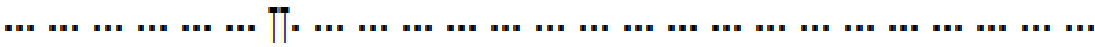

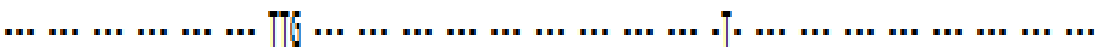
"... $\ldots$ 


\begin{tabular}{|c|c|}
\hline & 75 \\
\hline 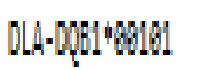 & 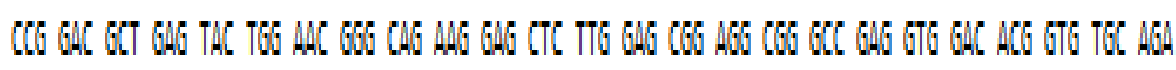 \\
\hline DLA-WWILWWI & 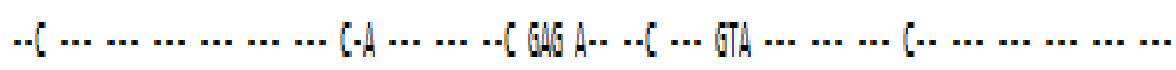 \\
\hline 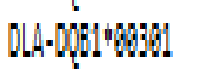 & 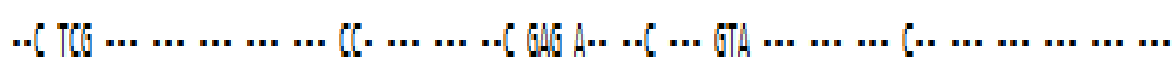 \\
\hline 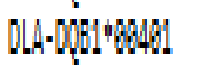 & 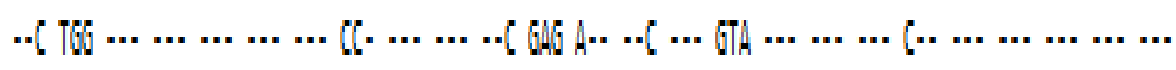 \\
\hline 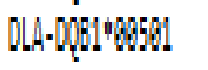 & 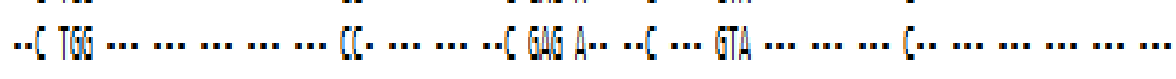 \\
\hline DLA.WB:WWW & 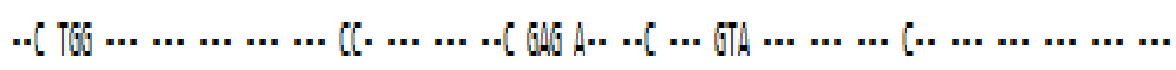 \\
\hline DLA-WB:WWM & 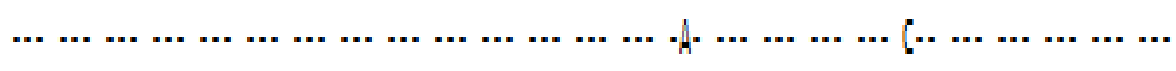 \\
\hline DLA.WB1+WW11 & 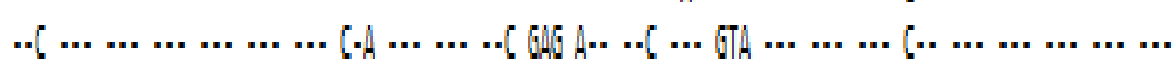 \\
\hline DLADWB'WWL2 & 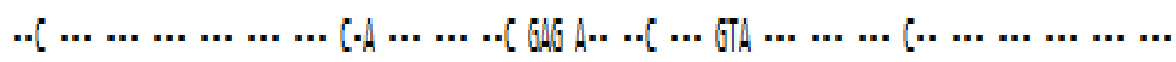 \\
\hline DLADOWILWW & 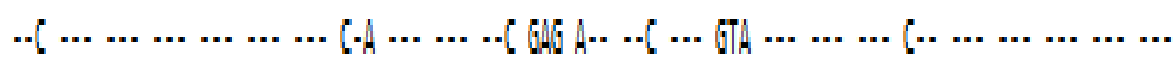 \\
\hline 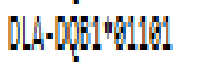 & 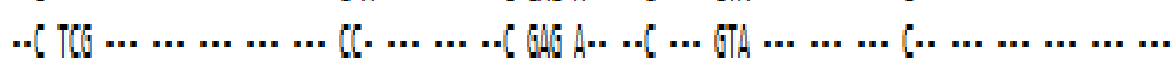 \\
\hline 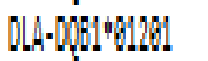 & 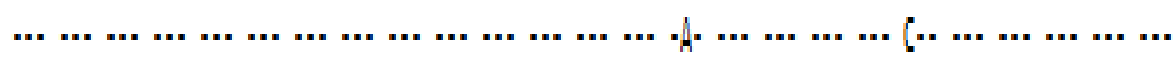 \\
\hline DLA.MB14B131 & 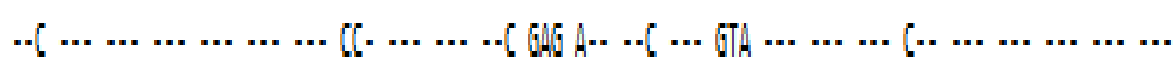 \\
\hline 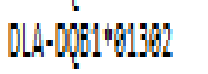 & $\cdots[\cdots \cdots \cdots \cdots \cdots$ \\
\hline 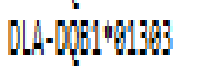 & 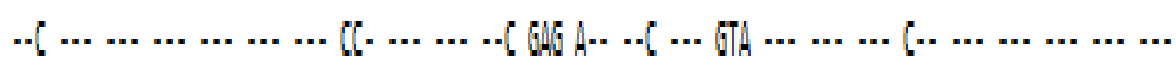 \\
\hline 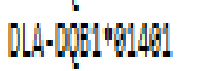 & 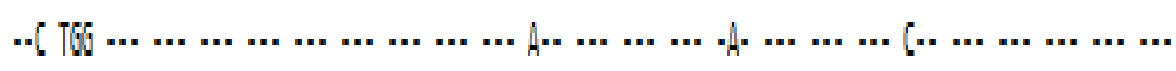 \\
\hline 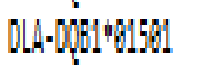 & 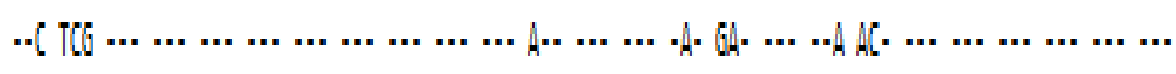 \\
\hline DLA.WBL16161 & 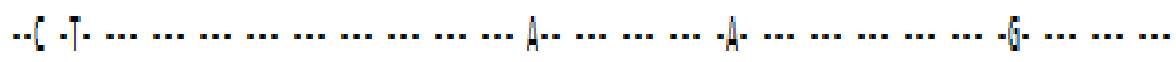 \\
\hline DLA-WB:1917M! & 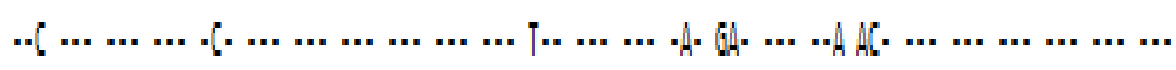 \\
\hline 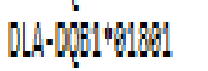 & 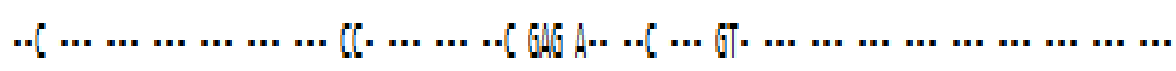 \\
\hline 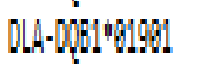 & 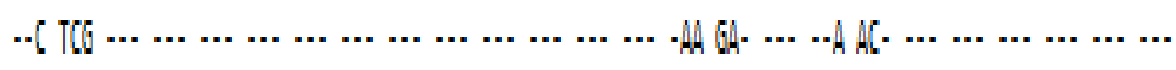 \\
\hline 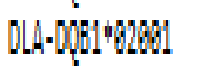 & 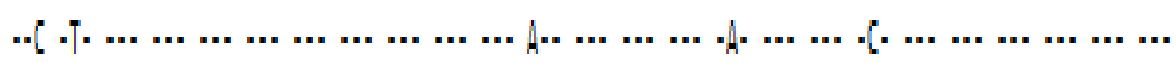 \\
\hline DLADBPOWW & 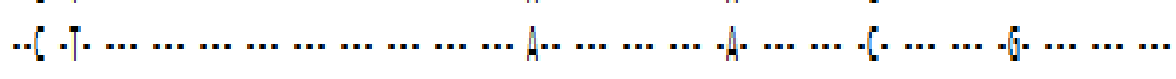 \\
\hline 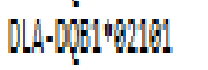 & 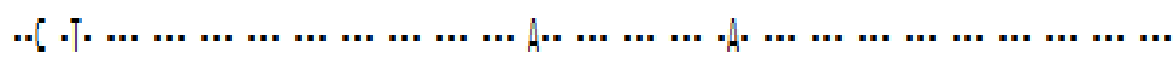 \\
\hline 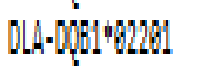 & 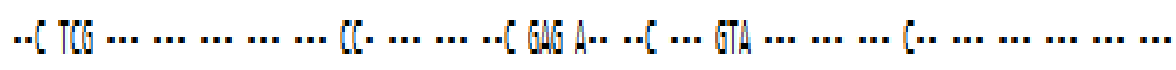 \\
\hline 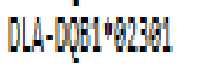 & 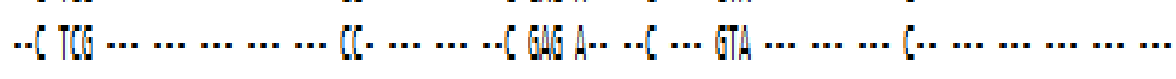 \\
\hline 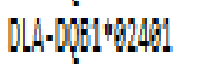 & 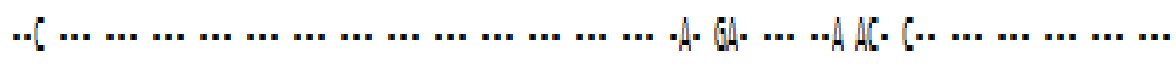 \\
\hline 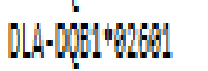 & 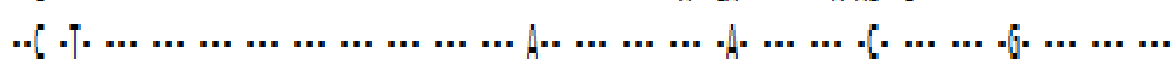 \\
\hline 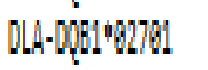 & $\cdots[\cdots \cdots \cdots \cdots \cdots$ \\
\hline 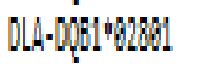 & 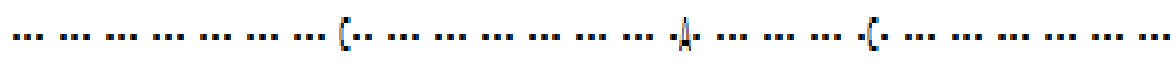 \\
\hline DLA.WOELWWI & 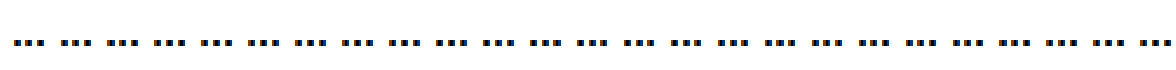 \\
\hline DLA-WB:146119! & 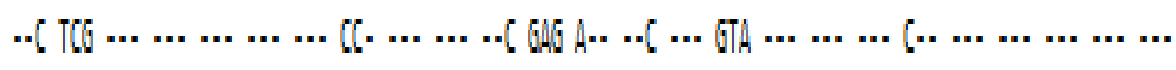 \\
\hline 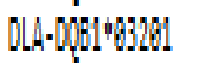 & 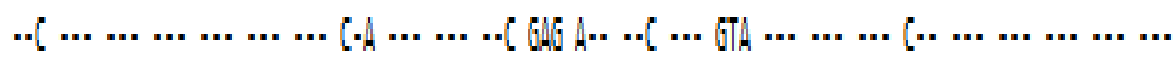 \\
\hline DLA.DB140331 & 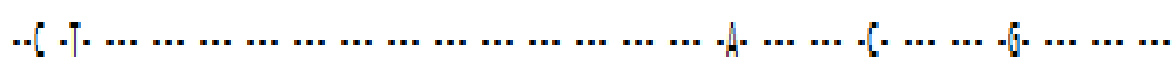 \\
\hline 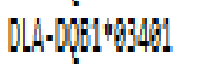 & 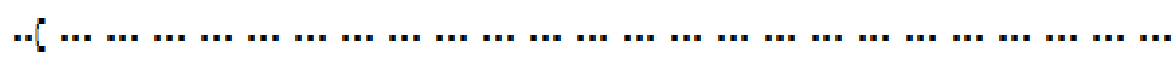 \\
\hline 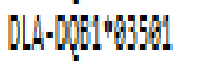 & 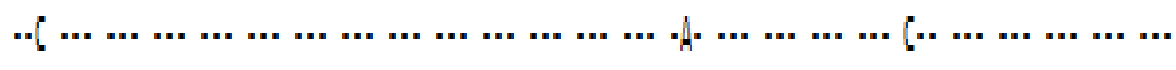 \\
\hline
\end{tabular}


85

90

DLA-DQ61"09191 CAC AAC TAC G66 A66 GA4 GAG CTC ACC ACG TTG CAG C66 CGA DLA-DQB1+6201

DLA-DQB1"69391

DLA-DQB1"60491

DLA-DQ61"09591

DLA-DQB1"69592

DLA-DQB1"60761

DLA-DQ81"606011

DLA-DQB1"608012

DLA-DQB1+6062

DLA-DQB1"61191

DLA-DQ61"01201

DLA-DQB1"61391

DLA-DQB1"61392

DLA-DQB1"61393

DLA-DQE1"01491

DLA-DQB1"61591

DLA-DQ81"01601

DLA-DQB1"61701

DLA-DQB1"61891

DLA-DQB1"61901

DLA-DQB1"02081

DLA-DQ81"02692

DLA-DQB1"02191

DLA-DQB1"02261

DLA-DQB1"02391

DLA-DQ61"02491

DLA-DQB1"62691

DLA-DQB1"02701

DLA-DQB1"02801

DLA-DQ61"63091

DLA-DQB1"63191

DLA-DQB1"03261

DLA-DQ61"63391

DLA-DQB1"03491

DLA-DQB1"63591

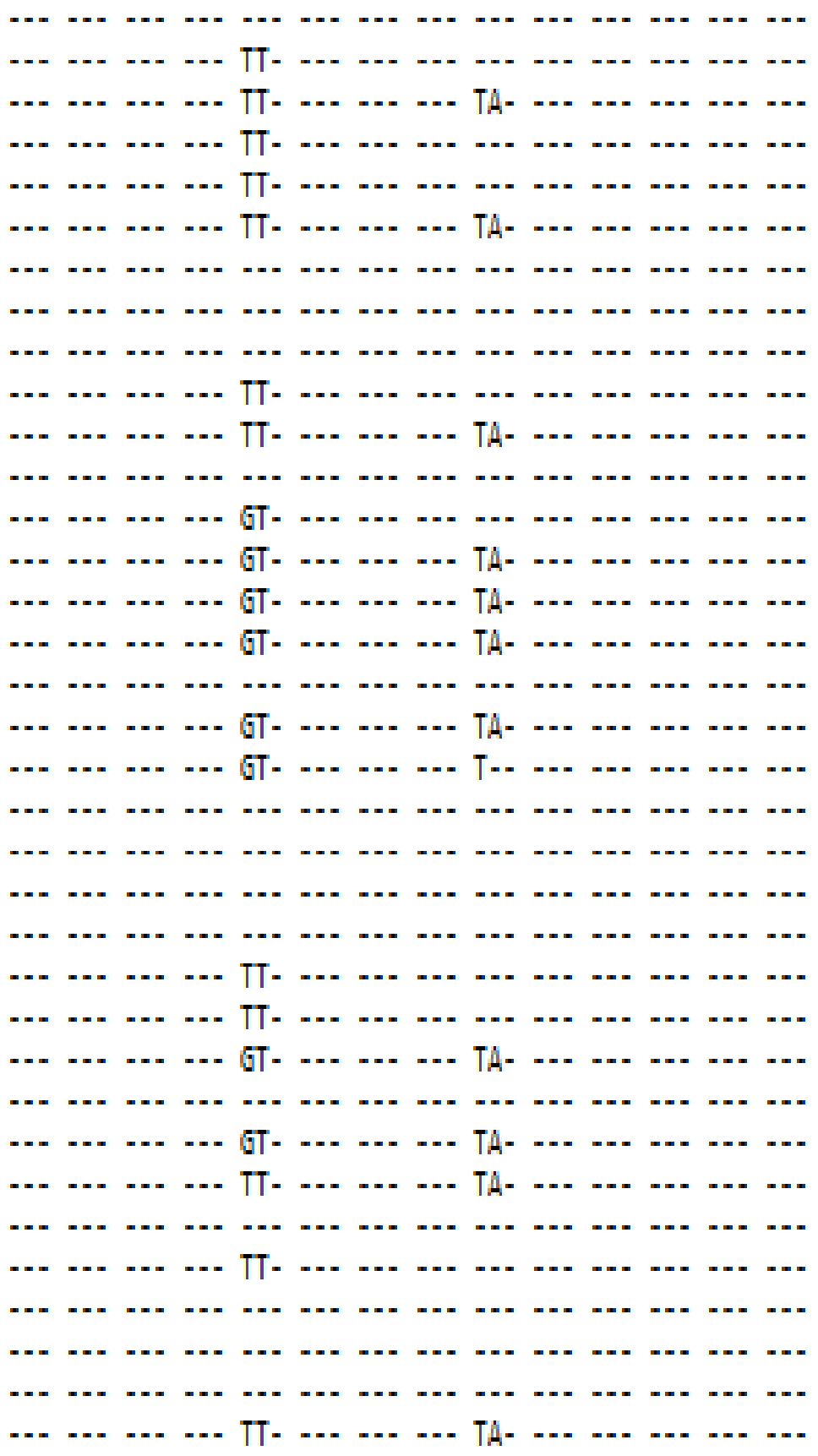

